\title{
Toward Unlocking Lockups
}

\author{
Stephen Fraidin ${ }^{\dagger} \&$ Jon D. Hanson ${ }^{\dagger \dagger}$
}

\section{CONTENTS}

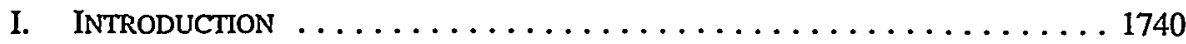

II. Current Views of Lockups . . . . . . . . . . . . . . . . . . . . . 1745

A. A Taxonomy . . . . . . . . . . . . . . . . . . . 1745

B. The Ex Ante Approach . . . . . . . . . . . . . . . . . 1748

1. Delaware's Purported Ex Ante Standard . . . . . . . . . . 1748

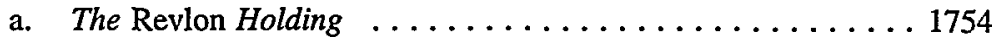

b. The Paramount II Holding . . . . . . . . . . . . . . 1757

2. Delaware's De Facto Relevance Rule . . . . . . . . . . 1765

C. The Ex Post Approach ....................... 1766

1. Stephen Bainbridge's Ex Post Approach . . . . . . . . . 1767

2. Ian Ayres' Ex Post Approach . . . . . . . . . . . . . . . 1769

3. Can Foreclosing Lockups Be Loyal? . . . . . . . . . . . . 1779

III. A NEW VIEW of LockuPS $\ldots \ldots \ldots \ldots \ldots \ldots \ldots \ldots \ldots \ldots \ldots \ldots \ldots$

A. Can Lockups Be Foreclosing? . . . . . . . . . . . . . . . 1784

1. A Target Board's Unwillingness To Foreclose

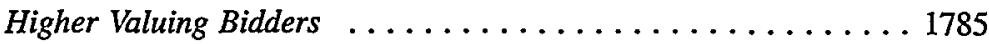

2. A Target Board's Inability To Foreclose Higher Valuing Bidders . . 1788

a. The Transactions Costs of Resales . . . . . . . . . . 1790

b. The Transactions Costs of Pre-Sales . . . . . . . . . . 1794

c. The Possibility of Reputational Foreclosure . . . . . . . . 1795

3. Summary ......................... 1801

B. Maximizing Target Shareholder Returns . . . . . . . . . . . . . 1804

$\dagger$ Partner, Fried, Frank, Harris, Shriver \& Jacobson, New York; Visiting Lecturer, Yale Law School.

†† Assistant Professor, Harvard Law School.

We are indebted to Ian Ayres, Lucian Bebchuk, Bob Clark, Steve Croley, Rob Daines, Howell Jackson, Louis Kaplow, Reinier Kraakman, Larry Kramer, Kyle Logue, Steven Shavell, and participants in the Law and Economics Workshop at Harvard Law School, for helpful comments on prior versions of this Article, to Ben Clark, Alicia Curry, John Dellaportas, Caroline Gentile, Daryl Joseffer, and Kevin Warsh for excellent research assistance, and to Maritza Fernandez and Carol Igoe for diligent secretarial assistance. For financial support we are grateful also to Fried, Frank, Harris, Shriver \& Jacobson and the Harvard Law School Facuity Summer Research Program. Very special thanks go to Kathleen and Emily Hanson. 
1. Management's Incentive To Maximize Share Price . . . . . . . 1804

2. Can Nonforeclosing Lockups Be Disloyal? ............. 1806

C. The Benefits of Lockups . . . . . . . . . . . . . . . . 1812

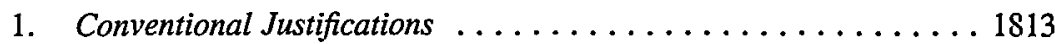

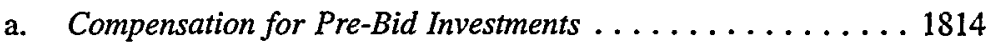

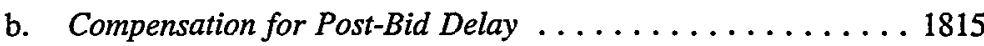

i. $\quad$ Target-Created Delay . . . . . . . . . . . . 1815

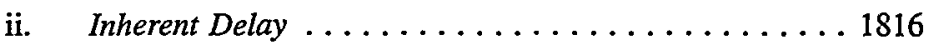

c. Compensation for Target Breach . . . . . . . . . . 1817

2. Maximizing Joint Gains To Trade ............... 1822

a. Differing Estimates of Auction Outcome . . . . . . . 1822

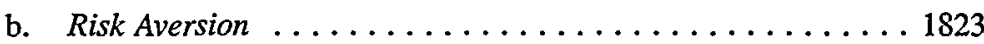

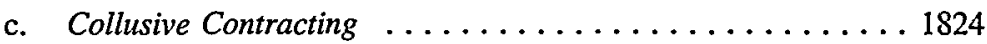

d. Encouraging Search .................. 1826

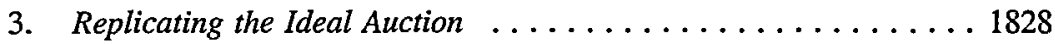

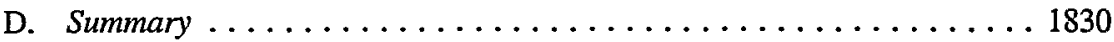

IV. Conclusion $\ldots \ldots \ldots \ldots \ldots \ldots \ldots \ldots \ldots \ldots \ldots \ldots \ldots \ldots \ldots \ldots \ldots \ldots \ldots$

\section{INTRODUCTION}

According to conventional wisdom, target boards face a powerful and unavoidable conflict of interest when deciding how to respond to a hostile bid: ${ }^{1}$ Because takeovers threaten the jobs of target directors and officers, ${ }^{2}$

1. See RoBERT C. CLARK, CORPORATE LAW 588-89 (1986) ("[W]e could well conclude that in no other context is the conflict of interest as serious as in the takeover situation. Often the managers' jobs are at stake."); Stephen M. Bainbridge, Exclusive Merger Agreements and Lock-Ups in Negotiated Corporate Acquisitions, 75 MINN. L. REv. 239, 272-73 (1990) ("Inherent in all corporate acquisitions is a potential conflict between the interests of target managers and the interests of shareholders. This tension is perhaps most obvious in hostile takeovers. If the bidder is successful, many target directors and officers will almost certainly lose their positions. On the other hand, if incumbent management defeats the bidder, target directors and officers will retain their positions, but target shareholders will lose a substantial premium for their shares. Any action by management in a hostile takeover situation, except pure passivity, is thus tainted by the specter of self-interest."); Ronald J. Gilson, A Structural Approach to Corporations: The Case Against Defensive Tactics in Tender Offers, 33 STAN. L. REV. 819, 819 (1981) " Tender offers present an obvious and inherent conflict of interest between management and shareholders."); id. at 820 ("Courts and regulatory authorities have long recognized this conflict between management's wish to retain control and the shareholders' wish to have access to the highest price for their stock."); Jennifer J. Johnson \& Mary Siegel, Corporate Mergers: Redefining the Role of Target Directors, 136 U. PA. L. REV. 315, 324 (1987) (corporate control transactions "present inside target directors with an unavoidable conflict of interest"); id. at 325 "The inevitability of the conflict of interest inherent in corporate control transactions makes it inappropriate to presume, as does the business judgment rule, that the inside directors have fulfilled their duty of loyalty."); Bennett v. Propp, 187 A.2d 405, 409 (Del. 1962) ("The directors are of necessity confronted with a conflict of interest, and an objective decision is difficult."); cf. Frank H. Easterbrook \& Daniel R. Fischel, The Proper Role of a Target's Managentent in Responding to a Tender Offer, 94 HARV. L. REv. 1161, 1194-1204 (1981) (rejecting business judgment rule for reviewing directors' inherent confict of interest).

2. We will use the terms "target management" and "target board" interchangeably on the assumption that the presence of outside, so-called independent, directors on a target board does not significantly affect 
target boards are thought to have an incentive either to defeat all bidders or to conspire with a particular bidder. If the target board pursues either of those strategies, target shareholders stand to lose all or some portion of a substantial takeover premium for their shares. ${ }^{3}$ As Professor Gilson explains, "it is impossible to identify ... any path management might take which would eliminate the inherent conflict of interest, and action, whether criticism or approval, reflects the potential for diversion of benefit to management and away from shareholders."

Delaware courts have responded asymmetrically to this inherent conflict of interest. On one hand, they have shown near limitless deference to target boards (and thus little concern for the conflict of interest), provided the boards reject all bidders. ${ }^{5}$ As corporate commentators sometimes quip, target boards are permitted to "just say no." On the other hand, once a board decides to sell its firm, courts often intervene to prevent the board from giving any one bidder undue advantage over other actual or potential bidders. ${ }^{7}$ The goal is to

a target management's ability to attain its self-interested goals. See Dynamics Corp. of Am. v. CTS Corp., 794 F.2d 250, 256 (7th Cir. 1986), rev'd on other grounds, 481 U.S. 69 (1987); Bainbridge, supra note 1, at 276-79; Panter v. Marshall Fields \& Co., 681 F.2d 271 (7th Cir. 1981); Peter Cramton \& Alan Schwartz, Using Auction Theory To Inform Takeover Regulation, 7 J.L. ECON. \& ORG. 27, 48 (1991); William T. Allen, Independent Directors in MBO Transactions: Are They Fact or Fantasy?, 45 Bus. LAw. 2055 (1990).

In recent years, however, this assumption has been called into question. Independent directors increasingly function as aggressive monitors of management and have forced out the CEO's of such Fortune 500 companies as IBM, General Motors, Westinghouse, and Eastman Kodak. See Martha S. Klein \& Susan Beck, Shaking Up the Boardroom, AM. LAw., Apr. 1993, Supp: Corporate Scorecard, at 6; Nikki Tait, Whitmore Resigns as Kodak Chief, FIN. TIMES, Aug. 7, 1993, at 10. Of late, institutional investors and corporate commentators have looked to independent board members to provide an even greater oversight mechanism of corporate policy and performance. See, e.g., Martin Lipton \& Jay W. Lorsch, A Modest Proposal for Improved Corporate Governance, 48 BUS. LAW. 59 (1992); Nell Minow, Revolt of the Corporate Boards, LEGAL TIMES, May 18, 1992, at 22.

3. See infra note 142 (describing magnitude of average takeover premiums); see also Gilson, supra note 1 , at 819 ("On the one hand, an offer provides shareholders with the opportunity to sell their shares for a substantial premium over market price. On the other hand, the tender offer is the principal mechanism by which management can be forcibly unseated from control.").

4. Gilson, supra note 1 , at 826.

5. See, e.g., Paramount Communications, Inc. v. Time Inc., 571 A.2d 1140 (Del. 1990); Pogostin v. Rice, 480 A.2d 619, 627 (Del. 1984); see Paramount Communications, Inc. v. QVC Network, Inc., 1994 WL 30181, at *21 n.13 (Del. Feb. 4, 1994) ("[W] here a potential sale of control by a corporation is not the consequence of a board's action, this Court has recognized the prerogative of a board of directors to resist a third party's unsolicited acquisition or offer."); FRANK H. EASTERBROOK \& DANIEL R. FISCHEL, THE ECONOMIC STRUCTURE OF CORPORATE LAW 164-65 (1991); cf. Joseph A. Grundfest, Just Vote No: A Minimalist Strategy for Dealing with Barbarians Inside the Gates, 45 STAN. L. REv. 857, 858 n.4 (1993) (describing the deterrence effect Delaware's deference has had on hostile takeover activity).

6. See, e.g., John C. Coffee, Jr., Defining 'Sale' Is Paramount Concern, NAT'L L.J., Nov. 8, 1993, at 18; Ronald J, Gilson, Just Say No to Whom?, 25 WAKE ForEST L. REV. 121 (1990); Jeffrey N. Gordon, Corporations, Markets, and Courts, 91 CoLUM. L. REV. 1931, 1932 (1991).

7. See Revlon, Inc. v. MacAndrews \& Forbes Holdings, Inc., 506 A.2d 173 (Del. 1986); Mills Acquisition Co. v. Macmillan, Inc., 559 A.2d 1261, 1287 (Del. 1988); Barkan v. Amsted Indus., Inc., 567 A.2d 1279, 1286 (Del. 1989); see also Cede \& Co. v. Technicolor, Nos. 336 \& 337, 1993 Del. LEXIS 398 (Del. Oct. 22, 1993) (a board that does not give fair consideration to all potential bidders may have to pay damages to shareholders even if the ultimate sale price is greater than the assessed valuation of the target); EASTERBROOK \& FISCHEL, supra note 5, at 165. 
foster a robust takeover auction on the theory that competitive bidding best protects the interests of target shareholders.

Consistent with that goal, courts have been especially suspicious of lockups. . A "lockup," loosely defined, is a target board's promise to compensate a bidder a specified amount if the target breaches or does not consummate its merger agreement with the bidder. Because cooperation from the target board can be valuable to would-be acquirers, a bidder might be willing to offer target management a side payment-that is, job security-in exchange for the board's cooperation.' Conventional wisdom has it that lockups are the means by which target boards simultaneously give an advantage to a favored bidder and protect any side payments received in return. $^{10}$ According to this widely held view, lockups serve target managements who, in exchange for job security and at the expense of target shareholders, accept a lower premium than would prevail had they sought

8. For a description of the various types of arrangements that courts regard as lockups, see infra notes 22-24 and accompanying text.

9. See ClARK, supra note 1, at 465-66; Ian Ayres, Analyzing Stock Lock-Ups: Do Target Treasury Sales Foreclose or Facilitate Takeover Auctions?, 90 CoLUM. L. REv. 682,699 (1990) ("Although target managers might enter into treasury share [i.e., lockup] agreements to further their shareholders' interests, it also is possible that target managers will sell treasury shares solely to promote their own interests in retaining their jobs. If the target managers are unfaithful agents, they may choose to sell treasury shares to a bidder who implicitly promises to retain their services."); Lucian A. Bebchuk, The Case for Facilitating Competing Tender Offers: A Reply and Extension, 35 STAN. L. REV. 23, 25 n.8 (1982) ("In pursuing a negotiated sale, management might be concerned not only with the shareholders' interests but also with its own, different objectives. Management might choose as an acquisition partner not the company that values the target's assets most highly, but rather another company that is more likely to retain the management or present it with substantial personal benefits. ... [and] might approve in return for personal benefits a much smaller acquisition price than other potential buyers would be willing to pay."); Frank H. Easterbrook \& Daniel R. Fischel, Auctions and Sunk Costs in Tender Offers, 35 STAN. L. REv. 1, 1 (1982) ("In most cases resistance [to takeover bids] reflects either mismanagement (to the extent it pointlessly denies shareholders the opportunity to obtain a premium) or manager's self-protection (to the extent its point is to preserve managers' jobs or 'sell' their acquiescence in exchange for bonuses or promises of future employment)."); Johnson \& Siegel, supra note 1, at 318 ("A completed merger necessitates the disappearance of the target corporation as an autonomous entity with the concomitant loss of control and job security for target managers. To counter these concerns, a bidder may offer target managers lucrative employment contracts or other incentives designed to secure their cooperation. Inside target managers may thus accept or reject a merger proposal for personal reasons without giving proper consideration to the best interests of their shareholders."); id. at 324-25 ("On one hand, the inside target directors may be motivated to reject an offer because of personal financial reasons, job security concerns, or a desire to maintain the power and prestige deriving from their positions of control. Bidders, on the other hand, recognizing these concerns and the importance of securing the cooperation of target management, may provide incentives to elicit target management's approval.").

10. Not surprisingly, many corporate scholars have expressed grave doubts about the loyalty of lockups. See, e.g., CLARK, supra note 1, at 573 ("During a bidding war, of course, the shareholders would not approve any [lockup], but would prefer a free and unhampered auction for their shares."); Bebchuk, supra note 9, at 47 ("All the participants in this exchange agree that obstructive defense tactics [such as lockup arrangements with a white knight] should be prohibited . . . ."); Lucian A. Bebchuk, The Case for Facilitating Competing Tender Offers: A Last (?) Reply, 2 J.L. ECON. \& ORG. 253, 254 (1986) (substantially the same); Easterbrook \& Fischel, supra note 9, at $15 \mathrm{n.32}$ (explaining that Bebchuk and Gilson would not allow lockups because it makes the auction process non-neutral); Alan Schwartz, Search Theory and the Tender Offer Auction, 2 J.L. ECON \& ORG. 229, 238 (1986) (Schwartz's normative analysis "implies a prohibition of 'lockups"'). 
simply to sell to the highest valuing bidder on the best possible terms. ${ }^{11}$ For those reasons, Delaware courts do not permit a corporate board that has decided to sell the corporation to favor one potential buyer over another. ${ }^{2}$ Put differently, corporate boards cannot "just say yes." Pertinent Delaware takeover laws can thus be summarized with two simple rules: (1) a target board can just say no to any bidder so long as it says no to all potential bidders; (2) if, however, the target board does not reject all bidders, it cannot say yes to just one bidder. ${ }^{13}$

Efficiency-minded corporate law scholars have responded more symmetrically to the inherent conflict of interest. Most agree that target boards should be prohibited from seriously obstructing any tender offer, either by rejecting all potential bidders-through, say, a poison pill—or by rejecting all but one potential bidder through a lockup. According to this widely held view, target managements will, if permitted, use those defensive tactics to protect their jobs, and thus will obstruct the transfer of corporate assets to their highest valued use (that is, obstruct the goal of allocative efficiency). Consistent with that viewpoint, most corporate law scholars call for the abolition of virtually all takeover defenses (lockups included), criticizing Delaware's first rule regarding takeovers, but endorsing its second.

It seems fair to say, therefore, that most corporate law scholars and courts agree that some lockups should be invalidated as contrary to the interests of target shareholders and/or the goal of allocational efficiency. In contrast, this Article defends the extreme position that all lockups should be enforced, subject only to the business judgment rule. ${ }^{14}$ The body of this Article is broken into two broad sections. Part II accepts as true the heretofore uncontested premise that some lockups should be invalidated, and argues that no sound practical method exists for distinguishing undesirable from desirable

11. See also Ayres, supra note 9, at 684 ("foreclosure represents an agency cost in which target management places its own interests in incumbency before the shareholders' interest in maximizing share value"); Bainbridge, supra note 1, at 249 ("To obtain the board's cooperation, the bidder may offer management side payments, such as employment contracts containing enhanced benefits. In return, management may take action contrary to the shareholders' best interests, such as agreeing to an acquisition price below the price management could obtain through arms-length bargaining.").

12. See, e.g., Revlon, Inc. v. MacAndrews \& Forbes Holdings, Inc., 506 A.2d 173, 180 (Del. 1986) ("Selective dealings to fend off a hostile ... bidder [is not] a proper objective"); $i d$. at 184 (target boards cannot "play[] favorites" among "contending factions"); Samjens Partners I v. Burlington Indus., Inc., 663 F. Supp. 614, 624 (S.D.N.Y. 1987) (A target board "cannot deal selectively to fend off a hostile bidder.").

13. The Delaware laws can be synthesized into a single rule that target boards must treat all potential bidders equally: either all bidders must be ignored or all bidders must be granted equal attention. Lockups, unlike pure defense strategies or open auctions, violate that rule by giving advantage to one bidder. Although we believe this single rule fairly characterizes actual Delaware case law, it slightly mischaracterizes the reasoning offered in some Delaware decisions. As explained below, Delaware courts purport to enforce any lockups that are in the interest of target shareholders. See infra Part II.B; see, e.g., In re J.P. Stevens, Co., Inc., 542 A.2d 770, 782 (Del. Ch. 1988) (explaining that board may favor one bidder over others "if, but only if, it is in the shareholders" interest to do so"); accord QVC Network, Inc. v. Paramount Communications Inc., 635 A.2d 1245 (Del. Ch. 1993).

14. See infra note 48 (defining business judgment rule). 
lockups. Part III rejects that premise and makes a case for enforcing virtually all lockups.

More specifically, Part II describes and criticizes both the approach that courts have generally taken and an alternative approach that scholars have advanced for evaluating the net effect of lockups. Part II.B explains that Delaware courts purport to examine lockups from the perspective of target shareholders, asking whether the shareholders were better off immediately before or immediately after the lockup was granted. We argue that the openended "proportionality standard" that courts apply to make that assessment is without content and that courts have-perhaps because of the insuperable obstacles confronting them-adopted a clear-cut de facto rule which is equivalent in its effect to a rule that would invalidate all lockups.

Part II.C examines two recent proposals for replacing judicial substantive analysis with a kind of market-based test of lockups. Instead of weighing the benefits and costs of a lockup from the shareholders' perspective, courts should, according to these proposals, take an "ex post" or "bidder" perspective and enforce only those lockups that do not unduly deter or "foreclose" potential bidders from competing. The courts' only task would be to distinguish foreclosing from nonforeclosing lockups. Stephen Bainbridge proposes a "bright-line" version of this approach, recommending that courts enjoin any lockup that guarantees the recipient more than ten percent of the value of its bid. Ian Ayres endorses a more sophisticated version of the ex post approach, explaining that even some sizeable lockups can be nonforeclosing if they do not change the relative valuations of bidders. Both proposals are subject to numerous related criticisms, not least of which is that neither can deliver on its promise to provide courts a new means of identifying undesirable lockups. In short, Part II argues that courts are simply not capable of identifying and validating only those lockups that should be validated.

In Part III, we critically examine the animating assumption of courts and scholars-that lockups can have undesirable consequences--and make a case for enforcing all lockups. Part III.A argues that lockups are unlikely to foreclose the highest valuing bidder from acquiring the target corporation because target boards are neither eager nor able to foreclose higher valuing bidders. Our analysis replicates the basic lesson of the Coase theorem, pointing out that if transactions costs are not prohibitively high, corporate assets will wind up in their highest valued use, lockups notwithstanding. Part III.A.2 then argues that this is one context in which the Coase theorem's zero-transaction-cost assumption is not intolerably heroic. While Part III.A suggests that lockups pose little or no threat to the goal of allocative efficiency, Part III.B argues that lockups do not imperil the judicial aim of maximizing target shareholder returns. Thus, Parts III.A and III.B are intended to rebut the conventional view that lockups pose a powerful threat to the (potentially conflicting) goals of efficiency and revenue maximization. Part III.C then shifts the emphasis of 
analysis and makes an affirmative case for lockups. Although the conventional justifications for lockups are more or less underdeveloped and unpersuasive, there are a variety of ways in which lockups can increase target shareholder revenues, either by enlarging the overall size of the gains to trade between the target and the lockup recipient or by increasing the target's share of those gains.

The Article concludes by arguing that because lockups, like chicken soup, ${ }^{15}$ can't hurt but may well help, courts should move toward unlocking lockups.

\section{CURRENT VIEWS OF LOCKUPS}

\section{A. A Taxonomy}

Courts and legal scholars universally agree that some lockups should be validated, while others should be invalidated. The trick, it seems, is to distinguish one type from the other. To make that distinction, courts and scholars assess lockups from either of two general perspectives.

Courts typically enforce lockups that they conclude are loyal to the interests of target shareholders. To assess a lockup's loyalty, courts in effect ask whether, as compared to the time just prior to the granting of the lockup, the lockup made target shareholders better off. The goal of this approach is to ensure that, from an ex ante perspective, a target board does not give away more in granting a lockup than target shareholders gain from the bid offered in exchange. We shall call this the ex ante or shareholder perspective. From the shareholder perspective, there are two relevant types of lockups: (1) compensatory or loyal lockups make target shareholders at least as well off as they would have been absent the lockup, and (2) supracompensatory or disloyal lockups guarantee the recipient excessive damages and thus make target shareholders worse off ex ante. ${ }^{16}$ We analyze and critique the ex ante approach in Section B of this Part.

Recently, corporate law scholars have recommended that courts examine a lockup's effect after it is granted on the values the recipient bidder and

15. Cf. Grundfest, supra note 5 , at 868 \& n.40 (employing, and attributing to Chancellor William T. Allen, this homey simile).

16. Because the concern with lockups is that target boards will use them in a way that runs counter to the interests of target shareholders, there is no need to distinguish subcompensatory lockups from the larger set of compensatory lockups. Our use of the terms "compensatory" and "loyal" as synonyms may need some clarification. It is, of course, possible that a lockup intended to serve managerial interests at the expense of shareholders actually has a beneficial effect on shareholder interests or, aiternatively, that a lockup intended to serve shareholder interests fails to do so from an ex ante perspective. Nevertheless, we assume throughout the Article that a loyal board will grant only compensatory lockups. Although loyal boards may sometimes inadvertently grant supracompensatory lockups, our assumption can be justified on the ground that courts are in no position-and, therefore, typically do not-second guess the decisions of loyal boards. Cf. infra text accompanying note 20 . 
potential third-party bidders ascribe to the target. ${ }^{17}$ This ex post or bidder perspective attempts to render judicial intervention unnecessary by exposing disloyal target boards to the discipline of the takeover market. ${ }^{18}$ The ex post approach is based on the insight that a lockup that allows higher valuing bidders to compete for the target-that is, a nonforeclosing lockup-cannot shield any disloyal arrangement the target board may have with the recipient bidder. ${ }^{19}$ Ian Ayres summarizes the argument as follows:

Target managers do not have a conflict of interest in making such imprudent, but nonforeclosing, treasury agreements because such agreements will not prevent a higher valuing third party from outbidding the treasury share recipient. Imprudent, but nonforeclosing, treasury agreements accordingly are poor methods for entrenching incumbent target managers. The absence of this competing managerial interest militates in favor of the less stringent scrutiny that is generally applied to managerial decisions-the business judgment rule. ${ }^{20}$

In the market for corporate control, a target board can shield a disloyal arrangement with the recipient bidder from the discipline of the market only if a lockup forecloses higher valuing bidders from pursuing the target. ${ }^{21}$ From

17. See, e.g., Ayres, supra note 9; Bainbridge, supra note 1. Previous scholarship focusing on lockups primarily attempted to assimilate "what the frenzied, often dizzying and breath-taking, pace of dealmaking the 1980s produced." Roberta Romano, A Guide to Takeovers: Theory, Evidence, and Regulation, 9 YALE J. REG. 119, 121 (1992); see, e.g., Leo Herzel et al., Misunderstanding Lockups, 14 SEC. REG. L.J. 150, 177 (1986); Kenneth J. Nachbar, Revlon, Inc. v. MacAndrews \& Forbes Holdings, Inc.-The Requirement of a Level Playing Field in Contested Mergers, and Its Effect on Lock-Ups and Other Bidding Deterrents, 12 DEL. J. CORP. L. 473 (1987); James A. Wachta, Note, Down but Not Out-The Lock-Up Option Still Has Legal Punch When Properly Used, 43 WASH. \& LEE L. REV. 1125 (1986); Note, Lock-Up Options: Toward a State Law Standard, 96 HARv. L. Rev. 1068 (1983) [hereinafter Note, Lock-Up Options].

18. See generally infra Part II.C.

19. See, e.g., Bainbridge, supra note 1 , at 251 ("[M]aintaining a viable threat of competitive bidding .. provides the best available check on the conflict of interest inherent in a board's decision to approve a favored bidder's acquisition proposal."); see also id. at $249,272,275$; cf. Gilson, supra note 1, at 876 ("[I]s the potential for ... . [tender offers] which constrains self-interested behavior by management ....").

While proponents of the ex post approach believe that their proposed rule would prevent target boards from behaving disloyally, there may be some circumstances when there is no threat of a higher valuing bidder, in which case target boards would be able to grant a supracompensatory lockup with impunity under an ex post approach. See infra Part III.B.2. Nevertheless, an ex post approach will in all circumstances yield allocational efficiency. See infra Parts III.A and III.B.

20. Ayres, supra note 9, at 707 (footnotes omitted); see also Bainbridge, supra note 1, at 251 ("[T] he validity of . . lock-ups should turn on whether a given provision deters competing bids. ... [M]aintaining a viable threat of competitive bidding-an 'auction' of corporate control-is essential because it provides the best available check on the conflict of interest inherent in a board's decision to approve a favored bidder's acquisition proposal."); id. at 275 ("Competing offers and the threat of competing offers provide an effective check on conflicts of interest in negotiated acquisitions.").

21. But see infra Part III.B.2. Ayres' argument is analogous to one economists have long made regarding the performance of an industry in which there is only one firm. Where entry and exit costs are low, the firm will behave not as a monopolist, but as if it were competing with many firms; potential entry is sufficient to protect consumer interests. On the other hand, where there are significant barriers to entry, the firm will charge a monopoly price. In this way, the ex post approach to lockups is not unlike the economic notion of "contestability" or "potential competition," according to which the efficiency of an industry's performance is thought to depend less on the number of actual competitors and more on the size of the barriers to entry and exit facing potential competitors. See JEAN TIROLE, THE THEORY OF 
an ex post vantage point, therefore, there are basically two types of lockups: A nonforeclosing lockup has no effect on who wins an auction, whereas a foreclosing lockup may preclude higher valuing bidders. According to this approach, courts should invalidate only foreclosing lockups. We will discuss and criticize the ex post approach in Section $C$ of this Part.

Courts and scholars regard three categories of arrangements as lockups: (1) cash payments by the target company to the recipient bidder ("breakup fees" or "termination fees");" (2) options held by the recipient bidder to acquire a certain percentage of stock-either treasury shares or authorized but unissued shares-of the target company ("stock lockups"); and (3) options held by the recipient bidder to acquire designated assets or businesses of the target company ("asset lockups"). ${ }^{23}$ The volume of a lockup is paid to the recipient bidder only if the merger agreement is terminated (because, for instance, a higher bidder acquires the company). ${ }^{24}$ Because lockups of all types guarantee

INDUSTRIAL ORGANIZATION 307-14 (1988); DOUGLAS F. GREER, INDUSTRIAL ORGANIZATION AND PUBLIC POLICY 165-66 (1980) (describing doctrine of "potential competition"); RICHARD A. POSNER, ANTITRUST LAW: AN ECONOMIC PERSPECTIVE 121-25 (1976). The logic underlying the ex post approach is also similar to arguments sometimes made on behalf of an "auctioneering rule" in the takeover context. See, e.g., Bebchuk, supra note 9, at 25 n.8.

22. Breakup fees are analytically similar to stock and asset lockups. And although our theoretical treatment of lockups in Part III, infra, applies to all types of lockups, breakup fees falling in the range between 1 and $21 / 2 \%$ of the aggregate purchase price are often not treated as lockups by either courts or litigants. Courts often uphold breakup fees. See, e.g., QVC Network, Inc. v. Paramount Communications, Inc., 635 A.2d 1245, 1271 (Del. Ch. 1993) (less than 1.2\%); In re Vitalink Communications Corp. Shareholders Litig. Civ. A. No. 12085, 1991 WL 238816, at *7 (Del. Ch. Nov. 8, 1991) (1.9\%); Roberts v. General Instruments Corp., Civ. A. No. 11639, 1990 WL 118356, at *6 (Del. Ch. Aug. 13, 1990) (2\%); Braunschweiger v. American Home Shield Corp., Civ. A. No. 10755, 1989 WL 128571, at *6 (Del. Ch. Oct. 26, 1989). And litigants seem not to contest breakup fees as vigorously as they do stock and asset lockups. Indeed, in the recent battle over Paramount, the Delaware Chancery Court enjoined the stock lockup but not the breakup fee that Paramount granted to Viacom. For a more general description of the battle over Paramount, see infra Part II.B.1.b. Viacom challenged the injunction on appeal, but, for unstated reasons, QVC did not challenge the lower court's enforcement of the $\$ 100$ million breakup fee. Paramount Communications, Inc. v. QVC Network, Inc., 1994 WL 30181, at $* 21$, n.22 (Del. Feb. 4, 1994). The Delaware Supreme Court, sua sponte, indicated that the Chancery Court should have granted the preliminary injunction against the breakup fee. See id. In Revlon, both the Chancery Court and the Supreme Court of Delaware preliminarily enjoined the payment of a $\$ 25$ million breakup fee to Forstmann. For a more general discussion of the takeover battle over Revlon, see infra Part II.B.l.a. Forstmann subsequently did not pursue a trial on permanent injunction. One somewhat cynical explanation for nonrecipient bidders' greater willingness to absorb the costs of breakup fees has to do with the perception of breakup fees as a kind of contingency-fee arrangement for compensating the recipient bidder's lawyers and other agents in the event the target is sold to a nonrecipient bidder. It is possible that the advisors and agents of nonrecipient bidders see this sort of contingency-fee arrangement as being in their own long-term interests, and advise accordingly. In any event, our analysis of Delaware courts' treatment of lockups is limited only to cases involving stock or asset lockups.

23. See Cramton \& Schwartz, supra note 2, at 37; Stephen Fraidin \& Joseph Franco, Lock-Up Arrangements, 14 REV. SEC. REG. 821 (1981).

24. The value of a stock lockup, for instance, arises from the difference between the option exercise price, multiplied by the number of shares subject to the option, and the price paid by the successful bidder. In general, the number of shares subject to a lockup option is not greater than $19.9 \%$ of the outstanding shares of the target. This is because the rules of both the New York and American Stock Exchanges require shareholder approval of the issuance of a greater percentage of shares. The process of obtaining shareholder approval would typically create enough delay for an open auction to develop. On one hand, were the recipient outbid in such an auction, shareholders would not approve the lockup. On the other hand, were the recipient not outbid, the lockup, even if approved by shareholders, would retain little or no value. See 
the recipient bidder some of the target's assets if a nonrecipient bidder wins the auction, lockups are thought to lower the value of the target to nonrecipient bidders, and, thus to give the recipient bidder an advantage in the auction.

\section{B. The Ex Ante Approach}

\section{Delaware's Purported Ex Ante Standard}

When reviewing most board decisions, Delaware courts apply the highly deferential business judgment rule. ${ }^{25}$ When reviewing a board decision to grant a lockup, however, they apply more "exacting scrutiny."26 In 1985, Delaware courts first announced the "proportionality standard,"

infra Part III.C.2 (describing several potential purposes of lockups, none of which would be served after an open auction). Consequently, target boards rarely if ever option more than $19.9 \%$ of the target's stock in stock lockups. Asset lockups involve compensation to the extent that the exercise price is below the fair value of the assets subject to the option.

Ian Ayres emphasizes that "[t]he term 'lock-up' only is appropriate for the more extreme treasury sales which foreclose competitive bids, because only these agreements truly discourage higher valuing bidders from raising the initial bidder's ante." Ayres, supra note 9, at 707. And, as we argue in this Article, the term "lockup" is a misnomer for all lockups. Consistent with common usage, however, we shall refer to all arrangements described above as lockups.

25. See infra note 48 (describing business judgment rule). For simplicity, this Article focuses only on Delaware law. Nearly half of the corporations listed on the New York Stock Exchange and more than half of the Fortune 500 companies are domiciled in Delaware. Laurie Hays, Delaware Effort To Draft Takeover Law Stirs a Debate, Disturbs SEC Members, WALL ST. J., Dec. 14, 1987, at 11.

26. Mills Acquisition Co. v. Macmillan, Inc., 559 A.2d 1261, 1284 (Del. 1988); see also QVC Network Inc. v. Paramount Communications, Inc., 635 A.2d 1245, 1268 n.44 (Del. Ch. 1993) ("enhanced security").

27. See Unocal Corp. v. Mesa Petroleum Co., 493 A.2d 946, 955 (Del. 1985) ("[A] defensive measure ... must be reasonable in relation to the threat posed.").

In evaluating challenges to lockup options, courts initially considered the extent to which both federal law and state common law restrict the ability of the boards of directors of target corporations to grant lockup options to favored bidders. For example, in Mobil Corp. v. Marathon Oil Co., 669 F.2d 366 (6th Cir. 1981), cert. denied, 455 U.S. 982 (1982), the hostile bidder, Mobil Corporation, challenged both the stock and the asset lockups granted by the board of directors of the target corporation, Marathon Oil Company, to the white knight, U.S.S. Corporation, on the grounds that the lockup options violated Section 14(e) of the Williams Act. In reversing the decision of the District Court, which had denied the motion to enjoin exercise of the options, the Circuit Court held that "there appears to be a substantial likelihood that Mobil [Corporation] will succeed on its claim that execution of . . the . . . options are "manipulative acts or practices, in connection with [a] tender offer' in violation of section 14(e), 15 U.S.C. $\$ 78$ (e)." Id. at 369. This decision, which indicated that Section 14(e) of the Williams Act would permit federal regulation of lockup options, was widely criticized before being overruled by the Supreme Court in Schreiber v. Burlington N., Inc., 472 U.S. 1 (1985), in which the Court held that 'the term 'manipulative' as used in $\S 14(\mathrm{e})$ requires misrepresentation or nondisclosure," id. at 12 . As a result, the most recent judicial evaluations of the validity of lockups have focused exclusively upon state law standards. See, e.g., Data Probe Acquisition Corp. v. Datatab, Inc., 722 F.2d 1, 4 (2d Cir. 1983), cert. denied, 465 U.S. 1052 (1984) (criticizing federal regulation of lockups under section 14(e)); Buffalo Forge Co. v. Ogden Corp., 717 F.2d 757, 760 (2d Cir.), cert. denied, 464 U.S. 1018 (1983) (same); Schreiber v. Burlington N., Inc., 731 F.2d 163, 165 (3d Cir. 1984), aff'd, 472 U.S. 1 (1985) (same); Feldbaum v. Avon Products, Inc., 741 F.2d 234, 237 (8th Cir. 1984) (same); Dixon v. Ladish Co., 597 F. Supp. 20, 32-33 (E.D. Wis. 1984) (same); Swanson v. Wabash, Inc., 577 F. Supp. 1308, 1316 (N.D. Ill. 1983) (same); Marshall Field \& Co. v. Icahn, 537 F. Supp. 413, 422 (S.D.N.Y. 1982) (same).

This Article focuses exclusively on the common law of the state of Delaware and does not discuss the validity of lockup agreements under the federal securities laws. 
have more recently summarized as follows: "It is not necessarily inconsistent ... for directors to grant lockup options (for stock or assets) . . . . But, 'the board's action must be reasonable in relation to the advantage sought to be achieved.",28 "In particular, [the board has] the obligation of acting reasonably to seek the transaction offering the best value reasonably available to the stockholders." ${ }^{29}$ Thus, Delaware courts scrutinize lockups primarily from an ex ante vantage point, focusing on whether the target board sacrificed to the recipient bidder more than was reasonable in relation to what the target shareholders gained in return-that is, on whether the lockup was supracompensatory. In one well-known case, for instance, the court invalidated a lockup, reasoning that the bid received in return for the lockup did not "materially enhance[] general stockholder interests."30

But the proportionality standard, as applied to lockups, is virtually without content. The Supreme Court of Delaware threatens that "[i]f the grant of an

28. Rand v. Western Airlines, Inc., [1989-1990 Transfer Binder] Fed. Sec. L. Rep. (CCH) II 94,751, at 94,053 (Del. Ch. Sept. 11, 1989) (emphasis added) (quoting Mills Acquisition Co. v. Macmillan, Inc., 559 A.2d 1261, 1288 (Del. 1988)); see also id. ("[i]f the grant of an auction-ending provision is appropriate, it must confer a substantial benefit upon the stockholders in order to withstand exacting scrutiny by the courts.' ... Only after satisfying this standard will the directors' actions be accorded the protection of the business judgment rule." (quoting Macmillan, 559 A.2d at 1284)); In re Holly Farms Shareholders Litig., 1988 Fed. Sec. L. Rep. (CCH) II 94,181 (Del. Ch. Dec. 30, 1988) ("The presumptions of the business judgement rule will generally not protect acts of directors who grant a lock up in an active bidding situation where there is more than one bona fide bidder."); Revlon, Inc. v. MacAndrews \& Forbes Holdings, Inc., 506 A.2d 173, 176 (Del. 1986) ("lock-ups and related agreements are permitted under Delaware law where their adoption is untainted by director interest or other breaches of fiduciary duty."); Roberts v. General Instrument Corp., 1990 Fed. Sec. L. Rep. (CCH) I 95,465 (Del. Ch. Aug. 13, 1990) ("even a disinterested board must meet an enhanced test. ... requir[ing] a judicial determination of reasonableness in the circumstances").

29. Paramount Communications, Inc. v. QVC Network, Inc., 1994 WL 30181, at *8 (Del. Feb. 4, 1994); see also id. at $\neq 9$ ("In the sale of control context, the directors must focus on one primary objective-to secure the transaction offering the best value reasonably available for the stockholders .....").

To put a little more flesh on that standard, the Delaware Supreme Court has explained that

[t]he key features of an enhanced scrutiny test are: (a) a judicial determination regarding the adequacy of the decisionmaking process employed by the directors, including the information on which the directors based their decision; and (b) a judicial examination of the reasonableness of the directors' action in light of the circumstances then existing. The directors have the burden of proving that they were adequately informed and acted reasonably.

Id. at $* 11$. This Article focuses on only the second feature. With respect to that feature, although courts are expected to review the "substantive merits of a board's actions," the board's decision will be upheld so long as it was "within a range of reasonableness." Id.

30. MacMillan, 559 A.2d at 1286; see also In re Holly Farms Corp. Shareholders Litig., 1988 Fed. Sec. L. Rep. (CCH) I 94,181, at 91,641, 91,644-45 (Del. Ch. Dec. 30, 1988) (enjoining lockup that was not necessary to obtain bidder's proposal).

In applying their reasonableness standard, Delaware courts sometimes claim to give some weight to a lockup's ex post effects. For example, the Revlon court struck down a lockup in part because the lockup had a "destructive effect on the auction process." Revlon, Inc. v. MacAndrews \& Forbes Holdings, Inc., 506 A.2d 173, 183 (Del. 1986). Similarly, Chancellor Allen has upheld a lockup in part on the grounds that it did not "imped[e] the emergence of an alternative proposal." Braunschweiger v. American Home Shield Corp., Fed. Sec. L. Rep. (CCH) II 94,779, at 94,187, 94,193 (Del. Ch. Oct. 26, 1989). However, courts have offered no useful means of measuring a lockup's ex post effects. See infra text accompanying notes 34-39. Moreover, where courts consider a lockup's ex post effects, they do so from an ex ante perspective; that is, they ask whether target shareholders were adequately compensated for any foreclosure that may have occurred. See, e.g., infra note 31 and accompanying text; Braunschweiger v. American Home Shield Corp., Fed. Sec. L. Rep. (CCH) II 94,779, at 94,187 (Del. Ch. Oct. 26, 1989). 
auction-ending provision ... [is to be upheld], it must confer a substantial benefit upon the stockholders,"31 but it nowhere explains exactly how to identify lockups that are "auction-ending" or benefits that are "substantial." And, as will become evident, the few vague criteria that Delaware courts have articulated seem both ill-defined and arbitrarily applied.

Most often, courts ask whether a lockup enticed a bidder to enter the auction contest. ${ }^{32}$ For instance, a lockup might do so by extending the time within which potential nonrecipient bidders can make a bid or by attracting the recipient bidder's participation. ${ }^{33}$ A significant problem with the enticement criterion, however, is that courts are not equipped to distinguish auctionfostering lockups from auction-ending lockups. ${ }^{34}$ The distinction, if there is one, can be extremely subtle, for even a lockup intended to foster an auction will have an auction-ending effect. ${ }^{35}$ As one court conceded, "[a]ll auctions must end sometime, and lockups by definition must discourage other bidders." 36 Another court explained that "even when designed to promote another bid, a good (i.e., effective) lockup may well end the bidding after that one last bid it induces is on the table."37 Scholars, too, have criticized the distinction as unworkable. ${ }^{38}$ As Stephen Bainbridge laments: "Unfortunately, whether a particular lock-up is likely to elicit or preclude new bids . . . is something that can be known with certainty only after the fact." ${ }^{39}$

31. Macmillan, 559 A.2d at 1284.

32. See, e.g., Revlon, 501 A.2d at 1250 ("A lock-up provision ... must advance or stimulate the bidding process, not retard it ... ."); Revlon, 506 A.2d at 183 ("Such options can entice other bidders to enter a contest for control of the corporation, creating an auction for the company and maximizing shareholder profit.... [Even though] those lock-ups which draw bidders into the battle benefit shareholders, similar measures which end an active auction and foreclose further bidding operate to the shareholders" detriment."); Macmillan, 559 A.2d at 1284 ("If the grant of an auction-ending provision is appropriate, it must confer a substantial benefit upon the stockholders in order to withstand exacting scrutiny by the courts."); In re Holly Farms Shareholders Litig., 1988 Fed. Sec. L. Rep. (CCH) II 94,181, at 91,641, 91,644-45 (Del. Ch. Dec. 30, 1988) ("[T]he lock up was [not] necessary to obtain ConAgra's proposal"); Hecco Ventures v. Sea-Land Corp., 1986 WL 5840, at *4 (Del. Ch. May 19, 1986) (enforcing lockup that did not act to halt an active auction); Samjens Partners I v. Burlington Indus., Inc., 663 F. Supp. 614, 624 (S.D.N.Y. 1987) ("In coordinating the bidding process, the board can institute strategies, such as granting a 'lock-up' agreement, . . . but only if their strategies enhance the bidding."); see also Hanson Trust PLC v. ML SCM Acquisition Inc., 781 F. 2d 264, $281-83$ (2d Cir. 1986) (enjoining lockup that was considered to be foreclosing); Black \& Decker Corp. v. American Standard, Inc., 682 F. Supp. 772, 784, 787-88 (D. Del. 1988) (finding lockup impermissible if it forecloses further bidding to shareholders" detriment).

33. See infra Part III.C.1 (describing and raising doubts regarding the conventional justifications for lockups).

34. We argue below that because they cannot apply this standard competently, courts have been forced to adopt a de facto rule that eliminates any potentially beneficial effect of lockups. See infra Part II.B.2.

35. See Ayres, supra note 9, at 706 (describing that trade-off).

36. Cottle v. Storer Communication, Inc., 849 F.2d 570, 576 (11th Cir. 1988).

37. Freedman v. Restaurant Assoc. Indus., Inc., 1987 Fed. Sec. L. Rep. (CCH) II 93,502, at 97,214, 97,219 n.3 (Del. Ch. Oct. 16, 1987).

38. See, e.g., Bainbridge, supra note 1, at 299-300; Herzel et al., supra note 17, at 177; Johnson \& Siegel, supra note 1 , at $374-75$.

39. Bainbridge, supra note 1, at 323; see also Note, Lock-Up Options, supra note 17, at 1079 ("No simple test or formula can be laid down to assist in the difficult task of deciding whether a given lock-up is designed to stimulate bidding or to prolong unduly the directors' tenure."). 
In any event, courts usually enforce even a lockup that they believe is auction-ending if the lockup was given in exchange for a bid increase; the more substantial the bid increase is, the more willing courts claim to be to uphold the lockup. ${ }^{40}$ But this criterion for enforcement is also flawed. First, courts cannot determine whether a given bid increase justifies a given lockup, because the size of a lockup and the size of the bid increase depend on variables that a court cannot observe or measure, such as the board's and bidder's perceived threat of competing bids. ${ }^{41}$ Because any bidder's goal is to win the target with as low a bid as possible, a bidder will not raise its bid except in response to a competing bid or in exchange for a lockup that reduces the risk of a competing bid. In any event, parties can satisfy this bid-increase criterion by engaging in sham negotiations in which a bidder offers a disloyal board an artificially low initial bid only to increase it in exchange for a supracompensatory lockup. ${ }^{42}$ For those reasons, courts appear to have been wrongly influenced by the presence and size of bid increases.

Occasionally, and quite arbitrarily, courts take into account other considerations when deciding whether to enforce or enjoin a lockup. For example, in In re KDI Corp. Shareholders Litigation, ${ }^{43}$ the court upheld a lockup that neither increased the pool of bidders nor led to an increase in the bid price. In that case, it was enough that the lockup led to better non-price "terms" in the merger agreement than the bidder had initially proposed. As with the other criteria, it is hard to know the extent to which the terms of a deal must be improved to justify a lockup. Additionally, the problem of sham negotiations seems likely to be greater than ever when courts enforce lockups simply because they appear to have been granted in exchange for an improvement in the bidder's terms.

In Yanow v. Scientific Leasing Inc., ${ }^{44}$ the court upheld a lockup even when it clearly narrowed the pool of auction participants. The court based its decision on the argument that in service businesses, such as the target's, "key

40. In some cases, courts enforce lockups because of substantial bid increases. See, e.g., Braunschweiger v. American Home Shield Corp., Fed. Sec. L. Rep. (CCH) II 94,779 (Del. Ch. Oct. 26, 1989), Cottle, 849 F.2d at 576 ("In exchange for the asset lock-up, Storer ultimately received a cash price of $\$ 91$ per share, $\$ 16$ more per share than KKR's previous offer . . . ."). In other cases courts enjoined lockups because the resultant bid increases were insubstantial. See, e.g., Mills Acquisition Co. v. Macmillan, Inc., 559 A.2d 1261, 1286 (Del. 1988) ("Macmillan cannot seriously contend that they received a final bid from KKR that materially enhanced general stockholder interests. . . . When one compares what $\mathrm{KKR}$ received for the lockup, in contrast to its inconsiderable offer, the invalidity of the agreement becomes patent."); Revlon, Inc. v. MacAndrews \& Forbes Holdings, Inc., 506 A.2d 173, 184 (Del. 1986) ("[T] he Revlon board ended the auction in return for very little actual improvement in the final bid."); see also Hanson Trust PLC v. ML SCM Acquisition Inc., 781 F.2d 264, 281-82 (2d Cir. 1986) (invalidating lockup in part because bid increase was minimal).

41. See infra Part III.C.2-3 (describing in detail numerous ex ante justifications for lockups).

42. See Ayres, supra note 9 , at 700 n.49.

43. No. 10,278, 1988 Del. Ch. LEXIS 143 (Del. Ch. Nov. 1, 1988); see also In re Frederick Rand v. Western Airlines Inc., No. 8632, 1994 Del. Ch. LEXIS 26 (Del. Ch. Feb. 25, 1994).

44. Nos. 9536, 9561, 1991 WL 165304 (Del. Ch. 1991). The Yanow court believed that the lockup was not foreclosing. Id. at $* 6$ n.6. 
employees ... could be 'raided' by, or might defect to," the target's competitors in the event that the target's "availability for sale were publicly disclosed." ${ }^{45}$ It is not at all clear, however, why the court chose this case to show such deference to the board's business judgment. Delaware courts have not mentioned this consideration in cases before or since the Yanow decision. Moreover, the holding itself rests upon an unproven proposition-that raiding and defecting are more likely to occur in a business sold through an auction than one sold without an auction. In fact, they might well be simply a consequence of the firm being sold, unrelated to the method by which the sale takes place. On the other hand, it is conceivable that the court's deference would, under certain circumstances, be appropriate. So, for example, a court might ask: Did the board evaluate whether there were potential bidders for the business whom key employees would likely have viewed as undesirable employers? And were those key employees irreplaceable? Both questions might have been answered in the affirmative, in which case deference might be appropriate; if they were not, or if, as in Yanow, they were not considered by the board, then judicial deference seems inappropriate.

Finally, courts sometimes inquire into the adequacy of the option exercise price relative to the value of the stock or assets optioned. ${ }^{46}$ There are problems with that criterion too. First, as one court has recognized, a loyal board may grant a lockup containing a bargain exercise price as a means of encouraging the recipient to make or raise its bid. ${ }^{47}$ Thus, no inference should be drawn regarding the loyalty of a lockup from the lockup's exercise price. In any case, the exercise price of an option does not, by itself, indicate the option's value. Indeed, a stock lockup with an exercise price exceeding the stock's pre-bid market price or even the recipient bidder's bid, can be quite substantial depending on, among other things, the size of the option (e.g., the number of shares optioned).

More generally, whatever the purported criteria may be, the proportionality standard seems fundamentally flawed inasmuch as courts seem no better equipped to assess whether a lockup enhanced shareholder welfare at the time it was granted than they are to assess non-takeover-related business decisions. Yet courts have greatly insulated the latter from judicial scrutiny under the business judgment rule, largely because of their conceded inability to make such assessments. ${ }^{48}$ As Judge Kearse of the Second Circuit argues, questions

45. Id. at *9.

46. See, e.g., Revlon, 506 A.2d at 178 (option price said to be between $\$ 100$ million and $\$ 175$ million below assessed value); Hanson Trust, 781 F.2d 264, 275-76, 278-80 (drawing attention to board's failure to consider evidence "that the optioned assets were worth considerably more than their option prices"); Buffalo Forge Co. v. Ogden Corp., 717 F.2d 757, 759 (2d Cir. 1983) (enforcing lockup because price was not inadequate from business judgment standpoint).

47. Hanson Trust, 781 F.2d at 276.

48. Cf. Ronald J. Gilson \& Reinier Kraakman, Delaware's Intermediate Standard for Defensive Tactics: Is There Substance to Proportionality Review?, 44 Bus. LAW. 247 (1989) ("Because evaluating 
regarding the loyalty of a lockup "are precisely the types of issues that courts are ill-equipped to explore and whose judicial exploration the business judgement rule is designed to preclude." ${ }^{49}$ If we are to take this reasoning seriously, it seems courts should be at least as deferential in their review of lockups as they are in reviewing other complex business decisions. ${ }^{50}$

a sale of the company is a complex business decision, management's response to a takeover bid resembles the normal business decisions that the business judgment rule largely insulates from judicial review."). The business judgment rule-the standard of judicial review applied to most ordinary business transactions--is "a presumption that in making a business decision the directors of a corporation acted on an informed basis, in good faith and in the honest belief that the action was taken in the best interests of the company." Aronson v. Lewis, 473 A.2d 805, 812 (Del. 1984); see Pogostin v. Rice, 480 A.2d 619 (Del. 1984); Zapata Corp. v. Maldonado, 430 A.2d 779 (Del. 1981). See generally CLARK, supra note 1, at 141-57. A charge of self-dealing will not be successful if it merely claims that the managers' decision was wrong; it must charge that the decision was corrupt. See id. at 138. If a board action is to be measured by the standard of the business judgment rule, then "unless it is shown by a preponderance of the evidence that the directors' decisions were primarily based on perpetuating themselves in office, or some other breach of fiduciary duty such as fraud, overreaching, lack of good faith, or being uninformed, a [c]ourt will not substitute its judgment for that of the board." Unocal Corp. v. Mesa Petroleum Co., 493 A.2d 946, 958 (Del. 1985). See also Cede \& Co. v. Technicolor, Inc., Nos. 336 \& 337, 1993 Del. LEXIS 398, at *46 (Del. Oct. 22, 1993) (Violation of the business judgment rule arises from "breach[ing] any one of the triads of fiduciary duty-good faith, loyalty or due care.").

The business judgment rule reflects courts' recognition that they are incapable of accurately appraising the value of (much less the motive behind) a board's decisions. See EASTERBROOK \& FISCHEL, supra note 5, at 2-3 ("With trivial exceptions all business decisions-including managers' pay, bonuses, stock options, pensions, and perquisites-are taken by or under the supervision of [the] board, with no substantial inquiry by anyone else. Anyone who asks a court to inquire will be brushed off with reference to the business judgment rule."); Gilson, supra note 1, at 823 ("[C]ourts are ill-suited to review the wisdom of complex business judgments."); id. at 822 ("The [business judgment] rule functions less as a standard of management conduct than as a statement of judicial restraint."); see, e.g., Panter v. Marshall Field \& Co., 646 F.2d 271, 299-300 (7th Cir. 1981) (Cudahy, J. concurring in part and dissenting in part); cf. JOHN K. GalbratTH, A TENuRED PROFESSOR 145 (1990) (quoting a fictional Harvard Law Professor: "The law in its admitted majesty cannot possibly distinguish between good financial advice and worthless financial advice."); EASTERBROOK \& FISCHEL, supra note 5, at 98 (explaining that courts are ill-suited for "detecting and rectifying shortcomings in the boardroom"); id. at 98 ("How can courts know whether a poor outcome of a business decision is attributable to poor management (inputs) or to the many other things that affect firms?").

49. Hanson Trust, 781 F.2d at 291 (Kearse, J., dissenting); see also Bainbridge, supra note 1, at 28182.

50. It might be argued that the court's heightened substantive scrutiny of a target board's decisions relating to a takeover bid is premised solely on the especially strong, deleterious effect those decisions could have on the interests of target shareholders. Indeed, the Delaware Supreme Court appears to have justified its heightened review in Paramount II on that basis. Paramount Communications Inc. v. QVC Network, Inc., 1994 WL 30181 (Del. Feb. 4, 1994). Although the court vaguely mentions Paramount management's potential conflict of interest, see id. at *9 (mentioning that in a sale of control transaction, there exists "the possibility, in certain cases, that management may not necessarily be impartial"); id. at *13 ("board action . . . could be contrary to the stockholders"), the court seemed ultimately to base its standard of review on the significance of the transaction to Paramount shareholders. See id. ("There are few events that have a more significant impact on the stockholders than a sale of control .... [Such an] event represents a fundamental (and perhaps irrevocable) change in the nature of the corporate enterprise from a practical standpoint. It is the significance of [such] events that justifies ... focusing on directors' obligation to seek the best value reasonably available to the stockholders . . .."). Perhaps this seeming shift in the justification for heightened scrutiny is partially attributable to an understandable reluctance on the Delaware Supreme Court's part to contradict the Chancery Court's finding that

[t]he independent directors have not demonstrated self-interest in the Viacom transaction, or in perpetuating Mr. Davis or themselves in office. What drives their conduct is a fervently and honestly-held view that the Viacom deal is the only valuable transaction that will serve the best interests of Paramount and its shareholders.

635 A.2d at 1268. 
The flaws in the ex ante approach can be usefully highlighted by an extended analysis of the Delaware Supreme Court's reasoning in Revlon and in Paramount II, the first and most recent cases, respectively, to apply that approach.

\section{a. The Revlon Holding}

In June 1985, Ronald O. Perelman, through Pantry Pride, Inc., began an effort to gain control of Revlon, Inc., Michel C. Bergerac, Revlon's chairman, rejected all of Perelman's initiatives to engage in a friendly acquisition. Pantry Pride then made a series of tender offers, all of which the Revlon board rejected with the aid of a poison pill. In early October, the Revlon board accepted a leveraged buyout proposed by Forstmann Little \& Co. for $\$ 56$ per share. Forstmann later increased its cash offer to $\$ 57.25$ per share in exchange for receiving a lockup option to buy shares in two divisions of Revlon. Pantry Pride then responded with a bid of $\$ 58$ per share, contingent upon the lockups' invalidation by Delaware courts. The Revlon court enjoined the lockup, emphasizing several sources of concern, including the fact that the lockup was granted (1) in exchange for an increase of only $\$ 1.00$ in the premium to Revlon shareholders and (2) despite Pantry Pride's statement in prior discussions that it would top any Forstmann bid increase.

Contrary to the court's conclusions, however, those two features may actually justify the lockup. For instance, the court ignored the fact that the lockup was granted after several rounds of bidding had already taken place, at a time when a $\$ 1.00$ bid increase was substantial. Pantry Pride initially proposed to Revlon's board an acquisition for between $\$ 42$ and $\$ 45$ per share. When Revlon rejected that proposal, Pantry Pride responded by making a tender offer at $\$ 47.50$ per share. Revlon then entered into a leveraged buyout agreement with Forstmann for $\$ 56$ per share. In response, Pantry Pride raised its bid to $\$ 56.25$ (an increase of only 25 cents) and announced that it would counter any subsequent Forstmann bid with a slightly (i.e., 5 cents per share) higher bid. At that point, Revlon agreed to grant a lockup in exchange for Forstmann's bid of $\$ 57.25$ per share. Thus, Forstmann's final bid was more

Whatever the explanation for the Supreme Court's shift in emphasis, this alternative justification for heightened scrutiny seems flawed in at least two ways. First, if courts are ill-equipped to assess the desirability of a board's decisions, then the heightened significance of a particular board decision arguably suggests that courts should be especially deferential to that board decision. Second, Delaware courts have not applied the same heightened substantive scrutiny in other contexts in which a board's decision may well be as threatening, if not more threatening, to shareholders' interests than is a board's decision to grant a lockup. For instance, Delaware courts have been quite deferential to the boards of acquiring firms and to target boards that reject all takeover offers. Cf. infra text accompanying notes 363-71 (arguing that shareholders stand to lose more from a target board's decision to resist all bidders than they do from a target board's decision to resist all but one bidder). See generally Bernard S. Black, Bidder Overpayment in Takeovers, 41 STAN. L. REV. 597 (1989) (advancing hypothesis that a portion of the takeover premiums enjoyed by target shareholders are attributable to fact that bidders pay too much for targets). 
than $\$ 10$ above Pantry Pride's original bid, and almost $\$ 18$ above Revlon's pre-bid market price. Moreover, the $\$ 1$ bid increase was four times as large as Pantry Pride's previous bid increase and twenty times as large as Pantry Pride's promised counter. Taken in context, Forstmann's bid increase seems quite substantial-that is, large enough to satisfy Delaware's bid-increase criterion.

Pantry Pride's promise to match and nominally exceed any Forstmann offer may have further justified the lockup. If it could not obtain an enforceable lockup and believed Pantry Pride's threat credible, Forstmann would have rationally concluded that it was destined to lose any open-bidding contest. Rather than serve as a mere "stalking horse," Forstmann would have chosen to give up the contest altogether. Bidding would have ceased at Pantry Pride's previous bid, costing Revlon shareholders the Forstmann increase from $\$ 56.25$ to $\$ 57.25 .^{51}$ Additionally, had Forstmann chosen to withdraw, Pantry Pride could have reduced its bid and acquired Revlon at an even lower price: Unlike Forstmann, which had entered into a binding agreement to acquire Revlon at a particular price, Pantry Pride was under no obligation to keep its bid open. Thus, by granting the lockup, the Revlon board netted its shareholders a premium of at least $\$ 1.00$ per share and possibly more.

It is also worth noting that the terms of the Forstmann offer were significantly more favorable to Revlon than those of the previous Pantry Pride offers, in that the latter contained a financing condition. A financing condition permits a bidder to walk away from a deal if the bidder is unable to obtain financing and, therefore, reduces the value of the offer to target shareholders

51. Because "ratcheting" bids of the sort employed by Pantry Pride often serve to deter higher bids, company-led auctions typically prohibit them. Cramton \& Schwartz, supra note 2, at 38; Stephen Fraidin \& Janice MacAvoy, Rule of Business Judgment and Directors' Flexibility, N.Y. L.J., Mar. 21, 1988, at 22. 


\section{significantly. ${ }^{52}$ Why the Delaware court ignored the offers' terms in Revlon is never made clear. ${ }^{53}$}

52. When a bidder offers to acquire a target company for cash, the bidder must either (a) have sufficient cash resources to fund the purchase price and related expenses, (b) have binding contractual arrangements with sources of funding for an amount equal to the purchase price and related expenses, or (c) condition its offer and any merger agreement on the bidder obtaining the necessary financing ("financing conditions"). Bidders typically choose the third alternative. It is often the case that bidders do not have sufficient available cash resources, particularly in leveraged buyout transactions. The altemative of entering into binding contractual arrangements simultaneous with the acquisition is viewed as undesirable for several reasons. First, financial institutions typically charge potential borrowers a commitment fee when a loan commitment is made. Those fees, which are generally a percentage of the amount to be loaned and can be very large sums, are required to be paid when the loan commitment is made and are nonrefundable. Accordingly, bidders are reluctant to incur a potentially large sunk cost, given the fact that a successful bid may be uncertain in the typical auction setting. Second, bidders are sometimes concerned that disclosure of a potential bid to sources of financing can result in leaks. Leaks could interest other bidders in the proposed target at a time deemed undesirable, could tip others to pricing flexibility and constraints, and could result in an increase in the target company's market price, thus narrowing the apparent "premium" to be offered. Finally, if a bidder is contractually bound to make a particular acquisition at a specific price, the sources of financing will have a significant degree of bargaining power in negotiating the cost and terms of the financing.

Financing conditions as set forth in tender offers and merger agreements vary widely in their language, but regardless of how such conditions are drafted, they permit bidders to abandon transactions without liability, even after a merger agreement is signed. Financing for an acquisition transaction should be available as long as the amount to be borrowed is less than the value of the assets to be acquired. However, financing conditions permit the potential buyer to evaluate the price (interest rate, fees, and possible equity component) and terms (such as covenants regulating the operations of the business to be acquired and the amortization schedule) of the financing. Given the number of factors a bidder would be legitimately entitled to consider in evaluating proposed financing for an acquisition, the bidder is reasonably free to reject a proposed financing arrangement. If the bidder rejects a financing arrangement, it can then either abandon the transaction, or, particularly if it has learned of the amount and structure of the unsuccessful competing bids, renegotiate the terms of the transaction with the target at a lower value for the target shareholders, thereby making the financing easier to obtain and less expensive and restrictive. In fact, if a bidder has the benefit of a financing condition, it has virtually been granted an option to acquire the target company at a designated price-the equivalent of a call option. If a bidder were to avail itself of the option element of a financing condition, it might suffer some reputational damage: future target companies might not agree to be acquired by it subject to such a condition. Although the risk of reputational damage may be of concern to bidders, there is very little support in the case law for a board of directors of a Delaware corporation to reject the highest bid because of reputational factors relating to the bidder. But see, e.g., Mills Acquisition Co. v. MacMillan, Inc., 559 A.2d 1261, 1282 n.29 (Del. 1989). Indeed, the Delaware Supreme Court in the Revlon case specifically equated the terms of Forstmann's merger agreement, which was not conditioned on financing, with Pantry Pride's offer, which contained a financing condition, and which, in any event, could have been withdrawn or reduced.

53. The Delaware court emphasized that the Revlon board was wrongly motivated in its choice among bidders by its fear of liability to certain noteholders. Revlon, Inc. v. MacAndrews \& Forbes Holding, 506 A.2d 173, 179, 184 (Del. 1986). In response to Pantry Pride's initial hostile tender offer, Revlon made an exchange offer to purchase up to $\$ 10$ million of its outstanding shares in return for a package of notes and preferred stock. The notes contained several anti-takeover covenants limiting Revlon's ability to incur additional debt unless Revlon's outside directors waived the covenants. Because Forstmann's offer would have required that Revlon incur substantial additional debt, Revlon's board waived the restrictive covenants in the notes, causing the market price of the notes to decrease rapidly. As part of its final offer, Forstmann agreed to exchange new senior notes for the earlier issued notes in order to raise their market price and thereby satisfy the complaints of some noteholders and, in turn, the concerns of the Revlon board. The Delaware court held that the Revlon board was wrongly influenced by its concern for liability to those noteholders in choosing between bidders.

The court's conclusion seems erroneous. There was no reason for the directors to fear liability to the noteholders. In Delaware and elsewhere, a consistent line of case law and commentary has rejected the notion that any fiduciary duty runs from directors to noteholders, except under circumstances not relevant to Revlon. See generally Stephen Fraidin \& Faith Stevelman, Duties to Bondholders in Recapitalizations and Restructurings, at 277 (PLI Corp. Law \& Practice Course Handbook Series No. 754, 1991); 


\section{b. The Paramount II Holding}

Paramount Communications Inc. has long been openly devoted to acquiring entertainment and publishing companies. Indeed, it was that goal that motivated Paramount's famous but failed attempt to acquire Time Inc. in 1989..$^{4}$ After losing the contest for Time Inc., Paramount began merger negotiations with Viacom Inc. in 1990. Negotiations that year ended when neither chairman of the two companies would agree to the demands of the other: Martin Davis of Paramount insisted on becoming the CEO of the new enterprise, and Sumner Redstone of Viacom demanded voting control of the merged entity.

Serious negotiations began again in April 1993, and by July the two sides had reached agreement in principle on certain key points (including that Davis would become CEO and Redstone would have voting control of the merged

Corporate Debt Financing Project, American Bar foundation, Commentaries on Indentures (1971). In the leading pre-Revlon decision on the issue, the Delaware Chancery Court held that "[i]t seems likely that corporate restructurings designed to maximize shareholder values may in some instances have the effect of requiring bondholders to bear greater risk of loss and thus in effect transfer economic value from bondholders to stockholders." Katz v. Oak Indus. Inc., 508 A.2d 873, 879 (Del. Ch. 1986). Even when the Delaware courts have acknowledged certain exceptions like fraud or insolvency, they have generally been loath to employ them. See, e.g., Harff v. Kerkorian, 324 A.2d 215, 22I-22 (Del. Ch. 1974), aff'd in part and rev'd in part on other grounds, 347 A.2d 133 (Del. 1975). Thus, the Revlon board faced virtually no risk of liability to noteholders.

It is not surprising, then, that the court offered no legal citation to support its assertion that directors were facing a real threat of liability; it offered only a citation to a Wall Street Journal article in which noteholders were said to be considering litigation. Revlon, 506 A.2d at 178. Indeed, even the court seems to have suggested that there was no threat of director liability to noteholders when it wrote that "the rights of the noteholders were fixed by agreement, and there is nothing of substance to suggest that any of those terms were violated." Revlon, 506 A.2d at 182. Moreover, there is little doubt that Revlon could have succeeded in obtaining a similar noteholder protection plan from Pantry Pride had it sought one. In sum, it cannot be plausibly maintained that Forstmann was favored because of Forstmann's willingness to include a noteholder protection plan with its offer. See infra note 179 and accompanying text; cf. CLARK, supra note 1 , at 149 ("[B]ecause of the great complexities typically involved in figuring out the effects of a mixed-motive transaction-whether it was worse for a corporation than some feasible alternative course of action-courts have tended to invent regulatory tests that look more to evidence of unwholesome insider purposes than the substantive fairness or business wisdom of the transaction in question.").

It might be argued that asset lockups, such as the one at issue in Revlon, are especially suspicious, because consideration to the recipient bidder could be offered as easily in some more quantifiable form. The appearance, therefore, is of a target board attempting to give away value that shareholders and courts cannot easily measure. But where the bidder's investment and expected returns are difficult to measure, then the bidder and the target board may be unable to fashion a mutually satisfactory stock lockup or breakup fee. This is likely to be the case, for example, where the bidder is motivated by potential synergistic gains. In such circumstances, an asset lockup may be wholly appropriate. Cf. RICHARD A. POSNER, ECONOMIC ANALYSIS OF LAW 130 (4th ed. 1992) (noting an exception to the general damages rule for cases where "damages are difficult to compute because of a lack of good market substitutes for the performance of the contract breaker"); Alan Schwartz, The Myth that Promisees Prefer Supracompensatory Remedies: An Analysis of Contracting for Damages Measures, 100 YALE L.J. 369, 371 (1990) (making similar argument regarding specific performance); Lewis A. Kornhauser, An Introduction to the Economic Analysis of Contract Remedies, 57 U. CoLo. L. REv. 683, 711-16 (1986) (summarizing arguments in favor of specific performance remedies).

54. See generally Paramount Communications Inc. v. Time, Inc., 571 A.2d 1140, 1143-44 (Del. 1989) ("Paramount I"). The following summary of the events leading up to the Delaware Supreme Court's opinion in Paramount II is based largely on the Chancery Court's description of those events. See QVC Network Inc. v. Paramount Communications Inc., 635 A.2d 1245 (Del. Ch. 1993). 
entity). At that point, Viacom proposed a bid price of approximately $\$ 61$ per share in exchange for, inter alia, the following two termination conditions: first, a $\$ 150$ million breakup fee and, second, a stock option lockup on approximately $20 \%$ of Paramount's outstanding shares exercisable at the market price (then $\$ 55$ per share)..$^{55}$ At $\$ 61$ per share, Viacom's aggregate offer to Paramount was worth more than $\$ 7.5$ billion, and the termination provisions were then worth about $4 \%$ of that amount. Paramount rejected that offer, because it viewed the termination provisions as excessively generous and the bid as inadequate. Negotiations were reinitiated on August 20, 1993, in part out of concern that QVC Network Inc. was interested in making a bid for Paramount. Again, however, those talks led to an impasse over "price and termination provisions." ${ }^{~} 36$ Back-and-forth negotiations continued until, finally, on September 12, the Paramount board approved a proposed merger pursuant to which Viacom would pay $\$ 69$ per share (or a total of $\$ 8.5$ billion) in exchange for the following termination provisions: a $\$ 100$ million breakup fee and a stock option lockup on approximately $20 \%$ of Paramount's outstanding shares exercisable at the bid price of $\$ 69$ per share. ${ }^{57}$ Viacom was to pay with $\$ 750$ million of Viacom class A common stock, $\$ 6.65$ billion of class B common stock, and $\$ 1.1$ billion of cash.

The merger was trumpeted by the principals as offering the "greatest longterm benefits to stockholders and audiences around the world." At a press conference, Sumner Redstone proclaimed that the deal was a "marriage made in heaven ... [that would] never be torn asunder" and stated that only a "nuclear attack" could break up the deal.

Barry Diller, the CEO of QVC, was apparently undeterred by Redstone's admonitions. On September 20, Diller wrote a letter to Davis, proposing an acquisition by QVC of Paramount at a total package price of approximately $\$ 80$ per share. There was no indication at that time that the offer was subject to the lockup being enjoined ${ }^{58}$ Having received only a lukewarm response from the Paramount board, QVC heated things up on October 21. On that day, it filed a motion for a preliminary injunction seeking, among other things, to invalidate the breakup fee and the lockup; and it publicly announced a tender offer for Paramount shares at $\$ 80$ per share (or a total of almost $\$ 10$ billion), conditioned on the non-exercise of the lockup arrangements. QVC was to pay

55. Had Viacom accepted that offer, the stock lockup would have been worth approximately $\$ 150$ million if a competing bidder matched Viacom's offer of $\$ 61$ per share. Thus, in light of both the breakup fee and the lockup, a competing bidder would face a $\$ 300$ million impediment to matching Viacom's per share bid of $\$ 61$. Put differently, the termination provisions had an initial value of $\$ 300$ million.

56. QVC Network Inc. v. Paramount Communications Inc., 635 A.2d 1245, at 1249 (Del. Ch. 1993).

57. The new termination provisions thus had an initial value of $\$ 100$ million. This understates the extent to which these termination provisions were reduced relative to Viacom's previously proposed terms. In the previous offers Viacom had also demanded reimbursement of Viacom's expenses.

58. At that bid, the stock lockup was worth approximately $\$ 250$ million. Thus, in addition to the $\$ 9.5$ billion that QVC offered, QVC was apparently willing to pay an additional $\$ 350$ million $(3.7 \%$ of the total bid) to make good on the termination arrangements with Viacom. 
with $\$ 3.75$ billion cash and the balance in QVC common stock. QVC alleged that the termination agreements were foreclosing other bidders from competing for Paramount and were motivated by Davis's desire to remain at the helm of a major entertainment company. ${ }^{59}$

On October 24, in response to QVC's pressure, Paramount and Viacom amended the merger agreement and the termination features. The Paramount board obtained greater flexibility in negotiating with QVC, and Viacom raised its bid to $\$ 80$ per share. On November 6 , Viacom unilaterally raised its offer price to $\$ 85$ per share. Finally, on November 12, QVC increased its conditional offer to $\$ 90$ per share. ${ }^{60}$

On November 24, the Delaware Chancery Court enjoined the stock lockup but not the breakup fee, ${ }^{61}$ and on December 9, the Delaware Supreme Court affirmed.

Before examining what the Supreme Court did focus on with respect to the lockup, it is illuminating to consider what the court overlooked. Strikingly, the court disregarded the question that has been all but dispositive in many previous cases-that is, "Did the lockup play an important role in encouraging the recipient to make an initial bid or to raise its bid?" In our view, the court would have had greater difficulty reaching its conclusions had it examined the terms of the negotiations between Viacom and Paramount, as Delaware courts have previously done under the proportionality standard.

To begin with, the record contains evidence that Viacom would not have made a bid, but for the lockup in question. ${ }^{62}$ Moreover, recall that the negotiations broke down on three occasions, and twice, the source of the

\footnotetext{
59. QVC's complaint alleged, in pertinent part, as follows:

Viacom and Paramount have conspired to obstruct a fair bidding process, and to seek to defeat or to impair QVC's plainly superior offer, through the use of a "lockup" fee and stock option agreements worth more than $\$ 350$ million-the most unjustified, unreasonable, and burdensome "lockups" in recent financial history. By this lawsuit, QVC seeks to restore a level playing field so that its newly announced $\$ 9.5$ billion tender offer and merger proposal for Paramount-which offers Paramount stockholders a premium of approximately $\$ 2$ billion over Viacom's proposed merger as of the close of the stock market on October 20, 1993-can be considered by Paramount shareholders without the massive financial handicap imposed by the onerous Paramount-Viacom arrangements. Complaint of QVC at I1, QVC Network, Inc. v. Paramount Communications, Inc., 635 A.2d 1245 (Del. Ch. 1993).
}

The purpose and effect of the Lockup Agreements are plain: they were intentionally crafted to block bids other than Viacom's from succeeding. id. at \$4.

[T] he Lockups are a critical component of a plan to assure Paramount's incumbent chief executive of continued tenure at the helm of a major entertainment company. $i d$.

60. If the termination features had both been enforceable and if QVC's bid had not been conditioned on the non-enforcement of those provisions, the breakup fee and stock lockup together would have been worth approximately $\$ 600$ million to Viacom.

61. Viacom appealed the ruling with regard to the lockup, but QVC did not appeal the ruling with regard to the breakup fee. See supra note 22 .

62. According to the depositions of all interested parties, every participant in the negotiation process testified that the lockup agreement was a "deal breaker." See Appellant's Brief at 10, Paramount Communications, Inc. v. QVC Network, Inc., 1994 WL 30181 (Del. Feb. 4, 1994). 
impasse was Paramount's unwillingness to agree to the termination features that Viacom demanded. Viacom's offer on September 12 to reduce the magnitude of the termination provisions and to increase the size of its bid appears to have been a substantial improvement over Viacom's previous offers: The termination features were reduced by $\$ 200$ million, and the bid was increased by $\$ 8$ to $\$ 69$ per share, implying a $\$ 14$ premium over the pre-bid market price. ${ }^{63}$

Thus, the terms of the deal are consistent with the view that Paramount bargained with Viacom in good faith. Indeed, in upholding the $\$ 100$ million breakup fee, the Chancery Court commended the negotiations: The breakup "fee was the product of arms-length bargaining, as evidenced by Viacom reducing its fee demand ... and by Paramount's rejection of Viacom's separate demand for payment of its expenses." ${ }^{\prime 64}$ The Chancery Court seemed not to recognize, much less resolve, the tension that its favorable characterization of the negotiations creates. After all, the negotiations that generated the breakup fee were the same negotiations that produced the stock lockup. ${ }^{65}$

While the Paramount II courts gave short shrift to the possible ex ante benefits of the lockup, they emphasized two general reasons to be suspicious of the lockup. First, the very presence of several "draconian" features seemed to persuade the courts that the Paramount board had failed to seek the best value reasonably available to stockholders. ${ }^{66}$ The courts offered no persuasive arguments, however, to support their conclusory characterizations.

For instance, the courts emphasized certain "unusual" financing features in the lockup that would permit Viacom either to pay for the shares with a senior subordinated note instead of cash, "the Note Feature," or simply to "require Paramount to pay Viacom in cash a sum equal to the difference between the purchase price and the market price of Paramount's stock, "the Put Feature." ${ }^{67}$ Whether or not these financing features are, in fact, "unusual,"

63. Although the roughly $25 \%$ shareholder premium implied by Viacom's bid was only half the size of the average takeover premium in the 1980's, see supra note 142 and accompanying text, the premium was still substantial, especially when viewed in context. For instance, Viacom's premium was offered in 1993, after "[t]he demise of the market for corporate control" which had been robust in the 1980's. Grundfest, supra note 5, at 865 . The dearth of hostile takeovers likely provided Viacom more bargaining leverage than it would have had in the 1980's. Furthermore, Paramount's willingness to pay any premium may have been significantly constrained by Paramount's alleged alternative investment opportunities. Reply Brief of Paramount, Inc. at 3, Paramount Communications, Inc. v. QVC Network, Inc., 1994 WL 30181 (Del. Feb. 4, 1994). In any event, the $25 \%$ premium implied by Viacom's initial bid is an inaccurate measure of what the final premium would be; as will become evident, the lockup did not preclude further escalation of the bid and, hence, the premium.

64. QVC Network Inc. v. Paramount Communications, Inc., 635 A.2d 1245, 1271 (Del. Ch. 1993).

65. See infra text accompanying note 71 (summarizing Chancery Court's rationalization of its differing treatment of the two terms).

66. Paramount Communications, Inc. v. QVC Network, Inc., 1994 WL 30181, at *16 (Del. Feb. 4, 1994); QVC Network Inc. v. Paramount Communications, Inc., 635 A.2d 1245, 1272 (Del. Ch. 1993).

67. Paramount Communications, Inc. v. QVC Network, Inc., 1994 WL 30181, at *4 (Del. Feb. 4 , 1994); QVC Network Inc. v. Paramount Communications, Inc., 635 A.2d 1245, 1268 (noting 
the courts offered no persuasive explanation of what makes them "unreasonable." 68 The Supreme Court did hint, without explanation or support, that the notes paid under the Note Feature might be of "questionable marketability." 69 But the court never considered the potential legitimate benefits of the financing features. ${ }^{70}$ For instance, Viacom may have anticipated being in a cash crunch at the point of exercising the lockup. Furthermore, the provision arguably provides some evidence that the parties took seriously the possibility that a competing bidder would win the contest for Paramount notwithstanding the lockup-or, in other words, that the lockup was not foreclosing.

Consider, next, the Supreme Court's claim that the lockup was suspect because it had no cap: "[The lockup] had the potential to reach (and in this case did reach) unreasonable levels." "The court ignored the fact that virtually all stock lockups, including those that Delaware courts have upheld, share that potential-that is, have no cap. ${ }^{72}$ Put differently, Delaware courts had not previously found a lockup to be unreasonable because of its potential value.

Another feature of the lockup that the Chancery Court found suspicious was that the lockup "pegg[ed] the exercise price to the original deal price (\$69)," which reduced "Viacom's incentive to increase its offer in the face of a higher competing bid. That is because Viacom could profit significantly by

\footnotetext{
"unprecedented" features).

68. Paramount Communications, Inc. v. QVC Network, Inc., 1994 WL 30181, at *15 (Del. Feb. 4, 1994). Although the Note Feature may be uncommon, the Put Feature is not. See, e.g., Stock Option Agreement between National City Corporation and Ohio Bancorp II 7 (April 1, 1993); Stock Option Agreement between The Bank of New York Company, Inc. and National Community Banks, Inc., \$ 7 (Jan. 29, 1993); Stock Option Agreement between HMC Acquisition Corp. II 9 (Jan. 16, 1989); Stock Option Agreement between the Broken Hill Proprietary Company Limited v. Pacific Resources, Inc. II 7 (Jan. 7,
} 1989). 1994).

69. Paramount Communications, Inc. v. QVC Network, Inc., 1994 WL 30181, at *4 (Del. Feb. 4,

70. In our estimation, the financing features could not have had a significant foreclosing effect, and we have encountered no arguments to the contrary. The financial press seems to have made no mention of those features when discussing the terms of the merger agreement and lockup arrangement.

71. Paramount Communications, Inc. v. QVC Network, Inc., 1994 WL 30181, at *4 (Del. Feb. 4, 1994). Although both courts asserted that the lockup grew to unreasonable levels, neither provided any basis for their judgment. It's instructive to consider the Chancery Court's contrasting treatment of the breakup fee, which it upheld, and the lockup. When justifying the breakup fee, the Chancery Court observed that although the $\$ 100$ million breakup fee represented a "quite large absolute dollar amount," it "represent[ed] only $1.2 \%$ of the value of the Original Merger Agreement and a smaller percentage of the present Viacom deal." QVC Network Inc. v. Paramount Communications Inc., 635 A.2d 1245, at 1271 (Del. Ch. 1993). In contrast, when criticizing the stock lockup, the Chancery Court gave the lockup's absolute dollar value as of the date of the opinion, when the lockup had reached its highest value of roughly $\$ 500$ million. The court ignored the relatively insignificant proportionate value of the lockup at that point-roughly 5\%-as well as the fact that the stock lockup was initially worth nothing and, as of the time that QVC filed its suit, worth around only $2.5 \%$ of the total deal. Delaware courts have previously upheld lockups of that proportionate size. See, e.g., Smith v. Pritzker, No. 6342, slip op. (Del. Ch. July 6 , 1982), reprinted in 8 DEL. J. CORP. L. 406, 415 (1983) (approximately 8\%), rev'd on other grounds sub nom. Smith v. Van Gorkom, 488 A.2d 858 (Del. 1985) (en banc).

72. See, e.g., In re Frederick Rand v. Western Air Lines Inc., No 8632, 1994 Del. Ch. LEXIS 26 (Del. Ch. Feb. 25, 1994); Hecco Ventures v. Sea-Land Corp., 1986 WL 5840 (Del. Ch. May 19, 1986). 
allowing a competitive bidder to make the highest bid and then exercis[e] its option." ${ }^{\text {"73 }}$ There is no disputing that this particular lockup had that effect. The problem with the court's reasoning is that every lockup has that effect. ${ }^{74}$ That is, because the holder of a lockup receives the lockup's value if it loses the contest, a recipient bidder can make some profit from losing. ${ }^{75}$ But even assuming arguendo that this lockup provided the recipient an especially strong incentive to adopt that strategy, there are two reasons why the courts should not be troubled by that feature. First, the incentive to lose must not have been too strong in light of the fact that Viacom had never adopted the strategy even after several rounds of bidding and several opportunities to exit gracefully. Second, and more important, if the lockup was designed to give the recipient bidder an incentive to lose the auction contest, there is no basis for the courts' conclusion that the lockup was intended to serve the "improper purpose of 'locking up' the deal for the [recipient bidder] and to deter other potential bidders." 76

In addition to impugning the lockup by describing its features, the Paramount II courts justified invalidating the lockup because of its purportedly foreclosing effect on third-party bidders. The Supreme Court stated that the lockup "made Paramount less attractive to other bidders," and the Chancery Court held that "both the intent and effect of [the lockup] option was to deter competitive bids." 77 The implicit argument seems to be that, whatever the benefits of the lockup to shareholders, those benefits were more than offset by the lockup's chilling effect on other bidders. A problem with such an argument is that all lockups have a chilling effect on other bidders. Again, the courts do not explain what distinguishes this lockup from an acceptable, enforceable lockup. In this case, the lockup was truly nonforeclosing given that QVC made

73. QVC Network Inc. v. Paramount Communications Inc., 635 A.2d 1245, at 1272 (Del. Ch. 1993). The same point was emphasized in QVC's Complaint:

The unreasonableness of the Lockup Agreements is further demonstrated by their structure. ... . [T] he Lockups plainly create a massive disincentive for Viacom to make a higher bid. In fact, according to the Wall Street Journal, Viacom's financial advisors have "put out the word that [Viacom] wouldn't necessarily enter a costly bidding war, but might just sit back and collect the proceeds of the QVC offer [that is, exercise the Lockup] rather than raise [its] bid."

Complaint of QVC at $\$ 15$, QVC Network, Inc. v. Paramount Communications, Inc., 635 A.2d 1245 (Del. Ch. 1993).

74. See infra text accompanying notes 104-08. Moreover, there is nothing at all unusual about pegging the exercise price of stock lockups at the recipient's bid.

75. We argue below that that incentive can be in the interests of target shareholders. See infra Part III.C.2.d.

76. QVC Network Inc. v. Paramount Communications Inc., 635 A.2d 1245, 1271 (Del. Ch. 1993) (emphasis added).

77. Id. at 1272; Paramount Communications, Inc. v. QVC Network, Inc., 1994 WL 3018 1, at *15 (Del. Feb. 4, 1994). 
an offer of approximately $\$ 80$ per share, an offer that was not conditioned on the lockup being enjoined. ${ }^{78}$

In sum, it appears that the lockup, viewed from the ex ante perspective, was well within the "range of reasonableness" to which courts purport to defer. ${ }^{79}$ But the Paramount II courts seem to argue, in the alternative, that the lockup became a problem, not when it was initially granted, but later, when the Paramount board failed to substantially devitalize the lockup as the bidding contest developed. The Supreme Court, for instance, argued that the Paramount board should have, when QVC made a tender offer, employed its "newlyacquired" bargaining leverage to "eliminate or modify" the lockup arrangement with Viacom. ${ }^{80}$ While the court's conclusion is clear, its reasoning is not. After all, following QVC's tender offer, the Paramount board did succeed in obtaining a substantial increase in Viacom's bid to approximately $\$ 80$ per share as well as "somewhat more flexible" provisions in the lockup. ${ }^{81}$ But there is a more subtle and powerful critique of the Supreme Court's assertion that the Paramount board could and should have bargained to modify the lockup. If this was a substantial lockup-so substantial that it "had become "draconian" and was "deterring the realization of possibly higher bids" 82 - then Paramount did not acquire any bargaining leverage over Viacom at the moment that QVC joined the auction. Rather, Viacom gained bargaining power, because it could then simply abandon a transaction that

78. As further evidence that the lockup was nonforeclosing, note that its presence did not deter Viacom from raising its own bid. See infra text accompanying notes 109-24 (explaining that a recipient bidder would not increase its own bid if the lockup is foreclosing).

79. Paramount Communications, Inc. v. QVC Network, Inc., 1994 WL 30181, at*11 (Del. Feb. 4, 1994).

80. According to the court, the Paramount board was again given the opportunity on November 15 , following another QVC bid increase, "to eliminate the restrictions they had imposed on themselves." See Paramount Communications, Inc. v. QVC Network, Inc., 1994 WL 30181, at *16 (Del. Feb. 4, 1994). Similarly, the Chancery Court observed that there was "no basis to criticize the sufficiency of the [Paramount] board's information or processes up to November 12." See QVC Network, Inc. v. Paramount Communications, Inc., 635 A.2d 1245, 1268 (Del. Ch. 1993). The Chancery Court argues that the problems with the lockup emerged not at the moment it was granted, but more than two months later and less than two weeks before the Chancery Court's opinion. In defense of the Paramount board, its reluctance to bargain with QVC in earnest after November 12 can be plausibly explained by the fact that the board was simply waiting for the Chancery Court's decision. Obviously, the question of whether the lockup provisions were enforceable was quite relevant to the question of how the Paramount board should proceed. Perhaps that explains why the Delaware Supreme Court did not pursue the Chancery Court's line of argument.

More generally, the courts' attempts to invalidate the lockup by emphasizing its effects on shareholders after it was granted may represent an unjustifiable deviation from the very sensible practice of examining the "reasonableness of the directors' actions in the light of the circumstances then existing." Paramount Communications, Inc. v. QVC Network, Inc., 1994 WL 30181, at *11 (Del. Feb. 4, 1994); see also Smith v. Van Gorkom, 488 A.2d 858, 874 (Del. 1985); Hastings-Murtagh v. Texas Air Corp., 649 F. Supp. 479, 485 (S.D. Fla. 1986) (applying Delaware law) ("[T]he validity of the [stock option] ... is reviewable only in light of the circumstances that existed and were known to the directors at the time they were adopted. Subsequent events cannot be taken into account."). 1994).

81. Paramount Communications, Inc. v. QVC Network, Inc., 1994 WL 30181, at *6 (Del. Feb. 4,

82. Id. at $* 16$. 
Viacom shareholders apparently believed was undesirable, ${ }^{83}$ and walk away with hundreds of millions of dollars. To try to induce Viacom to pay more, while reducing the value of the lockup, would seem to be a futile exercise, unless the lockup was so insubstantial in relation to the value of Paramount that it made no sense for Viacom to exercise it. But if that were the case, the Paramount board should have had no obligation to expend its newly acquired bargaining power on eliminating or reducing the lockup that, by assumption, posed no significant threat to Paramount shareholders. In short, either Paramount had little bargaining leverage, because the lockup was substantial, or it had significant leverage because the lockup was insubstantial. Regardless, the Delaware Supreme Court's criticism was without basis. ${ }^{84}$

83. Viacom's share price declined whenever Viacom appeared likely to be the "winner," indicating that Viacom's shareholders were, in effect, asking management to abandon this transaction. See Geraldine Fabrikant, Viacom's Victory: Viacom Is Winner over QVC in Fight To Get Paramount, N.Y. TiMES, Feb. 16, 1994, at A1; Paul Wiseman, Viacom Gets Paramount After 5-Month Struggle, USA TODAY, Feb. 16, 1994 , at $1 \mathrm{~B}$.

84. There is language in the opinion suggesting that a crucial element in the court's analysis was that Viacom was a corporation in which one shareholder-Sumner Redstone-held a controlling interest:

[W] hen a corporation undertakes a transaction which will cause ... a change in corporate control ...., the directors' obligation is to seek the best value reasonably available to the stockholders. This obligation arises because the effect of the Viacom-Paramount transaction, if consummated, is to shift control of Paramount from the public stockholders to a controlling stockholder, Viacom.

Paramount Communications, Inc. v. QVC Network, Inc., 1994 WL 30181, at *14 (Del. Feb. 4, 1994).

Consequently, even though the consideration to be paid to Paramount shareholders was, in part, equity securities of Viacom, the transaction was not a merger but was a sale of the company to Viacom, triggering the Revlon duty to auction. The Paramount II court's reasoning represents its attempt to distinguish the holding in Paramount II from the holding in Paramount I. In Paramount I, the court held that the merger of Time and Warner-pursuant to which Warner shareholders would end up with $60 \%$ of Time's posttransaction outstanding stock-was a merger transaction that did not trigger Revlon auction duties. The court stated that "Time's board did not by entering into its initial merger agreement with Warner come under a Revlon duty either to auction the company or to maximize short-term shareholder value, notwithstanding the unequal share exchange." Paramount Communications, Inc. v. Time Inc., 571 A.2d 1140, 1142 (Del. 1989). That is true because "there was no change of control in the original stock-for-stock merger between Time and Warner because Time would be owned by a fluid aggregation of unaffiliated stockholders both before and after the merger.” Paramount Communications, Inc. v. QVC Network, Inc., 1994 WL 30181 , at *12 (Del. Feb. 4, 1994).

The Paramount $I I$ court seems to be saying that target boards have a special duty to protect public shareholders' opportunity to receive a takeover premium. See also id. at *8 ("Once control has shifted, the current Paramount stockholders will have no leverage in the future to demand another control premium. As a result, the Paramount stockholders are entitled to receive, and should receive, a control premium and/or protective devices of significant value."). According to the Delaware Supreme Court, then, Paramount $I$ and Paramount $I I$ can be distinguished by the fact that the Paramount shareholders lost their opportunity for a takeover premium in Paramount II, whereas the Time shareholders retained their opportunity in Paramount $I$. If the distinction articulated in Paramount II is to be respected, it should mean that had Viacom been a widely held public company, the court would have enforced the lockup.

This is a surprising conclusion for at least two reasons. First, it reveals that much of what the court objected to in fairly broad terms about certain features of the lockup and about the Paramount board's failure to renegotiate the lockup would have been acceptable if only Viacom were a widely held, publicly traded corporation. Second, the court's explanation for its distinction-that is, to protect target shareholders' opportunity for a takeover premium-seems to lead to a different result than the one reached in Paramount II.

Notwithstanding the Paramount II court's suggestion to the contrary, the Time sharehoiders in Paramount $I$ appear to have lost any realistic chance of receiving a takeover premium. That is true for several reasons. First, the Time-Warner conglomerate was significantly larger than Time Inc. standing 


\section{Delaware's De Facto Relevance Rule}

In light of the strained and faulty reasoning courts have offered to justify their holdings for and against lockups, it is no surprise that legal commentators have concluded that "classifying a lock-up as a permissible type that promotes bidding, or a harmful strain that discourages bidding, appears to be no more than conclusory judicial labels that are affixed by hindsight" ${ }^{135}$ and that "judicial review [of lockups is] ... a costly, dangerous, but essentially meaningless, ritual. ${ }^{\prime 86}$

Although other scholars have noted the incoherence of Delaware's judicial analysis of lockups, they have overlooked an unstated but striking synthesizing thread that runs through and explains virtually all lockup decisions: Delaware courts have enjoined all lockups that are challenged by a nonrecipient bidder

alone, reducing the chances that it could be taken over in a hostile transaction. Second, the surviving company was, because of the merger, left with a highly leveraged capital structure, making it a less attractive takeover target even for a bidder that was not deterred by its sheer size. See Paramount Communications, Inc. v. Time, Inc., 571 A.2d 1140, 1155 (Del. 1989). Third, it seems to have been the marketplace's perception that Time had substantially overpaid for Warner, making the combined enterprise even less attractive to a potential buyer. The validity of these points is underscored by the fact that if Paramount had not believed that Time had ovepaid for Warner, it would not have made its offer for Time contingent on the abandonment of the acquisition of Warner. Instead, it would have acquired the combined enterprise and sold Warner either at a profit, on a break even basis or, perhaps, at a small loss. In addition to those demand-side reasons for why the shareholders of Time, Inc. effectively lost any opportunity to receive a control premium, there exists an important supply-side reason. Even if there were potential buyers, it would seem unlikely that the Time-Warner board would have had any interest in selling. So long as the Time-Warner board did not put the company up for sale, and thereby trigger Revlon duties, the board would have no clear legal obligation under Delaware Law to sell the company. Thus, in Paramount 1 , the Delaware court appeared to justify preventing target shareholders from enjoying a substantial takeover premium (approximately $\$ 75$ per share) on the basis that those shareholders might have a subsequent opportunity to enjoy such a premium, when that belief appears to have been counter factual.

The Delaware courts' concern that enforcing the lockup in Paramount II would have eliminated the chance that Paramount shareholders would ever receive a takeover premium also seems misplaced. First, it seems no less likely that a third-party bidder would purchase the Paramount-Viacom entity than it was that a third party would purchase the Time-Warner entity. The Delaware court should take the former possibility as seriously as it takes the latter possibility. Second, precisely because the combined entity would be controlled by a single shareholder, there is less reason to fear that the board of the ViacomParamount entity would resist a value-increasing sale. Randall Morck et al., Characteristics of Targets of Hostile and Friendly Takeovers, in CORPORATE TAKEOVERS: CAUSES AND CONSEQUENCES 101 (Alan J. Auerbach ed., 1988) (providing evidence that the likelihood of a wealth-enhancing takeover decreases, and the percentage of hostile takeovers increases, as a management's stock ownership decreases); Ralph A. Walkling \& Michael S. Long, Agency Theory, Managerial Welfare, and Takeover Bid Resistance, 15 RAND J. ECON. 54 (1984) (same). Third, the Delaware's Supreme Court's concern that Redstone could freeze out minority shareholders, to take all of the takeover gains for himself, ignores the substantial body of Delaware case law that protects minority shareholders in freeze out situations. See generally In re Weinberger v. UOP Inc., 457 A.2d 701 (Del. 1983). Additionally, Delaware law provides for an appraisal remedy that is administered by the Delaware courts. So, unless the Delaware Supreme Court believes that the "entire faimess doctrine" as articulated in Weinberger ineffective, and further believes that the appraisal remedy is ineffective, there would seem to be no justification for this particular distinction. But even if there was no way to ensure that Paramount shareholders would still have the opportunity for a takeover premium after its acquisition by Viacom, that does not necessarily mean that they have been deprived of their right to a takeover premium. Quite the contrary. Had the lockup been enforced, the shareholders would have received a substantial takeover premium, as the facts of the case indicate.

85. Herzel et al., supra note 17 , at 177 .

86. Bainbridge, supra note 1 , at 283. 
who has made a higher bid contingent upon invalidation of the lockup, and have enforced all lockups where no such competing bid exists. ${ }^{87}$ However, only lockups of the former category are of importance to shareholder interests: A lockup unchallenged by nonrecipient bidders, the latter category, is tantamount to no lockup at all. Thus, while courts claim to enforce lockups that are compensatory and invalidate those that are not, they in fact invalidate all those that are serving their intended purpose and enforce only those that are not.

Thus, Delaware's express standard, which recognizes that effective lockups can be loyal, is in fundamental tension with its de facto rule, which treats all effective lockups as disloyal. That tension stems from the fact that courts would like (and claim) to be able to distinguish loyal from disloyal lockups, but cannot. Confronted with the dilemma of either enforcing all lockups, including disloyal lockups, or enjoining all lockups, including loyal lockups, Delaware courts have-in a way that is facially consistent with the view that some lockups are loyal-taken the second option.

\section{The Ex Post Approach}

Recently, some corporate law scholars have purported to resolve that dilemma by offering courts a means of deterring only disloyal lockups. ${ }^{88} \mathrm{As}$

87. See, e.g., Revlon, 506 A.2d at 173 (enjoined); Mills Acquisition v. Macmillan, 559 A.2d 1261 (Del. 1989) (same); Hanson Trust PLC v. ML SCM Acquisition Inc., 781 F.2d 264 (2d Cir. 1986) (same); Paramount Communications, Inc. v. QVC Network, Inc., 1994 WL 30181 (Del. Feb. 4, 1994) (same); In re Frederick Rand v. Western Air Lines Inc., No 8632, 1994 Del. Ch. LEXIS 26 (Del. Ch. 1994) (enforced); Repairman's Serv. Corp. v. National Intergroup, Inc., 10 DEL. J. CORP. L. 902 (Del. Ch. Mar. 15, 1985) (same); In re KDI Corp. Shareholders Litig., No. 10,278, 1988 Del. Ch. LEXIS 143 (Del. Ch. Nov. 1, 1988) (same); Braunschweiger v. American Home Shield Corp., 1989 Fed. Sec. L. Rep. (CCH) II 94,779 (Del. Ch. Oct. 26, 1989) (same); Roberts v. General Instrument Corp., 1990 Fed. Sec. L. Rep. (CCH) II 95,465 (Del. Ch. Aug. 13, 1990) (same); Thompson v. Enstar Corp., 509 A.2d 573 (Del. Ch. 1984) (same); Hecco Ventures v. Sea-Land Corp., 1986 WL 5840 (Del. Ch. May 19, 1986) (same); Yanow v. Scientific Leasing, Inc., 1991 Fed. Sec. L. Rep. (CCH) II 96,189 (Del. Ch. July 31, 1991) (same); In re J.P. Stevens \& Co. Shareholders Litig., 542 A.2d 770, $781-84$ (Del. Ch. 1988) (same); cf. Bainbridge, supra note 1 , at 300 ("[C]ourts have upheld auction-ending provisions in practice, admittedly most often where no one appears willing to top the favored bidder's offer."). On two occasions, one very recent, the Delaware courts have included a board's grant of a lockup as one of a large number of factors justifying rulings in favor of plaintiffs in personal liability actions brought against directors in breach-of-duty, breachof-care shareholder-directive suits. See generally Cede \& Co. v. Technicolor, Nos. 336 \& 337, 1993 Del. LEXIS 398 (Del. Oct. 22, 1993); Smith v. Van Gorkom, 488 A.2d 858 (Del. 1985). Those actions were filed after mergers were complete and the lockups at issue were not enjoined. In those cases, the focus of the litigation was not on the validity of the lockups, but on the degree of care and loyalty displayed by target boards.

88. These scholars can be understood as preferring a rule to Delaware's proportionality standard. $C f$. MARK KELMAN, A GUIDE TO CRITICAL LEGAL STUDIES 17 (1987) ("In every dispute about the appropriate resolution of a legal controversy, rule-like solutions, standard-based solutions, and intermediate positions will uncomfortably coexist, none fully dominating either day-to-day practice or a fortiori justificatory rhetoric."); Duncan Kennedy, Form and Substance in Private Law Adjudication, 89 HARv. L. REv. 1685, 1701 (1976) ("There seems no basis for disputing that the notions of rule and standard, and the idea that the choice between them will have wide-ranging practical consequences, are useful in understanding and designing legal institutions."). 
adumbrated above, those scholars have proposed an ex post approach which ostensibly would rely on the market for corporate control rather than on courts to identify and eliminate inefficient corporate arrangements. ${ }^{89}$

\section{Stephen Bainbridge's Ex Post Approach}

Stephen Bainbridge's recent article on lockups, in which he purports to propose "a more coherent and workable framework for judicial review of ... lock-ups," exemplifies the ex post approach. ${ }^{90}$ Bainbridge argues that "the validity and enforceability of a lockup should hinge on the likelihood that it is being used to protect side payments to management." potential conflict of interest that may taint a decision to grant ... a lockup" ${ }^{\text {"92 }}$ and to "avoid [] the need to resolve subjective and complex questions of motive," for judicial review" ${ }^{\text {"44 }}$ by asking only whether a lockup is foreclosing (or whether, in his words, the lockup "precludes competitive bidding"95). Bainbridge nowhere attempts to specify which lockups are foreclosing and which, nonforeclosing. Instead, he proposes a "bright-line" rule, according to which courts would invalidate any lockup that guarantees the recipient bidder more than "ten percent of the value of the favored bidder's proposal," unless the target board granted the lockup after conducting a "voluntary control auction subject to judicial review of the procedures." ${ }^{.96}$ Smaller lockups would be subject to the scrutiny of only the business judgment rule. ${ }^{97}$ Bainbridge's proposal is similar to that of other scholars and policy analysts who propose the same sort of threshold requirement. ${ }^{98}$

89. See supra Part II.A.

90. Bainbridge, supra note 1 , at 252 .

91. Id. at 291; see also id. at 251 ("[T]he validity of . . . lock-ups should turn on whether a given provision deters competing bids.").

92. Id. at 289.

93. Id. at 291.

94. Id.

95. Id. at 289.

96. Id. at 332; see id. at 327-32; see also infra notes 166-70 and accompanying text (describing problems with Bainbridge's auction requirement). Alternatively, Bainbridge could have proposed that large lockups all be enforced, but only up to $10 \%$ of the value of the recipient's bid.

97. Id. at 323-24.

98. See, e.g., SEC Advisory Committee on Tender Offers, Report of Recommendations 44 (1983), reprinted in [Extra Ed. No. 1028] Fed. Sec. L. Rep. (CCH) (July 15, 1983) (requiring "that during a tender offer the issuance of stock representing more than $15 \%$ of the fully diluted shares that would be outstanding after issuance should be subject to shareholder approval"); Johnson \& Siegel, supra note 1, at 318-19 (asserting that "shareholders' interests in merger transactions would best be served by legal rules ensuring the unfettered operation of a structural and market monitors"; the structural monitor is the "shareholder vote" which purportedly "can police both the motives and the wisdom of a target board's resolution recommending a merger," and the market monitor is the "marketplace" which purportedly "can provide alternate choices for shareholders in the form of competing merger proposals or tender offers"); id. at 40910 (proposing that stock options be limited to $15 \%$ of the target's outstanding shares and asset options to $15 \%$ of its assets). 
A problem with such proposals is that there is no reason to believe that the bright-line threshold coincides with the line between foreclosing and nonforeclosing lockups. Bainbridge's ten percent rule would serve its desired purpose only where (1) a lockup of ten percent or less would be nonforeclosing, (2) the lockup at issue exceeds ten percent of the value of the recipient bidder's proposal, (3) the lockup is foreclosing, and (4) the target board granted the lockup for disloyal reasons. If a lockup of ten percent or less would be foreclosing, Bainbridge's rule would be underinclusive and would serve only as a safe harbor to boards who grant disloyal, ten percent lockups. If a lockup that exceeds the ten percent threshold would be nonforeclosing, Bainbridge's rule would be overinclusive. In such cases, the target board would have to waste substantial resources in order to conduct a "voluntary control auction." 99 Finally, if a lockup that exceeds the threshold would be foreclosing but not supracompensatory from an ex ante perspective, Bainbridge's rule would again be overinclusive and would prevent target boards from acting in the interest of target shareholders. ${ }^{100}$

Bainbridge at one point concedes that his is an arbitrary rule "that in some cases . . . will not capture [foreclosing] lock-ups and in others . . . will allow them," but maintains that the benefits of "certainty" that his bright-line rule would provide outweigh the costs of over- and underinclusion. ${ }^{101}$ To the contrary, however, the benefits of certainty-whatever they might be and however they might be measured-seem likely to be slight. As we have argued, Bainbridge's rule will often be either underinclusive or overinclusive. Where overinclusive, the rule will increase the costs to faithful boards, either by forcing them to jump through costly procedural hoops or by taking from them the benefits of lockups. Where underinclusive, the rule will protect disloyal

99. See Bainbridge, supra note 1, at 328-32 (describing some of the details of the auction requirement); see also id. at 317 ("Forcing unwilling directors to conduct an effective auction is extremely difficult."). If Bainbridge did not believe that the costs of conducting voluntary control transactions would be substantial, he would simply have made that the requirement in all cases, regardless of the size of the lockup.

100. We consider this last possibility-that foreclosing lockups may be loyal lockups-below. See infra Part II.C.3.

101. Bainbridge, supra note 1 , at 324; see also id. at 323 ("Admittedly, there is some risk that the standard will be underinclusive . . . or overinclusive . . . Gains from enhanced certainty, however, should overcome those costs."); id. at 281 ("[U]ncertainty results from the rarity of decisions and the lack of uniformity among jurisdictions that have addressed this issue. . . . [and] uncertainty is inherent in the very nature of the inquiry"); $i d$. at 282 ("The present uncertainty as to the validity of exclusivity provisions and lock-ups produces important social costs. If uncertainty causes parties to not enter into exclusivity provisions or lock-ups when the provision, in fact, would benefit shareholders, socially desirable behavior is deterred. However, uncertainty also prevents optimal deterrence because target boards may believe that they can validly enter socially undesirable provisions. Courts can alleviate this problem, at least in part, by adopting bright-line standards that clearly define when target boards can validly enter exclusivity provisions."). Bainbridge's suggestion that bright-line standards would have beneficial deterrence effects misses the mark. Clearly defined standards will have harmful deterrence implications if target boards can, with certainty, enter socially undesirable lockups or cannot, with certainty, enter into socially desirable lockups. Bainbridge offers several other justifications for a threshold of $10 \%$, none of which are responsive to these criticisms. Id. at 324 . 
arrangements at the expense of target shareholders. That these results are certain is hardly a plus. But, even assuming that there are benefits to certainty, Bainbridge offers no good reason to prefer his bright-line rule over any number of alternative bright-line rules.

Indeed, it seems a rule that would enforce all lockups would be clearly superior to Bainbridge's ten-percent rule because it provides at least as much "certainty" and is less costly to administer. This is an argument we take up in greater detail in Part III, but doing so requires that we first examine the ex post approach of Ian Ayres, whose work has strongly influenced our own.

\section{Ian Ayres' Ex Post Approach}

Offering by far the most sophisticated and illuminating economic analysis of lockups to date, Ian Ayres has recently proposed a standard with which courts might distinguish foreclosing from nonforeclosing lockups. ${ }^{102}$ To understand Ayres' proposed standard, it is useful first to understand certain basic conclusions that follow from his analysis. ${ }^{103}$

A lockup is nonforeclosing, recall, when it has no potential effect on who wins an auction. Ayres was the first to recognize that some lockups will have no foreclosing effect-or, put differently, will have no effect on the relative valuations of the target by potential bidders. Ayres' key insight is that, because the recipient bidder would profit from the lockup itself only by losing the target to a higher bidder ${ }^{104}$ (that is, because winning the target would entail the opportunity cost of not profiting from the lockup), the lockup reduces the recipient bidder's valuation or reservation price. ${ }^{105}$ Of course, as courts and commentators have long recognized, a stock lockup also reduces the reservation price of third-party bidders to the extent it dilutes the value of the target's outstanding shares. ${ }^{106}$ But, as Ayres makes plain, although a lockup will reduce the reservation price of third-party bidders, the lockup will not necessarily foreclose those bidders from competing with the recipient bidder:

102. See generally Ayres, supra note 9.

103. Following Ayres' lead, we shall, for ease of exposition, focus primarily on stock lockups, but our analysis, like Ayres', applies equally to other types of lockups. See Ayres, supra note 9, at 714-15 (analyzing asset lockups); see also infra note 126. Stock lockups are the most common form of lockup. See Note, Lock-Up Options, supra note 17, at 1068.

104. Ayres, supra note 9, at 688. Prior to Ayres' work on the topic, courts and scholars seem not to have understood that insight. See id. at 693 . There is evidence, however, that some courts are now beginning to understand it. See QVC Network Inc. v. Paramount Communications Inc., 635 A.2d 1245 (Del. Ch. 1993).

105. Ayres, supra note 9, at 686-94; see also id. at 693 ("By purchasing treasury shares, a bidder effectively promises to drop out of subsequent auctions at a price below jts subjective valuation."). In contrast, a bidder's open market purchases of target stock should not reduce the bidder's reservation price, because the bidder will profit from those purchases regardless of who wins the auction. Id.

106. Id. at 694 (explaining how selling "additional treasury shares at a price that does not include the post-merger synergistic value effectively 'dilutes' the synergistic value of the outstanding shares, and thus reduces the maximum amount that a third party would be willing to bid"). 
The dilution cost imposed on third-party bidders is equal to the opportunity cost imposed on the recipient bidder. Hence, "the sale of treasury stock lowers the reservation price of all bidders but does so equally."107 Any higher valuing third-party bidders will outbid the recipient bidder, notwithstanding the lockup. ${ }^{108}$ To see this point, consider Figure 1 .

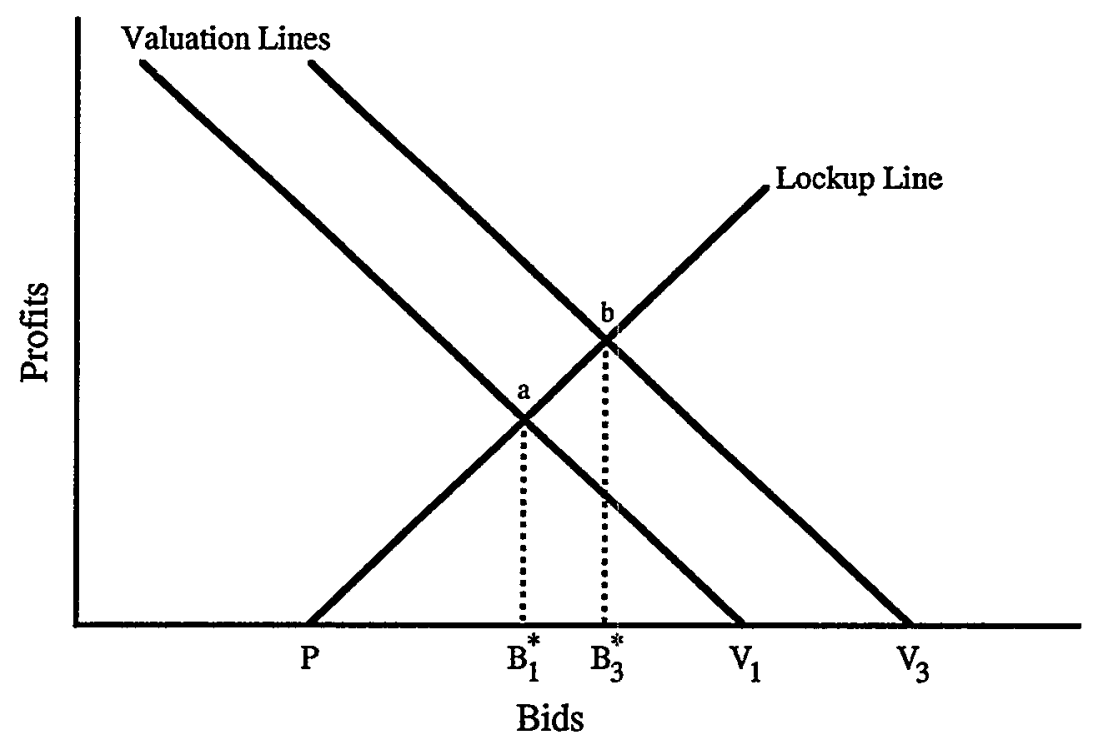

FIGURE 1. A Lockup's Effect on Reservation Prices

The valuation lines in Figure 1 measure the bidders' takeover profits as the per-share bid increases. ${ }^{109}$ Before any lockup is granted, the intersection of the recipient bidder's ("Bidder 1's") and the third-party bidder's ("Bidder 3's") valuation lines with the horizontal axis measures the bidders' per share reservation prices, $V_{I}$ and $V_{3}$, respectively. ${ }^{110}$ After a lockup is granted to

107. Id. at 695; see also infra note 113 (explaining that reservation prices are reduced proportionately. not equally).

108. Ayres, supra note 9, at 695 .

109. A bidder's valuation line intercepts the horizontal axis at the bidder's reservation price and has a slope of negative one.

110. We have attempted, where possible, to employ Ayres' notation. Ayres, supra note 9. The basic notation employed throughout the remainder of the Article is as follows:

$V_{1}=$ Bidder 1's (i.e., the recipient bidder's) pre-lockup, per-share reservation price;

$V_{3}=$ Bidder 3's (i.e., the nonrecipient bidder's) pre-lockup, per-share reservation price;

$B_{i}^{*}=$ Bidder l's post-lockup, per-share reservation price;

$B_{3}^{*}=$ Bidder 3's post-lockup, per-share reservation price;

$B_{1}=$ Bidder l's per-share bid;

$B_{3}=$ Bidder 3's per-share bid;

$N=$ number of original outstanding shares;

$T=$ number of treasury shares optioned; 
Bidder 1, however, the bidders' reservation prices $-B_{1}{ }^{*}$ and $B_{3}{ }^{*}$, respectively-are measured by the intersection of their valuation lines with the lockup line. ${ }^{11}$ The lockup line measures the minimum amount that Bidder 1 would receive from the lockup or, in other words, that Bidder 3 would have to pay to Bidder 1 were Bidder 3 to win the auction. Bidder 1 is unwilling to bid more than $B_{t}{ }^{*}$ after the lockup because for any competing bid greater than $B_{l}^{*}$, Bidder 1 will profit more by losing than by winning the auction. ${ }^{12}$ Bidder 3 will be unwilling to bid more than $B_{3}{ }^{*}$ because, for any bid greater than $B_{3}{ }^{*}$, Bidder 3 would lose more to Bidder 1 via the lockup than it would gain from winning the target.

Notice that although the lockup reduces the reservation prices of both bidders, it does not affect their relative valuations. That is, Bidder 3 still has a higher reservation price than Bidder 1 (i.e., $B_{3}{ }^{*}>B_{1}{ }^{*}$ ). ${ }^{113}$ Assuming Bidder 3 is not somehow foreclosed, Bidder 3 will outbid Bidder 1 for the target notwithstanding the lockup. ${ }^{114}$ Thus, lockups do not, by themselves, affect bidders' ordinal valuations. ${ }^{115}$

$P \quad=\quad$ per-share exercise price of treasury shares optioned.

111. A lockup line intersects the horizontal axis at the per-share exercise price of the lockup option and has a positive slope that increases as the number of treasury shares optioned increases.

112. If, as seems unlikely, Bidder 1 knew Bidder 3's reservation price, Bidder 1 would bid up to $B_{3}$ * in order to maximize its profits from the lockup. We will assume, as have others analyzing lockups, that only a bidder knows its own reservation price. We briefly relax that assumption below. See infra text accompanying notes $277-79$.

113. Ayres indicates that the reservation prices are reduced "equally" by the lockup. Ayres, supra note 9, at 695. More accurately, the reservation prices are reduced proportionately, not equally, as can be seen from the fact that Triangle $B_{,}{ }^{\circ} a V$, is similar (in the geometrical sense of the word) to but smaller than Triangle $B, b V_{3}$. This trivial qualification does not affect Ayres' important conclusion that the lockup has no effect on ordinal reservation prices.

114. Below we explain how a lockup might preclude a higher valuing bidder from an auction. See infra Part III.B.2.

115. It will be useful here to review Ayres' algebraic rendition of this point so that we can expand upon it below. Ayres, supra note 9. The profits to Bidder 1 from winning the target are:

(1) $\left(V_{1}-B_{1}\right) N$,

where $B_{1}$ is Bidder l's bid and $N$ is the number of original outstanding target shares. Bidder l's profits from losing the target to Bidder 3 equal:

(2) $\left(B_{3}-P\right) T$,

where $B_{8}$ is Bidder 3's bid, $P$ is the option price on the treasury shares, and $T$ is the number of treasury shares optioned. Bidder $1^{\prime}$ 's reservation price after the lockup is granted, $B, ;$, can be obtained by setting equation (1) equal to equation (2) and solving for a common $B$, corresponding to the intersection of Bidder I's valuation line and the lockup line in Figure 1, the point at which Bidder 1's profit from winning equals its profit from losing:

(3) $B_{i}^{\circ}=\left(V_{i} N+P T\right) /(N+T)$.

(Equation (3) confirms the intuition that, as either the price of treasury shares, $P$, decreases or the number of treasury shares, $N$, increases, Bidder l's maximum bid after the lockup will decrease.) Before receiving the lockup, Bidder 1 would be willing to bid $V$, per share for the target. But, as depicted in Figure 1, a lockup reduces Bidder l's reservation price because $B_{i}{ }^{*}$ will always be less than $V_{i}$ :

(4) $V_{1}-B_{i}^{*}=T\left(V_{1}-P\right) /(N+T)>0$.

This assumes uncontroversially that $V_{1}>P$. If $V_{1}<P$, then the lockup would be nonforeclosing and would not reduce-and might even increase, see infra note 261 -the recipient's reservation price.

The profits to Bidder 3 from winning the target before the lockup is granted to Bidder 1 are: (5) $\left(V_{3}-B_{3}\right) N$.

After the lockup, Bidder 3 would have to pay the following amount to Bidder 1:

(6) $\left(B_{3}-P\right) T$. 
Whether a lockup is foreclosing depends also on the size of the recipient's bid given in exchange for the lockup. To see this, suppose, as shown in Figure 2, that Bidder 1 offers to bid $B_{l}^{\prime}$ for the target in exchange for a lockup. Depending on the terms of the lockup, Bidder 1's ex post reservation price may be greater than, less than, or equal to $B_{l}{ }^{1}$. The three possibilities are depicted in Figure 2.

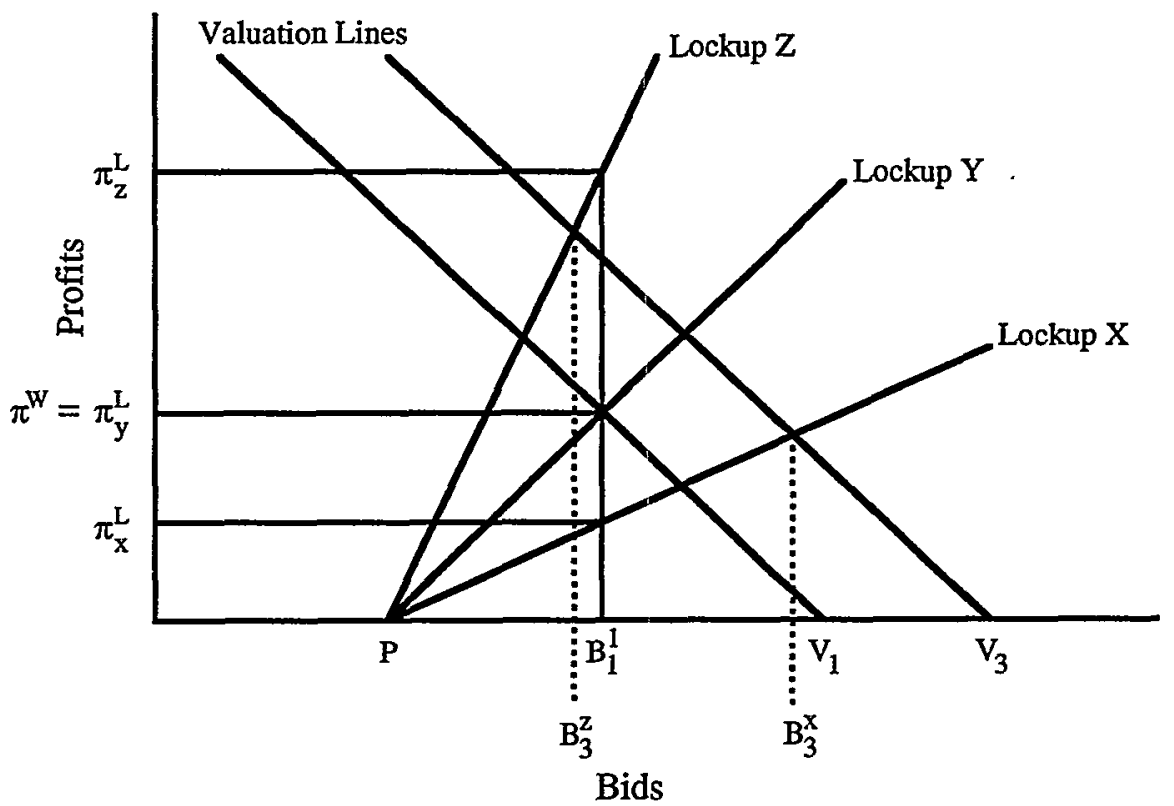

FIGURE 2. The Foreclosing Effects of Lockups

Lockup $X$ is nonforeclosing because any higher valuing bidder (e.g., Bidder 3 with valuation $V_{3}$ ) would be willing to pay up to $B_{3}{ }^{x}\left(>B_{1}{ }^{\prime}\right)$. Bidder 1 clearly prefers winning to losing the auction after Lockup $X$ is granted because $\pi^{W}$, Bidder 1's profit from winning at its bid, ${ }^{116}$ is greater than $\pi_{x}{ }^{L}$, Bidder 1's profit from losing at its bid. ${ }^{117}$ A nonforeclosing lockup will therefore have no effect on who wins the auction, although it may affect the

Bidder 3's reservation price after the lockup is granted, $B_{3}{ }^{*}$, can thus be obtained by setting equation (5) equal to equation (6) and solving for a common $B$, corresponding to the intersection of Bidder 3's valuation line and the lockup line in Figure 1: (7) $B_{3}{ }^{*}=(V, N+P T) /(N+T)$.

A lockup reduces Bidder 3 's reservation price, because $B_{3}{ }^{\circ}$ will always be less than $V_{3}$ just as with Bidder 1. But, comparing equation (3) with equation (7), it is clear that $B_{i}{ }^{*}$ will always be less (greater) than $B_{i}{ }^{*}$ whenever $V_{1}$ is less (greater) than $V_{3}$. Again, lockups do not, by themselves, affect bidders' relative valuations.

116. That is, $\left(V_{1}-B_{1}\right) N$.

117. That is, $\left(B_{i}^{\prime}-P\right) T$. 
size of the winning bid. As Ian Ayres puts it: "Consistent with basic tenets of efficiency, the ownership of corporate assets will travel to the highest valuer, but the treasury sale reduces the per share bid that wins the auction." 118 In this same way, any lockup that intersects Bidder 1's valuation line at or to the right of $B_{1}^{\prime}$ will be nonforeclosing. ${ }^{119}$ Nonforeclosing lockups, therefore, will not protect disloyal efforts to entrench incumbent management. Thus, as Ayres concludes, Delaware courts should apply the business judgment rule to nonforeclosing lockups. ${ }^{120}$

Lockup $Y$ is the largest nonforeclosing lockup that the target can grant. Put differently, given Lockup Y, $B_{l}^{\prime}\left(=B_{l}^{*}\right)$ is the most that Bidder 1 can bid without potentially foreclosing higher valuing bidders. Ayres refers to this sort of lockup arrangement as an "auction insurance" lockup because it guarantees that Bidder 1 profits the same amount from losing the auction (i.e., $\pi_{y}^{L}$ ) as Bidder 1 expected to earn from winning (i.e., $\pi^{W}$ ). ${ }^{121}$ We shall refer to such a lockup as an "expectancy lockup."

There exists a second class (an "extreme form"122) of lockup arrangement, however, that Ayres believes courts should enjoin:

If the treasury shares insure more than $100 \%$ of [the] takeover risk, ... foreclosure of third-party bidders is possible. Higher-valuing bidders may be foreclosed if the target company guarantees that the recipient of treasury shares will profit more from losing the auction (and tendering its shares) than from winning the auction at its initial bid. ${ }^{123}$

Lockup Z, for example, is foreclosing, because some higher valuing bidder (e.g., Bidder 3) may be unwilling to match the bid of $B_{l}{ }^{\prime}$, (i.e., $B_{1}{ }^{\prime}>B_{3}{ }^{2}$ ). Note that Bidder 1 prefers losing to winning the auction after Lockup $\mathrm{Z}$ is granted because $\pi_{z}^{L}$, Bidder 1's minimum profits from losing, exceed $\pi^{W}$, Bidder 1's profits from winning. In this way, any lockup that intersects Bidder 1's valuation line to the left of Bidder 1's initial bid, $B_{l}^{\prime}$, will thus be "foreclosing," as Ayres defines the term. ${ }^{124}$ A loyal management would not, according to Ayres, contract for a lockup that provides more than a Bidder's

118. Ayres, supra note 9 , at 695 .

119. That is, any time $B_{l}^{\prime}<B_{l}^{\circ}$, the lockup will be nonforeclosing.

120. Ayres, supra note 9, at 707. For a possible exception to this result, see infra Part III.B.2.

121. Ayres, supra note 9, at 699-700.

122. Id. at $684,699,715$.

123. Id. at 699-700; see also id. at 701 ("[F]oreclosure stems from the unwillingness of third parties to match the initial offer.").

124. See id. at 702 (showing algebraically). 
expectancy. ${ }^{125}$ Thus, Ayres proposes that courts enjoin all greater-thanexpectancy lockups. ${ }^{126}$

While Ayres' most fundamental insight-that some lockups have no foreclosing effect-is important and persuasive, we disagree with key portions of his analysis as well as with his policy conclusions. One problem with Ayres' proposed standard-aside from the possibility that courts may be unable to accurately and practicably apply it-is that it only distinguishes nonforeclosing (i.e., not potentially foreclosing) lockups from potentially foreclosing lockups. According to Ayres' reasoning, however, some potentially foreclosing lockups should not be invalidated. A lockup can provide more than a bidder's expectancy, and thus potentially foreclose some bidders, but still not actually foreclose the highest valuing bidder. ${ }^{127}$ Such potentially, but not actually, foreclosing lockups we shall refer to as "partially foreclosing." Assuming Bidder 1 is the recipient bidder and Bidder 3 is the highest valuing bidder, any lockup larger than Lockup $Z_{p}$ in Figure 3 or smaller than Lockup $\mathrm{Z}_{i}$ is partially, but not fully, foreclosing. ${ }^{128}$

125. Id. at 684 (asserting this type of "foreclosure is inconsistent with maximizing shareholder welfare"); $i d$. at 703 ("[F]aithful management would not contract for this much insurance."). But see infra notes 163-65 and accompanying text (describing Ayres' concession that a greater-than-expectancy lockup can be loyal) and Part III.C.2-3 (suggesting reasons why loyal managers would contract for more than their expectancy).

126. Ayres, supra note 9 , at 704 (recommending that "courts . . invalidate agreements in which they determine that the treasury shares provide more than $100 \%$ insurance"). This analysis applies as well to asset lockups. Where a target's asset is optioned in a lockup to the bidder at a discount, the recipient will have incentives analogous to those of the recipient of a treasury-share lockup. The recipient of the asset lockup will be guaranteed a profit from losing, which will represent the opportunity cost of winning. As with treasury share lockups, third-party foreclosure is possible if the recipient of the asset lockup can profit more from losing the contest (and exercising the option) than from winning the contest at the initial bid. id. at 714-15.

127. Put differently, to say that $B_{1}^{\prime}>B_{1}$, does not imply that $B_{1}^{\prime}>B_{3}$.

128. One lockup is "greater than" another either if it includes more treasury shares $(T)$ or if the exercise price $(P)$ of the treasury shares that it does include is lower, other things equal. The foreclosing effect of lockup arrangements will also vary according to the recipient bidder's bid, $B_{\prime}^{\prime}$. For purposes of illustration, we have held $P$ and $B_{l}^{\prime}$ constant and allowed the quantity of shares to vary in the figures. 


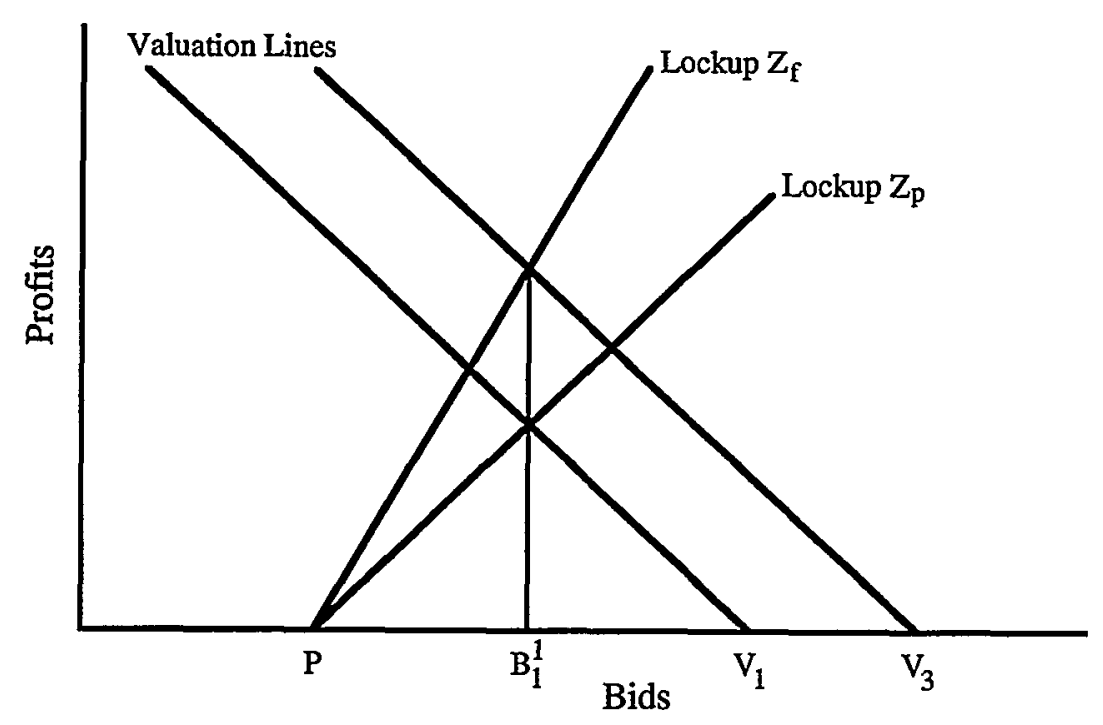

FIGURE 3. Partially and Fully Foreclosing Lockups

Bidder 3 will outbid the recipient bidder, notwithstanding a partially foreclosing lockup. Thus, for the same reason that nonforeclosing lockups should be enforced (subject only to the business judgment rule), partially foreclosing lockups should be enforced. Where a lockup does not foreclose higher valuing bidders, it cannot successfully serve to entrench target managers and thus does not create any heightened threat to shareholder interests. ${ }^{129}$ Thus Ayres' standard, in its purest form, would be overinclusive. ${ }^{130}$

A second general problem with Ayres' proposed standard is that, even if all potentially foreclosing lockups should be invalidated, the theoretical distinction between potentially foreclosing and nonforeclosing lockups is of little practical value. Recall that for a lockup to be foreclosing, it must ensure the recipient bidder greater profits from losing the auction than from winning. Although courts can probably measure the bidder's expected gains from losing, ${ }^{131}$ they cannot measure the bidder's expected gains from winning

129. See supra notes 18-21 and accompanying text. Ayres bases his proposal on the assumption that even partially foreclosing lockups are disloyal, even if not fully foreclosing. But see infra notes 163-65 and accompanying text (describing Ayres' concession that foreclosing lockups can be loyal) and Part III.C.2-3 (explaining why loyal boards might grant foreclosing lockups).

130. Note that Ayres' analysis has some practical value insofar as it provides courts some clear-cut means of recognizing nonforeclosing lockups, which should always be enforced. See infra note 176.

131. The profits from a stock lockup can be determined by multiplying the difference between the recipient bidder's per-share bid and the lockup's per-share exercise price by the number of treasury shares at stake (i.e., $(B-P) T$ ). However, the same calculation would be far more complicated for asset lockups-a point that Ayres does not mention-because courts have no dependable way of measuring the assets' pre-bid market price. Bainbridge, whose proposal would also require that "[c]ourts . . . measure the value of asset 
unless they know a bidder's reservation price (i.e., $V_{l}$ ), knowledge which seems beyond the ken of most courts. Indeed, if courts could easily and accurately assess bidders' reservation prices, they would not call for auctions. ${ }^{132}$ Viewed in this light, therefore, Ayres' proposed standard, which was intended to be a "straightforward" and "practical"133 alternative to Delaware's ex ante approach, appears to recreate the very problems it was designed to solve. Because courts have no accurate test for identifying potentially foreclosing lockups, the problems of underinclusiveness and overinclusiveness that would plague Bainbridge's proposed rule would likewise plague Ayres' proposed standard. ${ }^{134}$ That is, if courts overestimate the extent of a lockup's foreclosure, they will wrongly invalidate nonforeclosing lockups. If, on the other hand, they underestimate, they will fail to invalidate foreclosing lockups.

In anticipation of the second criticism, Ayres offers a modified version of his proposal. ${ }^{135}$ Acknowledging that courts cannot measure a bidder's expected benefits "with precision,"136 he argues that courts should nevertheless invalidate lockups that are unmistakably foreclosing. ${ }^{137}$ More specifically, courts should ask: First, if this were the largest nonforeclosing lockup that the target could grant, given the bid (see Lockup Y in Figure 2, supra), what would that imply about the recipient's valuation? And second, is the valuation implied (that is, the "requisite valuation" or $V_{R}$ ) within "the reasonable range of possible valuations"? ${ }^{138}$ Where it would "stretch the imagination to conceive that [the recipient bidder] valued the firm that much," 139 the lockup is unmistakably foreclosing and should, according to Ayres, be invalidated.

lock-up options by the appraised fair market value of the assets in question," concedes that "[v]aluation of asset lock-ups can be a most difficult issue for courts," for which there is no perfect solution. Bainbridge, supra note 1 , at 325 \& n.359.

132. See infra text accompanying notes $270-72$ (explaining how auctions reveal bidders' valuations).

133. Ayres, supra note 9 , at 684,715 .

134. See supra notes $99-101$ and accompanying text.

135. Ayres, supra note 9, at 704-05. Although Ayres nowhere discusses the first criticism, it is perhaps not a coincidence that his response to the second criticism is partially responsive to the first.

136. Id. at 704 .

137. See id. at 705 .

138. Id. Algebraically, determining a recipient bidder's requisite valuation $\left(V_{R}\right)$ involves assuming that the recipient bidder will profit the same amount from losing the contest for the target as from winning:

(8) $\left(B_{f}^{\prime}-P\right) T=\left(V_{R}-B_{l}{ }^{\prime}\right) N$, and then solving for $V_{R}$ :

139. Id.

(9) $V_{k}=\left(T B_{i}^{\prime}+N B_{i}^{\prime}-T P\right) / N$. 


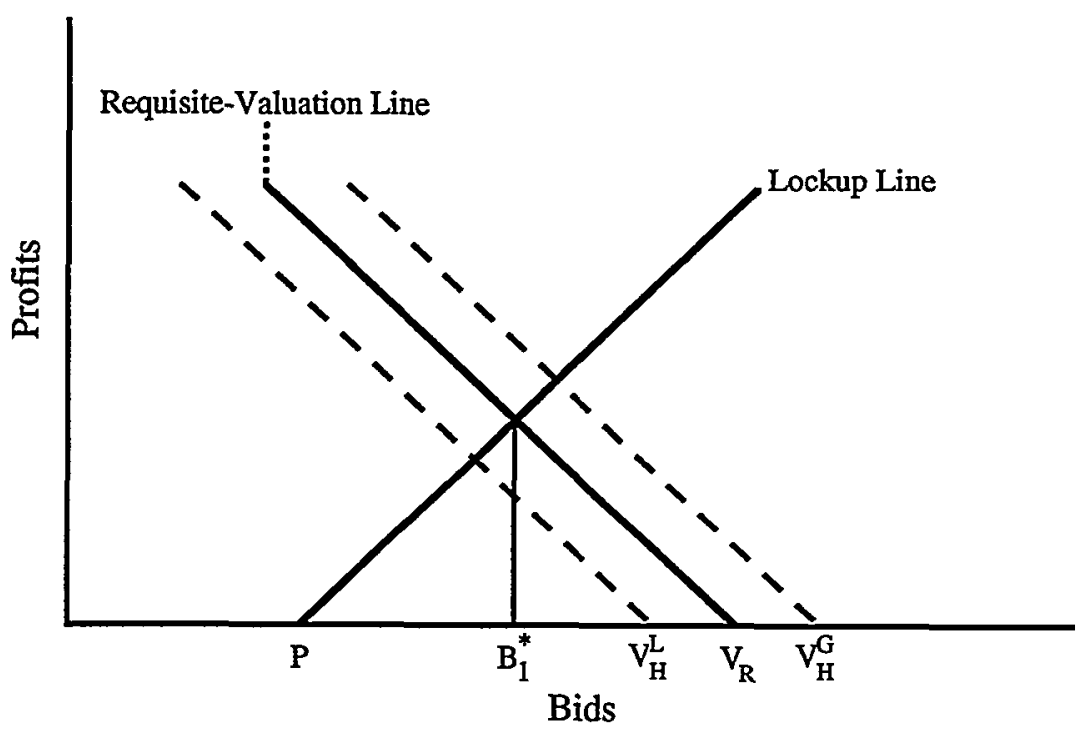

FIGURE 4. Measuring a Lockup's Foreclosing Effect

In terms of Figure 4, if the court concludes that the highest possible valuation, $V_{H}$, is $V_{H}{ }^{G}$ (such that $V_{H}{ }^{G}>V_{R}$ ), then the court should enforce the lockup. If instead the court estimates that the highest possible valuation is $V_{H}{ }^{L}$ (such that $V_{H}{ }^{L}<V_{R}$ ), then the court should invalidate the lockup. Again, that is true, according to Ayres, because any lockup that has an implied reservation price beyond the range of reasonableness must be the work of a target board attempting disloyally to purchase job security at the expense of target shareholders. ${ }^{140}$

But Ayres' modified standard also lacks talismanic precision. In order to determine whether the requisite valuation associated with a particular lockup "exceeds the range of reasonable valuations," courts must have some sense of where the margin of reasonableness lies. Determining the range of

140. According to Ayres' logic, see id. at 704-05, an equally acceptable solution to the problems posed by his basic standard would be to enjoin all lockups except those that are unmistakably nonforeclosing. Given his concession that there is a significant class of unfaithful "give aways" that courts cannot recognize as such, $i d$. at 703-04, Ayres might have argued that even if some stock lockups are not foreclosing, all lockups that are not unmistakably nonforeclosing should be enjoined because courts cannot distinguish those nonforeclosing lockups from foreclosing lockups. Such a standard would be radically overinclusive, but Ayres suggests no reason why the costs of such a standard would exceed the costs of his proposed standard. As a third alternative, Ayres might have recommended that all lockups be enforced, but that their size be reduced to an acceptable level whenever $V_{H}{ }^{2}<V_{R}$. This last approach would ensure competition for the target from an ex post perspective, while giving maximum effect to the contract and, hence, the potential ex ante justifications for the lockup. That Ayres did endorse this third alternative may suggest that he is not so confident, after all, that courts can accurately measure $V_{H}$. 
reasonableness is no easy task, however. ${ }^{141}$ In the average corporate takeover of the 1980's, after all, the acquiring firm paid a premium of fifty percent over market price for the target's stock. ${ }^{142}$ Given that many of those premiums were greater than fifty percent, and that a takeover premium provides only a lower benchmark for the acquirer's reservation price, ${ }^{143}$ it would seem difficult to argue that requisite valuations with implied premiums of one hundred percent or less would be beyond the range of reasonableness. It is thus unsurprising that Ayres offers no example of an actual case in which a court should have, according to his standard, enjoined a lockup. Indeed, applying his standard to the facts in Van Gorkom, ${ }^{144}$ a well-known case in which the Delaware Supreme Court held a target board liable for failing to take due care in its deliberations regarding the sale of the target (which included a lockup arrangement with the acquirer), Ayres finds that the lockup "seems to have been well within reason"145 and that even a lockup ten times that size-implying a requisite valuation of approximately $180 \%$ over the pre-bid price $^{146}$-might not have caused foreclosure. ${ }^{147}$

Perhaps there would be no dispute about a lockup arrangement implying a premium of more than, say, two hundred percent. ${ }^{148}$ But whatever the court-determined dividing point between mistakably and unmistakably foreclosing lockups might be, Ayres' modified proposal seems likely to be radically underinclusive, because courts would invalidate only those lockups for which the requisite valuation would "stretch the imagination to conceive" of a bidder valuing a target that much. ${ }^{149}$ To be sure, Ayres' standard would place a maximum on the size of lockups, but such a maximum would yield few, if any, benefits. Unfaithful target boards attempting to foreclose an auction in order to protect their jobs would grant as large a lockup (i.e., as much overinsurance) as is necessary to fully foreclose competitive bids, but no more. They would achieve their disloyal ends, in other words, by granting foreclosing lockups that were not, from the perspective of courts, unmistakably

141. Ayres offers no guidance on this question. See id.

142. Reinier Kraakman, Taking Discounts Seriously: The Implications of "Discounted" Share Prices as an Acquisition Motive, 88 ColUM. L. REv. 891, 892 (1988); Lynn A. Stout, Are Takeover Premiums Really Premiums? Market Price, Fair Value, and Corporate Law, 99 YALE L.J. 1235, 1235 n.1 (1990). The average takeover premium in 1968 to 1977 was $52.8 \%$ for takeovers not subject to state tender offer statutes, and $73.1 \%$ for takeovers subject to such statutes. Gregg A. Jarrel \& Michael Bradley, The Economic Effects of Federal and State Regulations of Cash Tender Offers, 23 J.L. \& ECoN. 371, 389-90 (1980).

143. Were this not the case, the acquirer would have no incentive to purchase the target.

144. Smith v. Van Gorkom, 488 A.2d 858 (Del. 1985). Jerome Van Gorkom was Trans Unions' Chief Executive Officer.

145. Ayres, supra note 9 , at 705 .

146. The pre-bid market price was $\$ 38$, see Van Gorkom, $488 \mathrm{~A} .2 \mathrm{~d}$ at 867 , and the requisite valuation with such a lockup would have been slightly more than $\$ 68$. Ayres, supra note 9 , at 706 .

147. Ayres, supra note 9, at 706.

148. But see infra text accompanying note 370 .

149. Ayres' modified standard would be even more difficult to apply to asset lockups, because there is no market price to use as a point of reference. See supra note 131. 
so. Once all rival bidders are foreclosed, the target board gains nothing, according to Ayres' reasoning, from selling more treasury stock (or selling it at a lower price) to the recipient bidder, because it has accomplished its goal of foreclosing all competitive bids. Likewise, the bidder gains nothing from having additional treasury stock, because there is no way for the bidder to benefit from the additional stock once potential third-party bidders are foreclosed. ${ }^{150}$ That is true because the option on treasury stock, recall, is of value to the bidder only if the bidder loses the auction. If all competing bids are foreclosed, however, then the bidder cannot lose the auction. ${ }^{151}$ For those reasons, neither the target nor the recipient bidder benefit in any significant way from increasing the lockup beyond what is necessary to foreclose other bidders. Ayres' modified standard, which would prevent only obviously excessive lockups, would serve only as a safe harbor for disloyal boards, who, under it, would be permitted to grant foreclosing lockups with impunity. ${ }^{152}$

\section{Can Foreclosing Lockups Be Loyal?}

Portions of the above discussion may be simplified by reference to the schema in Table 1.

150. Indeed, Ayres argues that a rational bidder would prefer to have a full-insurance, nonforeclosing lockup to a foreclosing lockup. See Ayres, supra note 9, at 703 \& n.55.

151. In other words, the more certainly a lockup forecloses competing bidders, the less value the lockup has to the preferted bidder, other things equal, because the less likely it will be that the preferred bidder will be able to tender its shares to a higher bidder. It might be argued that extremely excessive overinsurance creates added foreclosure benefits. But if that were the case, then it would suggest that the overinsurance was not excessive, inasmuch as it would imply that there are bidders with actual reservation prices above the lockup's requisite valuation. If there are bidders with reservation prices exceeding the requisite valuation, then it cannot be argued persuasively that the requisite valuation exceeds the range of reasonable reservation prices.

152. Of course, if courts enjoined lockups that were not obviously foreclosing, they would risk enjoining nonforeclosing lockups.

Having criticized Ayres' proposed standard for its radical underinclusiveness, we should note that our proposed standard would have the same substantive effect as his. The difference, as will become clear, is that we make the case for de jure enforcement of all lockups, while Ayres' standard provides only de facto enforcement of all lockups. Put differently, Ayres' standard, unlike our rule, is premised on the assumption that some lockups can be undesirable and, hence, should be invalidated. While his standard is thus fairly criticized as "underinclusive," ours is not. See also supra note 140 (explaining that Ayres' logic could as easily have lead to a standard that would have enjoined virtually all lockups). Still, although the motivations behind the alternatives are entirely different, the only significant practical advantage of our proposed rule over Ayres' is that ours would be less costly to administer. 


\section{TABLE 1. Measuring Lockups}

\begin{tabular}{|c|c|c|c|}
\hline & & \multicolumn{2}{|c|}{ Ex Ante } \\
\hline & & Compensatory & Supracompensatory \\
\hline \multirow{2}{*}{ Ex Post } & Nonforeclosing & (1) & (2) \\
\hline & Foreclosing & (3) & (4) \\
\hline
\end{tabular}

As already described, scholars who endorse the ex post approach-which would invalidate all foreclosing lockups-base their proposals on the explicit assumption, which they only partially defend, ${ }^{153}$ that foreclosure is a necessary condition for a lockup to be disloyal. A glance at Table 1, however, reveals that their proposals depend as well on the assumption that foreclosure is a sufficient condition. To be a sufficient condition, all foreclosing lockups must be also supracompensatory (i.e., disloyal). Put differently, Box 3 lockups must be a null set: An ex post approach that would prohibit foreclosing lockups would be unambiguously desirable only if all foreclosing lockups are also supracompensatory (Box 4). If, however, there can be ex ante justifications for foreclosing lockups, then courts adopting an ex post approach risk invalidating some loyal lockups, even assuming they can accurately identify foreclosing lockups. The question then becomes: Can foreclosing lockups be loyal?

Bainbridge and Ayres attempt to avoid the problem of Box 3 lockups by assuming that foreclosing lockups are also supracompensatory. For instance, Bainbridge implies as much where he asserts that a strong inference,

if not a presumption, of self-interest exists when a target board protects a Single Bidder merger agreement through a lock-up that effectively precludes competitive bidding. Why would an agent preclude the chance of a better competing bid for his principals if not for selfish reasons? The directors presumably must feel that a competing bidder could easily trump the deal they made and that, if trumped, they and management will not receive the side payments promised by the favored bidder. ${ }^{154}$

Similarly, Ayres assumes throughout much of his analysis that time in which to create an auction is the only consideration that a target board could

153. See infra Part III.B.2 (explaining how a nonforeclosing lockup might still be disloyal).

154. Bainbridge, supra note 1, at 323 (emphasis added); see also id. at 289 (an ex post approach is necessary in order to "neutralize the potential conflict of interest that may taint a decision to grant a [foreclosing] lock-up"); supra note 91 and accompanying text (treating the question of whether a lockup "is being used to protect side payments to management" and the question of whether a lockup "deters competing bids" as the same question). 
faithfully receive from a bidder in exchange for a lockup. ${ }^{155}$ According to Ayres, a bidder will agree to the delay where the "insurance," in the form of a lockup, adequately compensates the bidder for the fact that the bidder will, because of the delay, be more likely to lose in an auction. The quid pro quo is thus as follows: The target board buys time in which to create an auction, and the bidder buys insurance against the risk of losing in the auction that the target is thereby able to create. ${ }^{156}$ Viewing the lockup as a form of "auction insurance," 157 Ayres argues further that, insofar as the lockup makes the bidder prefer losing the auction to winning it-that is, insofar as the lockup is foreclosing-the lockup constitutes "overinsurance," by which he means that the lockup is supracompensatory. A "faithful target management, negotiating for additional auction time, would not need to guarantee a bidder more than its expected profits from winning a takeover." 158 There is a nice symmetry in Ayres' analysis between the ex post effects of a lockup and the ex ante justification. If the only purpose of the lockup is to provide "auction insurance," then, as Ayres seems to conclude, all compensatory lockups will be nonforeclosing (i.e., Box 1), and all foreclosing lockups will be supracompensatory (i.e., Box 4). ${ }^{159}$ Indeed, Ayres is at moments so confident

155. See, e.g., Ayres, supra note 9, at 696 ("A bidder will agree to hold a tender offer open only if the expected profits from a takeover auction with treasury shares exceeds the expected profits of proceeding with an abbreviated tender offer without treasury shares."); infra Part III.C.1.b.i (highlighting Ayres' view that lockups can be employed as a means of buying time in which to conduct an auction from the recipient bidder). If Ayres were correct that the only loyal ex ante goal of a lockup were to buy extra time, then courts might be able to eliminate many disloyal lockups simply by enjoining those lockups that were clearly not granted as a means of buying time. Indeed, if it were the case that boards had other means of creating delay that did not reduce bidders' reservation prices, see infra text accompanying 291-96, then one implication of Ayres' analysis would be that all lockups should be enjoined.

Other scholars have emphasized the importance of time for creating an auction. See, e.g., Bebchuk, supra note 9, at 24 ("A target's dispersed shareholders, under pressure to tender, are unable to act in concert to provide the necessary delay. Regulations that prescribe a mandatory delay period are thus crucial for competing bids. Consequently, I endorse such regulations ...."); id. at 26 (asserting the law should "enable the dispersed shareholders of a takeover target to function as a sole owner would"); $i d$. at 48 (same); id. at 45 (calling for a delay period in which to respond to an offer because "[a] target's dispersed shareholders are under pressure to tender. If they could act in concert, they presumably would often agree among themselves to hold out for some limited period and explore the possibility of a competing offer. Since transactions costs make such an agreement impossible, regulations are needed to secure the time that is crucial for competing bids."). The current federal regulation prescribes a 15-business-day waiting period within which tendered shares can be withdrawn. 17 C.F.R. $\$ 240.14 d-7$ (a) (1993).

156. The Delaware Chancery Court has recognized that providing competing bidders with additional time can justify merger agreements with lockups. See, e.g., In re Fort Howard Corp. Shareholders Litig., No. Civ. A. 9991, 1988 WL 83147, at *4 (Del. Ch. Aug. 8, 1988); Roberts v. General Instrument Corp., No. Civ. A. No. 11639, 1990 WL 118356, at $* 6$ (Del. Ch. Aug. 13, 1990); Barkan v. Amsted Indus., Inc., 567 A.2d 1279, 1287 (Del. 1989). While the courts properly evaluated the merger agreements in their entirety, there is no suggestion in any of these cases that the acquired company traded a lockup for additional time. Moreover, in Van Gorkom, the substantial amount of time available for competing bidders to surface (approximately 100 days between the announcement of the transaction and its scheduled completion) was not a determinative factor in the Delaware Supreme Court's ruling.

157. Ayres, supra note 9 , at 690 .

158. Id. at 703 (emphasis added).

159. As he puts it, where a lockup is foreclosing, it is clear that "the target management has breached its fiduciary duties to its shareholders." Id. at 704. Elsewhere he writes: "[F]oreclosure is inconsistent with maximizing shareholder welfare." Id. at 684 . Ayres recognizes that nonforeclosing lockups can be 
that all foreclosing lockups are disloyal that he argues that the rule enjoining foreclosing lockups should be mandatory-that is, incapable of being "changed through corporate action." " 60 "[T]arget corporations [sh]ould not be allowed to execute corporate provisions which increase the ability of target management to make overinsuring 'lockup' treasury shares."161 That is true, according to Ayres, because "[r]ational shareholders would not want to foreclose higher-valuing bidders from an auction."162

While Bainbridge and Ayres base their proposals on the assumption that foreclosing lockups are supracompensatory, each, elsewhere in his analysis and as somewhat of an afterthought, acknowledges that foreclosing lockups may well be compensatory. For instance, Bainbridge explains that a foreclosing lockup "may prove beneficial" (and, hence, loyal) to target shareholders in cases in which "target managers [are] able to extract a higher price or better terms in return for the greater certainty offered by lockups." 163 Similarly, Ayres concedes the possibility that foreclosure "stems from a faithful management negotiating, inter alia, a higher initial bid," meaning "that a foreclosing [lockup] may be engineered by either faithful or unfaithful management." 164 Neither Bainbridge nor Ayres suggests reasons why such compensatory foreclosing lockups might be any less common than supracompensatory foreclosing lockups. ${ }^{165}$

Thus, even according to proponents of the ex post approach, prohibiting some or all foreclosing lockups means sometimes prohibiting lockups that are loyal (i.e., Box 3 lockups). Consequently, the ex post approach risks collapse under the weight of the same problem it was designed to avoid-that is, the inability of courts to distinguish compensatory from supracompensatory lockups. Partially aware of the problem of Box 3 lockups, both Bainbridge and Ayres attempt to rescue their proposals, but, as we argue below, neither fully succeeds.

Bainbridge, for instance, asserts that his approach would permit target boards "to grant lockups exceeding the ten percent threshold where

supracompensatory (Box 2):

A treasury sale will affect third-party bids both through an "auction-creation effect" and through a "diluting effect." The former increases the likelihood of third-party bids being made, but the latter lowers the maximum amount that third parties will bid. Even a nonforeclosing treasury sale will harm target shareholders if the diluting effect exceeds the effect of creating an auction.

Id. at 706. However, he does not believe that supracompensatory but nonforeclosing lockups pose any threat to target shareholders. See supra text accompanying note 20 .

160. Ayres, supra note 9 , at 709 .

161. Id.

162. Id. (emphasis added).

163. Bainbridge, supra note 1 , at 328 .

164. Ayres, supra note 9, at $708 \mathrm{n} .72$; see also id. at $700 \mathrm{n} .49$ ("[T]reasury sales that induce higher initial bids might benefit target shareholders and thus rebut allegations of fiduciary breach.").

165. For additional reasons why a loyal target board might grant even foreclosing lockups, see infra Part III.C.2. 
appropriate,"166 (i.e., where compensatory and, hence, loyal), so long as they complied with an objective set of prophylactic steps."167 That is, courts "would enforce large lockups where they were granted after a judicially approved auction that would "require the board to voluntarily shop the company among other bidders before agreeing to the lock-up."168 But Bainbridge overlooks the fact that, by requiring the target board to "conduct a voluntary control auction,"169 his proposal would substantially eliminate the target managers' ability to use a lockup to extract a higher bid. After all, the recipient.bidder would have already won the auction for the target and would therefore face little or no threat of losing the target to a higher bidding competitor. Because the recipient bidder will have thus demonstrated that it is the highest valuing bidder, the target board promising a lockup would have little or nothing to bargain with. ${ }^{170}$

Ayres' defense is similarly flawed. After admitting the Box 3 problem created by his ex post approach, he attempts to rescue the approach by proposing that once courts have established that a lockup is foreclosing, they should at least

shift the burden to the target to justify the size of the treasury sale in relation to any enhanced negotiated initial bid and anticipated higher bids. The target management could then rebut a presumption of fiduciary breach by showing either [1] that the treasury sale was conditioned upon a higher initial bid, or [2] that they were not grossly negligent in believing that the treasury sale was not foreclosing. ${ }^{171}$

But it is not at all clear how a board could meet either requirement. The first is substantially identical to Delaware's current ex ante approach, and, were such an approach sensible, there would be no need for an ex post approach in the first place. ${ }^{172}$ Moreover, it would be extremely difficult for a target board to show that it was not grossly negligent in believing that a lockup was not foreclosing after the court has determined that the lockup is unmistakably foreclosing-that is, where it would "stretch the imagination" to assume that the lockup was not foreclosing. ${ }^{173}$

166. Bainbridge, supra note 1 , at 323 .

167. Id.

168. Id. at $327-28$.

169. Id. at 328 .

170. See infra Parts III.C.2-3 (describing numerous ex ante justifications for lockups, almost all of which depend on a lockup being granted prior to an auction). Of course, if a lockup remains of significant value to the recipient bidder, that simply implies that the target board did a poor job of auctioning the target.

171. Ayres, supra note 9 , at 708 n.72.

172. See supra Part II.B (describing problems with ex ante approach, including the incentive it creates for target boards and recipient bidders to enter into sham negotiations).

173. See supra text accompanying notes $135-49$. 
In sum, while Bainbridge and Ayres both reluctantly acknowledge the problem with foreclosing, compensatory (i.e., Box 3) lockups, neither is able to overcome the difficulty facing the ex ante approach-that is, distinguishing compensatory from supracompensatory lockups. In our view, the problem of Box 3 lockups is insuperable. Recall that the higher the bid made in exchange for a lockup, the more likely the lockup is to be foreclosing, other things equal. ${ }^{174}$ But as Bainbridge and Ayres both concede, a foreclosing lockup may be compensatory where it is given in exchange for a higher bid. Thus the same variable-the size of the recipient bidder's bid-that makes the lockup foreclosing may concomitantly make the lockup compensatory. Ironically, then, the more successful the target board is at extracting a high bid, the more likely courts are, under an ex post approach, to invalidate the lockup. Or, conversely, the more successful a target board is at foreclosing third-party bidders, the more likely courts are, under an ex ante approach, to enforce the lockup.

\section{A NEW VIEW OF LOCKUPS}

\section{A. Can Lockups Be Foreclosing?}

We have argued thus far that both the ex ante and ex post perspectives can be relevant in assessing the loyalty of lockups, for the only lockups that are of concern are those that are both supracompensatory and fully foreclosing (i.e., Box 4 lockups $^{175}$ ). Lockups that are not supracompensatory are, by definition, in the interest of target shareholders even if they might foreclose other bidders. And lockups that are not fully foreclosing do not threaten target shareholders even if supracompensatory. When a court can say with confidence that a lockup is either nonforeclosing or compensatory (Boxes 1,2 , and 3 ), the court should enforce the lockup. ${ }^{176}$ But there will often be uncertainty about whether the lockup is both supracompensatory and fully foreclosing (Box 4). And, as we have argued, no rule or standard has been, or is likely to be, devised that would assist courts in identifying such lockups. More specifically, neither Delaware's ex ante approach, nor scholars' proposed ex post approaches are of practical use in helping courts to distinguish either compensatory from supracompensatory lockups along the ex ante dimension

174. See supra text accompanying notes $116-26$.

175. See supra Table 1.

176. For example, where a recipient bidder raises its bid after receiving a lockup (implying that the recipient would profit more by winning than by losing the target after the lockup), the lockup is probably nonforeclosing. See, e.g., Samjens Partners I v. Burlington Indus., Inc., 663 F. Supp. 614, 625 (S.D.N.Y. 1987); Paramount Communications, Inc. v. QVC Network, Inc., 1994 WL 30181 (Del. Feb. 4, 1994). Moreover, where the exercise price of the lockup option, $P$, equals or exceeds the recipient bidder's bid, $B_{i}^{\prime}$ (as is true in many cases), the lockup must be nonforeclosing. See QVC Network Inc. v. Paramount Communications Inc., 635 A.2d 1245 (Del. Ch. 1993). Scholars and courts have not previously recognized, however, that such lockups cannot be foreclosing. 
or nonforeclosing from foreclosing lockups along the ex post dimension. Thus, the question that remains is whether courts should enforce or enjoin lockups that fall within this range of ambiguity along both dimensions.

While we argued above that the problem of distinguishing lockups that benefit target shareholders from those that do not seems insuperable, we argue below that the problem may be illusory. Lockups, no matter their terms, pose little or no threat to the goal of allocative efficiency or to the interest of target shareholders. Even Box 4 lockups pose no threat to target shareholders because, as the following two sections argue, target boards are unwilling and unable to foreclose higher valuing bidders.

\section{A Target Board's Unwillingness To Foreclose Higher Valuing Bidders}

Those critical of lockups seem not to have recognized that a disloyal board, just as a loyal board, has an incentive to sell to the highest valuing bidder. In most contexts, both sides of a contract will benefit whenever the total gains created by the contract are increased. ${ }^{177}$ The same seems likely to be true in the takeover context. To take a very simple example, suppose that target shareholders would be willing to sell their firm for some amount greater than $\$ 75$. Suppose also that Bidder 1 values the target firm at $\$ 100$ while Bidder 3 values it at $\$ 150$. Obviously, a loyal board would seek to sell to Bidder 3 at some price between $\$ 100$ and $\$ 150$ in order to extract for shareholders some portion of the additional $\$ 50$ in total gains to trade. By the same token, a disloyal board would seek to sell to Bidder 3 in order to extract for itself some of those gains. Or look at it another way. Takeover bids can be understood to have two facets: first, the public facet, containing a per-share stock price offered to all target shareholders and, second, the nonpublic facet, containing side payments offered to the target's management. Because a higher valuing bidder could always match the public facet and still beat the nonpublic facet of a lower valuing bidder's bid, disloyal boards will want to sell to the highest valuing bidder. ${ }^{178}$ In short, that target boards may sometimes act on their own behalf instead of on shareholders' behalf does not alter their incentive to sell to the highest valuing bidder. ${ }^{179}$

177. See, e.g., POSNER, supra note 53, at 82 (explaining that "the larger the joint profit is, the larger the 'take' of each party is likely to be"); Steven Shavell, The Design of Contracts and Remedies for Breach, 99 Q.J. ECON. 121 (1984) (freely negotiated contracts will maximize total gains to contracting).

178. Suppose that Bidder 1 values the target at some amount, $V_{1}$, that the market price of the target prior to any takeover bid equals some amount, $M\left(<V_{1}\right)$, and that the target's shareholders would willingly sell to Bidder 1 for $M+e(<V)$ (where $e$ is pasitive but trivially small). Suppose further that if the target's board resists the takeover, it can extract $V$, from Bidder 1 , and that the target's board will resist if the incumbent management does not view the transaction favorably. In that case, Bidder 1 would be willing to pay the incumbent management $V_{1}-(M+e)$ not to resist. Thus, Bidder I's willingness to pay side payments will increase in $V_{l}$, and hence, the target's board will seek to sell to the highest valuing bidder.

179. Consider the Delaware Chancery Court's reasoning to the contrary in MacAndrews \& Forbes Holdings v. Revlon, 501 A.2d 1239 (Del. Ch. 1985). According to the court, the Revlon board members 
Moreover, the entire comparison between "faithful" and "unfaithful" boards is based on a premise-either exaggerated or false-that a target board will improperly allow side payments from a bidder to sway its actions. From this notion springs the Revlon presumption that anything short of complete neutrality between bidders constitutes a breach of the board's fiduciary duty to the shareholders, regardless of whether any actual evidence of improper influence exists. One factor suggesting that the premise is at least partially counterfactual is that federal securities laws require companies involved in the acquisition of a public company to disclose a great deal of information, ${ }^{180}$ including descriptions of any contracts, arrangements, understandings, relationships, or the like that a security holder might find material. ${ }^{18 t}$ Failure to disclose the requested material under any of these forms is a violation of law. Thus, implicit in the Revlon decision and its progeny is the assumption not only that side payments exist, but also that bidders and directors (or perhaps their legal counsel), in the face of a panoply of possible sanctions, conspire to keep these payments secret. ${ }^{182}$ As there is little reason to believe

breached their duty of loyalty by making concessions to Forstmann, because they were more concemed about liability to the noteholders than about maximizing the sale price of the company for the stockholders' benefit. Id. at 1249-50. This argument misses the point. If Revlon's board truly were seeking to protect itself from liability, which is doubtful, see supra note 53 , the board could have obtained from a higher valuing bidder the same indemnity it received from Forstmann. Lockups will not be offered to protect arrangements that any higher valuing bidder would match. This point is analogous to the argument made in the products liability literature that manufacturers with monopoly power will not exercise that power by reducing the quality of their products. They will provide optimal levels of quality because doing so permits them to maximize their profits. See Alan Schwartz \& Louis L. Wilde, Imperfect Information in Markets for Contract Terms: The Examples of Warranties and Security Interests, 69 VA. L. REv. 1387, 1402-20 (1983); Steven P. Croley \& Jon D. Hanson, Rescuing the Revolution: The Revised Case for Enterprise Liability, 91 MICH. L. REV. 683, 717-19 (1993).

180. The bidder must complete a Tender Offer Statement (Schedule 14D-1); the subject company, a Solicitation/Recommendation Statement (Schedule 14D-9), as well as perhaps an Issuer Tender Offer Statement (Schedule 13E-4) or a Proxy Statement (Schedule 14A). For a summary of some of the legal issues surrounding lockup agreements, see Fraidin \& Franco, supra note 23, at 825-27.

181. Such disclosure is in fact fairly routine. For example, during the course of Forstmann Little's 1986 acquisition of Lear Siegler, Forstmann sent a letter to the President of Lear Siegler promising him, among other things, that after the takeover he would not be removed from office. When Forstmann filed its Schedule 14D-1 with the SEC, it included a copy of the letter as one of its attached exhibits, as did Lear Siegler in its 14D-9 and 13E-4 filings.

182. Disclosure violations under Rules $14 \mathrm{~d}-9$ and $14 \mathrm{~d}-1$ may become the source of a criminal indictment, private civil litigation, or an SEC administrative action.

Section 32(a) of the Exchange Act, 15 U.S.C. $\$ 78 \mathrm{ff}$ (1988), authorizes criminal proceedings for violations of the Exchange Act and its rules. The provision specifically provides for criminal sanctions against a defendant "who wilfully and knowingly makes, or causes to be made, any statement in any application, report, or document required to be filed under [the Exchange Act] or any rule on regulation thereunder ... which statement was false or misleading with respect to any material fact . . . ." Id.

As a practical matter, violations of Rules $14 \mathrm{~d}-1$ and $14 \mathrm{~d}-9$ are most likely to serve as a predicate for a criminal action under Section 32(a) or a more general U.S. Code provision proscribing false statements "in any matter within the jurisdiction of any department or agency of the United States." 18 U.S.C. \$ 1001 (1988). See, e.g., United States v. Bilzerian, 926 F.2d 1285 (2d. Cir. 1991), cert. denied, 112 S. Ct. 63 (1991).

Although Section 14(d) of the Exchange Act does not craft an explicit private right of action, courts have recognized an implied right of action for violations of this provision. For example, in Florida Commercial Banks v. Culverhouse, 772 F.2d 1513 (11th Cir. 1985), the Eleventh Circuit held that a target corporation had a private right of action, under Sections 14(d) and 14(e) of the Exchange Act, to seek 
that is actually the case, the courts might do best to limit their involvement in takeover battles to those relatively few instances in which an actual breach of the duty of loyalty is at issue, as opposed to merely assuming that such a breach has taken place in secrecy. ${ }^{183}$

Thus, whether their motives are loyal or disloyal, target boards have an incentive to avoid foreclosing higher valuing bidders. To the extent that target managements are pursuing disloyal side payments, they will want to sell to the highest valuing bidder in order to maximize those side payments. To the extent that they are dissuaded from pursuing disloyal side payments by the threat of civil or criminal sanctions, they will want to sell to the highest valuing bidder in order to maximize shareholder revenues.

corrective disclosures from a tender offeror who allegedly filed a false and misleading Schedule 14D-1 with the SEC; see also Koppers Co., Inc. v. American Express Co., 689 F. Supp. 1371, 1384 (W.D. Pa. 1988) ("Under the Williams Act, a target corporation has a private cause of action to obtain corrective disclosures from a tender offeror who has disseminated allegedly false and misleading tender offer materials."); American Carriers, Inc. v. Baytree Investors, Inc., 685 F. Supp. 800, 808 (D. Kan. 1988) (recognition of the plaintiff's standing to bring an injunctive action against the tender offeror under Sections 14(d) and 14(e) of the Exchange Act "is necessary ... . in order to give effect to the Williams Act").

The Securities Enforcement Remedies and Penny Stock Reform Act of 1990, Pub. L. No. 101-429, 104 Stat. 931 (1990) ("Remedies Act"), broadened the remedies available to the SEC to address violations of the tender offer rules. At the time the Remedies Act was adopted, the sanctions available to the Commission included: (1) issuing cautionary letters, which were minimal, nonpublic sanctions; (2) issuing stop orders, which suspended the effectiveness of a registration statement; (3) referring the matter to an SRO or state regulatory authority; (4) issuing an investigative report under section 21(a) of the Exchange Act; (5) bringing administrative proceedings under section 15(c)(4) of the Exchange Act; or (6) seeking injunctive relief in federal district court. See Ralph C. Ferrara \& David Nerkle, Overview of an SEC Enforcement Action, 8 CORP. L. REV. 306, 322-24 (1985).

The Remedies Act authorized the SEC to: (1) seek monetary penalties of up to $\$ 100,000$ against any person, or up to $\$ 500,000$ against any entity for violations of the federal securities laws and regulations other than insider trading, and for violations of cease and desist orders, Pub. L. 101-429, 104 Stat. 931, 937 (codified at 15 U.S.C. $\$ 78 \mathrm{u}-2$ ); and (2) issue cease and desist orders against any person or entity which are, in effect, administrative injunctions, to order a person to comply, or to take steps to effect compliance, with such provision, rule, or regulation, upon such terms and conditions and within such time as the SEC may specify and to order a respondent to account for and disgorge profits, Pub. L. 101-429, 104 Stat. 931, 939 (codified at 15 U.S.C. § 78u-3).

In at least four cases, the SEC has employed its new authority under the Remedies Act to issue permanent cease and desist orders for violations of the tender offer rules. See In re The Lionel Corporation, Exchange Act Release No. 30,121, 50 SEC Docket (CCH) 732 (Dec. 30, 1991) (finding violations of section 14(d)(4) and Rule 14d-9, SEC issued permanent cease and desist order against the Lionel Corp. from violation of Section 14(d)(4) and Rule 14d-9 thereunder); In re RIT Acquisition Corp. \& Robert I. Toussie Ltd Partnership, Exchange Act Release No. 30,732, 51 SEC Docket (CCH) 828 (May 22, 1992) (finding violations of section 14(d) and Rules 14d-3 and 14d-6 thereunder, SEC issued permanent cease and desist order against the RIT Acquisition Corp. and others); In re Kelso \& Co., Inc., Exchange Act Release No. 31,639, 53 SEC Docket (CCH) 177 (Dec. 23, 1992) (finding violations of Section 14(d) and Rule 14d-6 thereunder, SEC issued permanent cease and desist order against Kelso \& Co., Inc.); In re William A. Wilson, Exchange Act Release No. 32,392, 54 SEC Docket (CCH) 489 (June 1, 1993) (finding violations of section 14(d) and Rule 14d-9 thereunder, SEC issued permanent cease and desist order against Wilson). 1993).

183. See, e.g., Cede \& Co. v. Technicolor, Nos. 336 \& 337, 1993 Del. LEXIS 398 (Del. Oct. 22, 


\section{A Target Board's Inability To Foreclose Higher Valuing Bidders}

A target board seeking to entrench its current management will try to sell to the highest valuing bidder for a second reason: Any attempt to strike a deal with a lower valuing bidder will be in vain. To see why, consider the fully foreclosing lockup depicted in Figure 5.

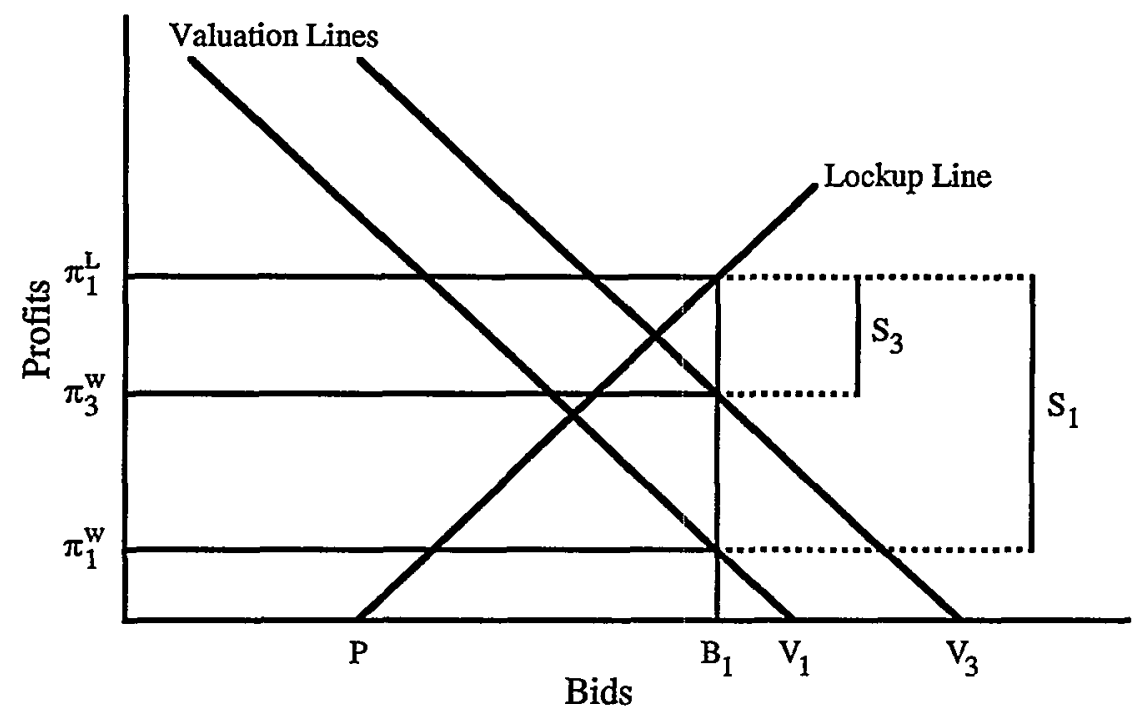

FIGURE 5. The Gains to Contracting Around "Foreclosing" Lockups

Bidder 1's bid of $B_{1}$ forecloses Bidder 3 from bidding because Bidder 3 would lose " $S_{3}$ " were it to match Bidder 1's bid (i.e., $\pi_{t}{ }^{2}-\pi_{3}{ }^{w}=S_{3}>0$ ). That is, Bidder 3 would gain $\pi_{3}{ }^{W}$ but would have to pay Bidder $1 \pi_{t}^{L}$ because of the lockup. Thus, to save $S_{3}$, Bidder 3 will not compete with Bidder 1 . Bidder 1 , however, very much wants Bidder 3 to compete, for Bidder 1 will enjoy higher profits if it loses the auction, $\pi_{l}{ }^{2}$, than if it wins, $\pi_{l}{ }^{w}{ }^{184}$ The difference between the two, $S_{l}$ (i.e., $\pi_{1}{ }^{2}-\pi_{l}{ }^{w}=S_{1}>0$ ), measures the gains to Bidder.1 of finding a higher valuing bidder. As illustrated in Figure 5, there are clearly gains to trade here: Bidder 1 is willing to pay Bidder 3 some amount, $S$, such that $S_{1}>S>S_{3}$; and Bidder 3 would be willing to take the target over with the lockup if it were paid $S .{ }^{185}$

184. See supra text accompanying notes 111-12. Cf. Ayres, supra note 9, at 700 ("Extreme forms of treasury sales cause the bidder purchasing treasury shares to root for rivals to outbid its initial offer.").

185. To see the point algebraically, recall that with a foreclosing lockup, Bidder l's profit from losing would be greater than its profits from winning at the given bid:

(10) $\left(B_{1}-P\right) T>\left(V_{1}-B_{1}\right) N$. 
This portion of our analysis of lockups replicates the basic lesson of the Coase Theorem, which holds that so long as contracting costs are not prohibitive, parties will contract to the same allocation of resources no matter the legal rule and no matter their initial allocation. ${ }^{186}$ Put differently, so long as those contracting costs, $C$, are lower than the gains to contracting, $G$ (i.e., $\left.G=S_{1}-S_{3}\right),{ }^{187}$ courts should enforce even "fully foreclosing" lockups, because even such a lockup will in fact be "nonforeclosing" or nonpreclusive. The question for policymakers thus becomes whether, in fact, $G>C$.

There are, generally speaking, two contexts within which a higher valuing nonrecipient bidder, Bidder 3, otherwise foreclosed by a lockup from purchasing the target directly from target shareholders, might contract with the recipient bidder, Bidder 1: (1) after Bidder 1 has successfully acquired the Target in a "resale" or (2) prior to the completion of Bidder 1's takeover of the Target in a "pre-sale."

Consequently, Bidder 1 would be willing to pay up to some positive amount, $S_{l}$, to Bidder 3 for Bidder

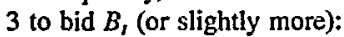

(11) $S_{t}=\left(B_{1}-P\right) T-\left(V_{1}-B_{1}\right) N$.

Absent any payment from Bidder 1, Bidder 3's net loss from winning at the given bid would be:

(12) $\left(B_{1}-P\right) T-\left(V_{3}-B_{1}\right) N$.

Thus, Bidder 3 would be willing to offer $B_{t}$ for the target whenever Bidder 1 paid Bidder 3 at least $S_{3}$ :

(13) $S_{3}=\left(B_{1}-P\right) T-\left(V_{3}-B_{1}\right) N$.

Gains to trade exist between Bidder 1 and Bidder 3 whenever

(14) $S_{1}-S_{3}>0$.

That will be true whenever a lockup forecloses a higher valuing bidder:

(15) $S_{1}-S_{3}=\left[\left(B_{1}-P\right) T-\left(V_{1}-B_{1}\right) N\right]-\left[\left(B_{1}-P\right) T-\left(V_{3}-B_{3}\right) N\right]$.

Equation (15) simplifies easily to the following:

(16) $S_{t}-S_{3}=\left(V_{3}-V_{1}\right) N$.

Because, by hypothesis, $\left(V_{3}-V_{1}\right) N>0$, there will always be gains to trade when a lockup is foreclosing a higher valuing bidder.

A numerical example may help make this clear. Suppose that Bidder 1 values Target, which has a pre-bid market price of $\$ 75$ per share, at $\$ 125$ per share. Suppose further that Bidder 3 , the highest valuing bidder, values Target at $\$ 150$ per share. Suppose finally that Bidder 1 makes a bid of $\$ 115$ per share in exchange for a lockup. Now, if the lockup is worth $\$ 10$ or less per share, it will not foreclose any higher valuing bidders, including Bidder 3 . Under such circumstances, Bidder 3 will win Target with a bid of $\$ 116$ and the $\$ 75$ of gain will be allocated as follows: Bidder 1 will receive the value of the lockup, $\$ 10$; Bidder 3 will pay the shareholders $\$ 116$ per share and Bidder $1 \$ 10$ per share, leaving $\$ 24$ worth of buyer's surplus; and shareholders will receive from Bidder 3 a $\$ 41$ premium per share.

If instead the lockup is worth $\$ 35$ (or more) it will foreclose all other bidders, including Bidder 3 . Under those circumstances, Bidder 3 will still end up owning Target, but the $\$ 75$ of gain will be allocated differently. Bidder 1 will pay Bidder 3 up to $\$ 25$ per share $\left(S_{1}\right)$ to make a bid of $\$ 116$ per share. Bidder 3 requires $\$ 1$ per share $\left(S_{3}\right)$ to make a bid. Assuming Bidder 1 and Bidder 3 split the gains to trade evenly, the $\$ 75$ gain will be allocated as follows: Bidder 1 will receive $\$ 35$ from the lockup but will pay $\$ 12.50$ per share to Bidder 3 for a net gain of $\$ 22.50$; Bidder 3 will pay $\$ 116$ per share to shareholders, and $\$ 35$ per share to Bidder 1, but will receive $\$ 12.50$ per share from Bidder 1, leaving $\$ 11.50$ worth of buyer's surplus; and shareholders will receive from Bidder 3 a $\$ 41$ premium per share. Although the size of the lockup may affect how the $\$ 75$ gain is split between the two bidders, it does not affect who wins the target (in both cases the highest valuing bidder wins) or the premium gains to target shareholders (in both cases there is a premium of $\$ 41$ per share).

If the lockup is worth between $\$ 10$ and $\$ 35$ per share, it will be partially but not fully foreclosing. Bidder 3 will outbid Bidder 1 (with or without some payment from Bidder 1).

186. See generally Ronald H. Coase, The Problem of Social Cost, 3 J.L. \& ECON. 1 (1960).

187. Applying basic principles of geometry, one can readily prove that $G=V_{3}-V_{l}$. 


\section{a. The Transactions Costs of Resales}

Although corporate law scholars have debated the transactions costs of resales, no clear consensus has emerged. Constituting only a portion of a larger, now classic exchange regarding the desirability of corporate control auctions, ${ }^{188}$ the debate was really about whether one or more independent sales without an auction would be a more or less costly means of transferring corporate assets to their highest valued use than would a single auction. ${ }^{189}$ Participants in that exchange offered various comparative analyses of two general types of transactions costs: (1) the information and contracting costs necessary to identify the takeover opportunity and to execute the transaction (assuming no agency costs) and (2) the agency costs resulting from the desire of the acquiring firm's board to maintain or increase the size of its enterprise and its ability to forestall or prevent sale of the target to a higher valuing bidder. ${ }^{190}$

With respect to information costs, Ronald Gilson reasons that a series of independent sales may create a greater amount of transactions-costs friction

simply because the wheel must be reinvented each time. In fact, the cost of reinvention may actually rise: While public information about the business is readily available from regulatory filings and shareholder reports at the time of the initial transfer, by the time of a succeeding transfer this information may be buried in a mass of less useful data covering the combined company. ${ }^{191}$

In response, Easterbrook and Fischel point out that the information and contracting costs associated with resale may be unavoidable. An auction does not change the fact that many of a target's assets are likely to be retransferred to different firms after the first transfer to the auction winner. ${ }^{192}$ Bebchuk notes, however, that even if assets are ultimately transferred to their highest

188. See generally Symposium, 35 STAN. L. REV. 1 (1982) (symposium on corporate control auctions).

189. See, e.g., Easterbrook \& Fischel, supra note 9, at 14.

190. See, e.g., EASTERBROOK \& FISCHEL, supra note 5, at 14; Lucian A. Bebchuk, The Case for Facilitating Competing Tender Offers, 95 HARV. L. REV. 1028, 1048-49 \& n.81 (1982); Bebchuk, supra note 9, at 39-40; Gilson, supra note 1, at 870-72; Ronald J. Gilson, Seeking Competitive Bids Versus Pure Passivity in Tender Offer Defense, 35 STAN. L. REV. 51, 62-64 (1982) [hereinafter Gilson, Seeking Competitive Bids]; Schwartz, supra note 10, at 242-44; see also Ralph K. Winter, Jr., State Law, Shareholder Protection, and the Theory of the Corporation, 6 J. LEGAL STUD. 251, 269 (1977) ("The most important of these [transactions costs of takeovers] is that of acquiring information about firms which are likely prospects for substantial capital gains if given more efficient management."). Scholars sometimes mention "mechanical costs," such as "lawyers', accountants", and investment bankers' fees necessary to effect the transaction," as a third category of cost but offer few if any arguments to suggest that those costs are any greater under one approach or another. See, e.g., Gilson, Seeking Competitive Bids, supra, at 62-63.

191. Gilson, Seeking Competitive Bids, supra note 190, at 63.

192. Easterbrook \& Fischel, supra note 9, at 14; see also SANJAY BHAGat ET AL., Hostile TAKEOVERS IN THE 1980S: THE RETURNS TO CORPORATE SPECIALIZATION 35 (1990) (finding that of 62 acquisitions, sell-offs occurred in 42 cases; "selling off divisions is one of the most pervasive consequences of hostile takeover"). 
valued use via one or more resales, such re-transfers "might involve a significant delay," which, presumably, a single auction would not. ${ }^{193}$

Agency costs, according to both Bebchuk and Gilson, may pose an even greater impediment to an efficient resale market: "[T]he acquirer's managers may decide to retain the target's assets to avoid reducing the size of the enterprise under their control."194 And, if as a consequence of that disloyal maximand, "management ... resists the second sale in a series, the offer will not only be a hostile one, it will be a larger transaction than the original because the second round covers the combined corporation." 195 Such an expansion in the size of the target may reduce the number of potential bidders and thus the likelihood that the original set of corporate assets end up in their highest valued use. ${ }^{196}$ In response to that line of reasoning, Easterbrook and Fischel point out that "[f]irms routinely sell parts of their operations to other firms" and that "[t]here is ... little evidence to support the belief that managers systematically reject the opportunity to profit by selling plants and divisions." ${ }^{197}$ Bebchuk and Gilson each respond, however, that "[w]hile there may be no hard evidence, there is good theory," to support the view that an acquirer will resist resale in order to maximize the size of its enterprise. ${ }^{198}$ According to that theory, managers are often more interested in building an empire then they are in maximizing shareholder returns. On the assumption that there is such an agency cost, Easterbrook and Fischel have argued that an auction rule would simply provide a tool for disloyal agents. As they explain, "it is all too easy for [target] managers to conduct a defensive strategy under the guise of running an auction." 199 Bebchuk denies the significance of Easterbrook and Fischel's claim by pointing out that any potent obstructive tactic, including lockups, "can hardly be disguised."200 More recently, Alan Schwartz has argued that there is no such agency cost, showing that "even were some or all firms to prefer size to profits, an unregulated market [i.e., one that relied on resales rather than auctions] would produce the same configuration of ownership as auctions would."201 To state his conclusion succinctly, whatever the motive may be underlying each bidder's valuation of the target, the bidder with the highest valuation will end up with the target;

193. Bebchuk, supra note 10, at 266. Although Bebchuk may be correct, it bears noting that Bebchuk's primary goal in proposing an auction rule is to create delay between the time when a takeover is initiated and when it is completed. See infra note 231 and accompanying text.

194. Bebchuk, supra note 9, at 41 (emphasis added); see Gilson, Seeking Competitive Bids, supra note 190 , at 63.

195. Gilson, Seeking Competitive Bids, supra note 190, at 64; Bebchuk, supra note 9, at 28.

196. Gilson, Seeking Competitive Bids, supra note 190, at 64.

197. Easterbrook \& Fischel, supra note 9, at 14-15.

198. Gilson, Seeking Competitive Bids, supra note 190, at 63; see Bebchuk, supra note 9, at 37, 42.

199. Easterbrook \& Fischel, supra note 9, at 15; see also Schwartz, supra note 10, at 244 ("[T]arget managers ... have the incentive to cause the auction to fail altogether . ...").

200. Bebchuk, supra note 9, at 47.

201. Schwartz, supra note 10 , at 243. 
whether the target is transferred via an auction or resale, "firms that want targets the most will own them."202

While Schwartz's argument seems to dispose of the putative agency-cost impediment to resales, the debate over the relative size of transactions costs of the auction and resale methods of transferring corporate assets was not and, as its participants acknowledge, cannot be fully settled at the level of theory. ${ }^{203}$ According to Gilson, however, the fact that second bidders in the current regime often choose the auction method rather than the resale method is itself "powerful empirical evidence" that a resale rule has higher transactions costs than an auction rule. ${ }^{204}$ Although defenders of the resale method have not responded to that claim, there appears to be a flaw in Gilson's logic. That is, because the current regime is an auction regime, a potential bidder cannot necessarily avoid the costs of participating in an auction merely by waiting to acquire the target from the first bidder. Such a strategy would simply lead to an auction at the next stage. Thus, while it may be true that a bidder wishing to acquire a target is likely to find that the cheapest strategy under the current auction rule is to join the auction contest, that "evidence" does not support Gilson's conclusion that the auction method is more efficient in terms of transactions costs than the resale method. It simply begs the question.

In sum, the question of whether a resale rule would have higher or lower transactions costs than an auction rule remains unanswered. Nevertheless, legal scholars analyzing the desirability of lockups have assumed, usually by implication, that the transactions costs of resale exceed the potential gains to trade that exist between a recipient bidder and a higher valuing third-party bidder (i.e., $C>G$ ). Indeed, Ian Ayres makes that assumption quite explicit, remarking that " $[\mathrm{b}]$ oth empirical and theoretical reasons exist . . . for expecting that the transactions costs of resale will not eliminate all gains from treasury share trade" and citing Gilson's arguments that we highlighted above. ${ }^{205}$ Similarly, Stephen Bainbridge concedes the theoretical possibility that "a competing bidder shut out of an initial acquisition by [a] . . . lockup could acquire the combined entity . . . [and thereby] constrain the target board's selfinterested behavior in the initial acquisition," but concludes, in effect, that the transactions costs are so high that the likelihood of such a resale is, in practice, "de minimis." ${ }^{206}$ In this way, Ayres and Bainbridge assume the Coase Theorem out of their analysis. For a variety of reasons, however, such an

202. Id. at 244. In light of Schwartz's argument, Bebchuk has recanted his agency-cost argument. See Bebchuk, supra note 10 , at 266 n.8.

203. Bebchuk, supra note 10, at 269-70; Easterbrook \& Fischel, supra note 9, at 14; Gilson, Seeking Competitive Bids, supra note 190, at 62 (resolution turns on analysis of transactions costs, but analysis would require a "good deal more effort").

204. Gilson, Seeking Competitive Bids, supra note 190, at 62 (emphasis added).

205. Ayres, supra note 9, at 697 n.42.

206. Bainbridge, supra note 1 , at 280 . 
assumption does not resolve the question as to whether "fully foreclosing" lockups are in fact foreclosing.

First, as we just summarized, the transactions-costs debate, taken as a whole, yields no dispositive answer. Indeed, in our estimation, proponents of the low-transactions-costs view got the better of their opponents in the auction debate. Scholars analyzing the foreclosing effects of lockups could at least as plausibly have assumed that the transactions costs of resale are trivial and concluded, as we will, that lockups of any size are harmless.

Second, the transactions-costs debate (within the larger auction debate) is largely inapposite to the question of whether lockups are foreclosing. To understand why that is true, it is necessary to understand that there are often two concerns with respect to transactions costs: (1) are transactions costs high in absolute terms; or (2) are they transaction prohibitive? ${ }^{207}$ There is, of course, some correspondence between the size and effect of transactions costs: the higher (lower) they are, the more (less) likely they are to exceed the potential gains to contracting. Nevertheless, transactions costs can be significant but still not transaction-prohibitive. The transactions-costs debate that corporate law scholars held in the 1980's was over the relative size of transactions costs. That is, they endeavored to determine whether the transactions costs of a resale rule (" $C_{R}$ ") exceed those of an auction rule (" $C_{A}$ "). But in assessing the potential threat of lockups, we are concerned only with whether the transactions costs of resale exceed the gains to trade between the actual acquirer and the would-be acquirer (i.e., is $C_{R}>G$ ). A series of resales could be more costly than a single auction, but still not be transactionprohibitive. Yet, only when transactions costs are prohibitively high might a "fully foreclosing" lockup pose any real threat to allocational efficiency. ${ }^{208}$

Finally, and perhaps most important, the entire 1980's debate over the relative size of transactions costs considered only those of resale. As noted above, however, there exists a second context in which trade can occur between the recipient bidder and the higher valuing third-party bidder-that is, before the target is sold to the recipient bidder. Thus, even were it shown that resale costs were relevant, it is entirely possible that "pre-sale" costs (" $C_{p}$ ") are not. Indeed, considered speculation strongly suggests that $C_{P}$ will be extremely low in most cases and, hence, less than $G$ (except, perhaps, where $G$ is trivial

207. Cf. Croley \& Hanson, supra note 179 , at 729 (making a similar distinction); Robert $M$. Daines \& Jon D. Hanson, The Corporate Law Paradox: The Case for Restructuring Corporate Law, 102 YALE L.J. 577, 582 n.20 (1992) (making a similar distinction in review of EASTERBROOK \& FISCHEL, supra note $5)$.

208. This is not to suggest that policymakers should never be concerned about the size of transactions costs. Our claim, and the implicit claim of exponents of an ex post approach, is simply that if transactions costs are not transaction-prohibitive, then the fact that those costs may be significant does not provide courts a reason to intervene. Because target boards will understand that their jobs cannot be protected via lockup arrangements, they will have little incentive to employ lockups in a disloyal way. Moreover, if it can be assumed that target boards were acting loyally, there is no reason to doubt that target boards would choose a method of transfer that minimized the significance of transactions costs. 
and the adverse allocational consequences of a truly foreclosing lockup are, therefore, also trivial).

\section{b. The Transactions Costs of Pre-Sales}

A pre-sale would occur, for instance, in the following scenario: The target board grants a foreclosing lockup to a recipient bidder. After that, but before the transaction between the target and the recipient bidder is consummated, a higher valuing nonrecipient negotiates with the recipient a deal to outbid the recipient in exchange for an effective reduction in the size of the lockup. ${ }^{209}$

To see why pre-sale costs are unlikely to impede otherwise profitable transactions, consider the fact that the purported resale costs have no pre-sale counterparts. Recall Gilson's argument that the information costs associated with resale may be substantial because "the wheel must be reinvented." 210 In a pre-sale, however, as in an auction, the first wheel is enough. Nothing has changed about the target to make the target more difficult to appraise. Similarly, the potential costs of delay that a series of resales might entail do not exist where pre-sale is possible. ${ }^{211}$ Moreover, the agency-cost concern-that Bidder 1 may resist selling the target to avoid reducing the size of its enterprise-is clearly inapposite in the pre-sale context. If Bidder 1 would be unwilling to strike a deal with Bidder 3, then Bidder 1 would outbid Bidder 3 in an open auction ${ }^{212}$ which would imply, counter to our assumption, that Bidder 1 had a higher reservation price than Bidder 3. Readers might be tempted to infer from the seeming absence of instances in which hostile bidders have transacted with recipient bidders that pre-sale contracting costs are high. In our view, that evidence reflects only the current regime, in which a hostile bidder can have the lockup enjoined by a court. ${ }^{213}$

209. There are a number of ways in which a pre-sale might occur. For instance, the recipient bidder might simply sell the option to the third-party bidder. If the terms of the lockup prevent the recipient bidder from selling the option or stocks to a third party, the recipient bidder can simply pay the third-party bidder some amount to take over the target. Alternatively, the recipient bidder can go to the target and threaten either not to go through with the deal, or to go through with the transaction but then fire the target management thereafter, unless the lockup is reduced to the point where the higher valuing bidder was not foreclosed.

210. See supra text accompanying note 191.

211. See supra text accompanying note 193 .

212. Cf. Schwartz, supra note 10 , at 244 .

213. See supra Part II.B.2.

Indeed, prior to Revlon-that is, before Delaware courts began to enjoin lockups challenged by a higher-bidding nonrecipient-some pre-sales between the recipient and a higher valuing bidder did occur. One such instance involved Baxter Travenol Laboratories' 1985 acquisition of American Hospital Supply Corporation. Prior to Baxter's offer, American had entered into a merger agreement with Hospital Corporation of America (HCA), by which each company's shareholders were to receive stock in a third, newly created entity. This agreement included a lockup provision, exercisable in the event of a competing public offer for American common stock, which allowed for either party to exchange 29.5 million shares (25\%) of HCA's newly issued common stock for 39 million' shares (35\%) of American's outstanding common stock. It also required both parties to vote these exchanged shares in favor of the proposed agreement and against any competing offers. Nevertheless, when Baxter tendered an offer for American 


\section{c. The Possibility of Reputational Foreclosure}

It might be argued that, in a regime such as we propose in which courts enforce all lockups subject only to the business judgment rule (a "full enforcement regime"), some acquirers would have an incentive to make and abide by implicit contracts ${ }^{214}$ with target boards to retain target managements even when bargaining with a higher valuing bidder is feasible. By forgoing the immediate gains of resale or pre-sale, those acquirers might enjoy greater, long-term reputational gains. ${ }^{215}$ An acquirer reputed to maintain target managements would likely enjoy preferred treatment, including, perhaps, a foreclosing lockup from disloyal target boards in takeover contests. Those reputational benefits could have the effect of increasing the acquirer's valuation of a target. Where the expected reputational gains of such a strategy in a transaction (call them $R$ ) exceed the difference between the recipient bidder's valuation (absent reputational considerations) and the highest valuing bidder's valuation, there will be no gains to trade from resale or pre-sale.

that was $45 \%$ higher than HCA's, the proposed merger fell through. As part of the final settlement among the three companies, HCA agreed to relinquish the lockup, accepting a $\$ 200$ million cash settlement from Baxter. Thus, Baxter was able to proceed with its acquisition of American. See Seinfeld v. Hospital Corp. of Am., 685 F. Supp. 1057 (N.D. Ill. 1988) (upholding the final agreement against a subsequent 16(b) action). Even in the shadow of Revlon, nonrecipient bidders occasionally bargain with recipient bidders to reduce a lockup's potential effect. For example, in Tyson Foods, Inc.'s hotly contested 1989 acquisition of Holly Farms Corporation, a rival bidder was allowed to profit from its lockup agreement with the target. In October 1988 Tyson made a cash tender offer for all outstanding shares of Holly Farms' stock; Holly Farms then conducted discussions with potential bidders. Following those discussions, the Holly Farms board authorized the sale of the company to ConAgra. As a prerequisite to its merger proposal, however, ConAgra demanded and received a lockup option on Holly Farms' prime poultry operations, as well as a $\$ 15$ million termination fee and expenses. Tyson immediately challenged the arrangements, and in December of that year the Delaware Chancery Court issued a preliminary injunction enjoining the lockup, the termination fee, and the reimbursement provisions. See In re Holly Farms, No. 10350, 1988 WL 143010 (Del. Ch. Dec. 30, 1988). Holly Farms proceeded to hold an auction, in which ConAgra again emerged victorious. Tyson challenged the auction as having been unfair. The court agreed, stating that the lockup-despite the preliminary injunction-"hung like a shroud over the bidding process, favoring ConAgra and disfavoring Tyson Foods." Nevertheless, it upheld the ConAgra bid as in the best interests of the shareholders. See In re Holly Farms, 564 A.2d 342, 349 (Del. Ch. 1989). At that point, the three parties finally agreed to a settlement, pursuant to which Tyson paid ConAgra $\$ 50$ million, in exchange for which ConAgra dropped its bid and waived its rights under the asset lockup. In June 1989, Tyson acquired Holly Farms, in a stock-swap deal worth $\$ 1.25$ billion. See Deborah Hargreaves, Tyson Makes Meal of Holly Farms, FIN. TIMES, June 28, 1989, at 31.

214. Because, by assumption, the employment agreements are not in the interests of target shareholders, they are unlikely to be explicit. Moreover, there is reason to believe that any sort of long-term employment contracts are implicit. See Andrei Schleifer \& Lawrence H. Summers, Breach of Trust in Hostile Takeovers, in CORPORATE TAKEOVERS, supra note 84, at 33 . In any case, if the agreement is explicit, courts probably would not-and as we argue below, should not-enforce such contracts. See infra text accompanying note 240 .

215. Cf. Schleifer \& Summers, supra note 214, at 39 ("A standard solution to the problem of how implicit contracts are maintained is the theory of rational reputation formation . . . In this theory managers adhere to implicit contracts because their adherence enables them to develop a reputation for trustworthiness, and thus to benefit from future implicit contracts. If violating an implicit contract today would make the managers untrustworthy in the future, they will uphold the contract as long as the option of entering into future contracts is valuable enough. Conversely, if it is not important for the managers to be trusted in the future, that is, if a reputation is not valuable, they will violate the implicit contract."). 
That possibility is depicted in Figure 6. Suppose that Bidder I values target at $V_{l}$, excluding reputational effects, and that Bidder 3 values target at $V_{3}$. Suppose further that the target granted to Bidder 1 a foreclosing lockup in exchange for Bidder 1's bid of $B_{r}$. Under those assumptions, as argued above, Bidder 3 would win the target by negotiating directly with Bidder 1 . Now suppose, however, that Bidder 1 (but not Bidder 3) stands to enjoy reputational benefits from maintaining incumbent management and that, adding those external reputational benefits, Bidder 1 values the target at $V_{l}^{R}$. Bidder 1's total gains from winning would actually be $V_{1}^{R}-B_{1}$. A portion of that total gain would include the gains from the particular transaction, $V_{1}-B_{1}$, and a portion would be attributable to the reputational effect of holding onto incumbent management, $V_{1}^{R}-V_{1}=R$. Whenever reputational gains, $R$, exceed potential gains to resale or pre-sale, $V_{3}-V_{1}$, the recipient bidder would refuse to sell to a higher valuing bidder even where the transactions costs of such an arrangement would be trivial. ${ }^{216}$ In this way, therefore, disloyal boards may be able to foreclose higher valuing bidders.

216. To be clear, by a "higher valuing bidder" we mean to exclude the reputational benefits that might accrue to the recipient bidder. It is only because of the extrinsic reputational effects that the lower valuing recipient bidder might act as if it were higher valuing and that this potential impediment to efficient contracting might arise. 


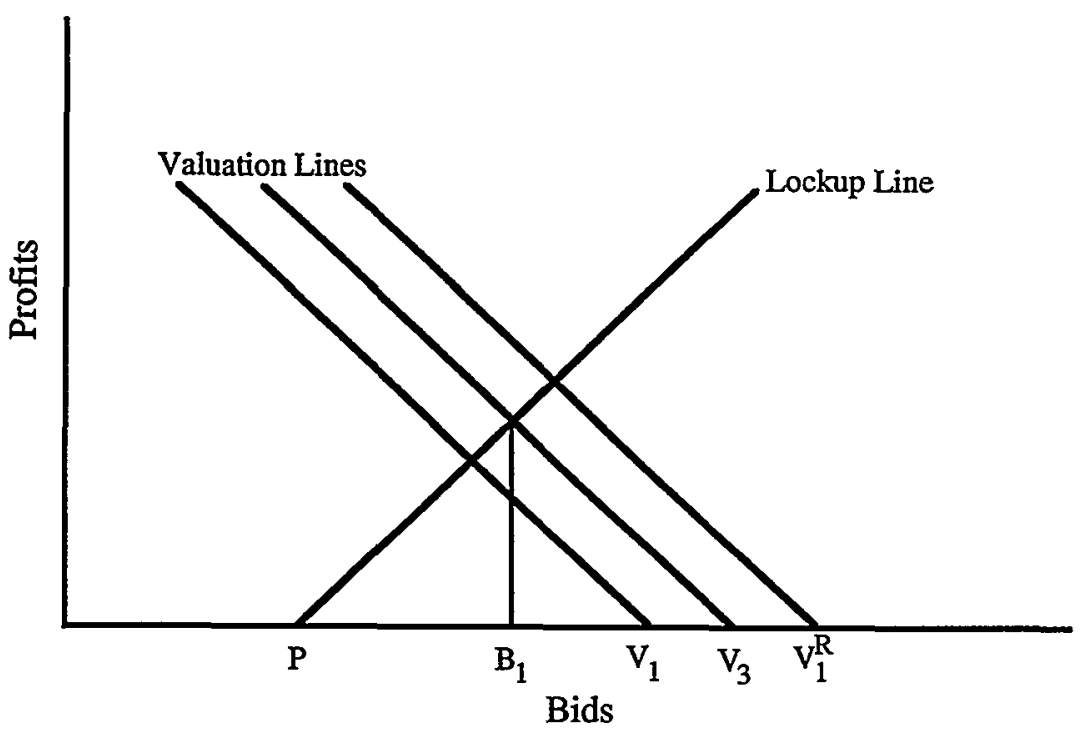

FIGURE 6. Reputational Foreclosure

Courts and scholars analyzing lockups have not previously considered the possibility of this type of foreclosure-call it "reputational foreclosure."217 Indeed, Ian Ayres' analysis, like ours to this point, implicitly depends on the assumption that reputational foreclosure poses no significant threat to allocatively efficient contracting. How might such an assumption be justified?

217. It does not appear that bidders are currently or have ever been motivated by this type of promanagement reputational concern. For example, shortly after Forstmann Little's $\$ 1.5$ billion acquisition of General Instrument Corp. in 1990, the management at General Instrument was replaced by an entirely new management group headed by Donald Rumsfeld. See Daniel F. Cuff, Rumsfeld Becomes Chief at General Instrument, N.Y. TIMES, Oct. 5, 1990, at D3. Similarly, shortly after KKR's $\$ 27$ billion acquisition of RJR Nabisco in 1989, RJR Nabisco's management was replaced by a new group headed by Louis Gerstner. See Jesus Sanchez, RJR Nabisco Hires Gerstner as CEO, L.A. TIMES, Mar. 14, 1989, at 3. Neither Rumsfeld nor Gerstner had been previously employed by General Instrument or RJR Nabisco, respectively. Of course, the current regime may be a poor predictor for acquirers' behavior in the full-enforcement regime that we propose. In the current regime, reputational foreclosure is impossible because lockups are unenforceable. Still, the current regime may be somewhat of an indicator inasmuch as there is a general sense that, even without an enforceable lockup, a bidder with the target board's cooperation has an advantage over other bidders. Cf. John C. Coffee, Jr., Regulating the Market for Corporate Control: A Critical Assessment of the Tender Offer's Role in Corporate Governance, 84 COLUM. L. REV. 1145, 1233 (1984) (explaining that a friendly bidder "can obtain access to whatever it wants in terms of the target's internal reports and projections" whereas a hostile bidder "will typically be denied access to nonpublic data": "Having more information, [the friendly bidder] faces less uncertainty about the target's future earnings stream, and is less likely to make an ill-informed strategic blunder."); Kraakman, supra note 142, at 910 ("The exchanges of information and warranties that characterize friendly acquisitions highlight the uncertainties facing hostile acquirers."). In any event, the fact that bidders do not appear to have attempted to cultivate a pro-targetmanagement reputation prior to the Revlon decision further indicates that reputational foreclosure would not be a serious concern under a full enforcement regime. 
As a starting point, it is important to recognize that to enjoy the benefits of reputational foreclosure, a reputational acquirer must be able to commit credibly to a target's incumbent managers not only that the acquirer will keep management if it gains control of the target, but also that it will refuse any offer from a higher valuing bidder to resell or pre-sell the target. However, as game theoreticians have demonstrated, credible reputational commitments are not easily made in finitely repeated games. ${ }^{218}$ Suppose target boards perceive a reputational acquirer as likely to make a total of twenty acquisitions. At the beginning of its acquisition program, that acquirer might like to cooperate with the first target board in order to establish a reputation from which it might benefit in the next nineteen transactions. However, such a strategy would not succeed, because the acquirer's commitment to cooperate is not credible to target managements, regardless of the bidder's behavior in the first transaction. To see why that is true, notice that the bidder in its twentieth acquisition will have no reputational reasons for cooperating with the target management and will therefore either fire the management or resell or pre-sell the target to a bidder who will fire the target management. Because the acquirer's promise to cooperate with management in the last repetition of the game is not credible, neither will be its promise to cooperate in the next-to-last repetition. Because it is evident that the reputational acquirer will defect in the final repetition, the acquirer might as well defect in the nineteenth repetition, and, hence, the eighteenth, and so on. ${ }^{219}$ In this way, finitely repeated games tend to unravel. Thus, inasmuch as acquirers are not infinitely repeating players, the threat of reputational foreclosure seems slight. ${ }^{220}$

Where an acquirer is itself publicly traded, there exists another impediment to establishing a management-friendly reputation. Even if target boards could trust the managers of acquiring firms, that's not enough. Paraphrasing Schleifer

218. See Reinhard Selten, The Chain Store Paradox, 9 THEORY \& DECISION 127 (1978). As a general matter, only financial buyers-that is leveraged buyout groups-might be characterized as repeat players in recent years. During periods when conglomerates have engaged in diversification-driven acquisitions, some companies have been repeat players (c.g., IT\&T, Gulf \& Western, and United Technologies). Whether target boards might perceive any acquirers as infinitely repeating players is unclear. $C f$. John $\mathrm{C}$. Coffee, Jr., Unstable Coalitions: Corporate Govemance as a Multi-Player Game, 78 GEO. L.J. 1495, 1543 (1990) (stating, on one hand, that at least for management and employees of a target "takeovers are seemingly oneshot affairs," and on the other hand, that for institutional investors in the target, "takeovers are a recurring game in which norms of reciprocity can develop," but taking no position with respect to acquirers). In any case, infinitely repeated games do not necessarily produce a unique, much less a desirable, equilibrium. See ERIC RASMUSEN, GAMES AND INFORMATION: AN INTRODUCTION TO GAME THEORY 92 (1989) (describing the Folk Theorem).

219. Id. at 88. Any game theoretic attempt to solve the problem of unraveling in finitely repeated games creates a problem of multiple equilibria. Ian Ayres, Playing Games with the Law, 42 STAN. L. REV. 1291, 1310-11 (1990) (reviewing RASMUSEN, supra note 218); $c f$. THOMAS HobBes, LeviaTHAN 71 (J.M. Dent \& Sons Ltd. 1973) (1651) ("[t]he bonds of words are too weak to bridle mens . . avarice").

220. In other contexts, cooperation between two players may emerge if those same two players will interact indefinitely (as opposed to infinitely) into the future. See generally ROBERT AXELROD, THE EVOLUTION OF COOPERATION (1984) (describing the success of TIT FOR TAT strategy for promoting cooperation in prisoner's dilemma settings). However, because a target board will not interact with a particular bidder more than once, this sort of cooperation seems unlikely to emerge. 
and Summers' well-known insight, if target boards cannot trust shareholders of acquiring firms, then target managements "would never enter into implicit contracts. To convince [target boards] that implicit contracts are good, shareholders must be trusted not to breach [those] contracts even when it is value maximizing to do so."221 As Schleifer and Summers' analysis makes clear, however, such trust is not possible when the reputational acquirer can itself be acquired in a hostile takeover. Where the reputational acquirer's management is committed to keeping its implicit agreement with the target's board, the reputational acquirer's shareholders can opportunistically create substantial profits by selling their shares to a nonreputational acquirer, who in turn would oust the initial acquirer's management and would disregard any implicit contracts. In that way, "[s]hareholders can ... renege on those contracts and expropriate rents from [managements of the initial targets]. Hostile takeovers thus enable shareholders to redistribute wealth from [the initial target managers] to themselves." ${ }^{222}$ An implicit promise made by a publicly traded acquirer may therefore be of little value. ${ }^{223}$

Even if an acquirer could somehow credibly commit to a pro-targetmanagement strategy, such a strategy seems unlikely to be profitable. The above discussion argued that a bidder's loyalty to a target's incumbent management would affect the bidder's reputation but assumed implausibly (and implicitly) that the bidder's loyalty to a target management had no effect on the bidder's valuation. When that assumption is relaxed, it is simple to see that any reputational advantages (causing an effective increase in Bidder 1's valuation to $V_{l}^{R}$ ) will be offset-perhaps more than fully offset-by a reduction in bidder's valuation in the target itself. An acquirer intending to keep target managements is likely to place a much lower value on any given target (reputational considerations to one side) than other bidders interested in the target. That is true, in part, because bidders who are not concerned about the reputational consequences of a particular acquisition will feel free to replace the target's incumbent management, which, by hypothesis, decreases the target's value. ${ }^{224}$ Accordingly, the reputational benefits of a takeover would have to be fairly significant to make the strategy worthwhile.

221. Schleifer \& Summers, supra note 214 , at 38.

222. Id. at 41 . Schleifer and Summers' insights provide a specific example of the well-known legal maxim that implied contracts aren't worth the paper they're written on.

223. Our textual discussion assumes that managements cannot defend against takeover attempts. If we were to assume instead that managements can resist takeovers, then an acquirer's reputational investments would not be lost. But that does not imply that courts should not, in such a regime, enforce lockups. After all, in a regime where lockups are not enforced, disloyal boards will still be able to entrench incumbent managements simply by resisting any and all sales to any bidder. Thus, where lockups are disallowed, disloyal boards could still protect their jobs at a price to target shareholders. In such a regime, shareholders would prefer that lockups be enforceable inasmuch as lockups would at least ensure that assets moved to higher valuing bidders, even if not to the highest valuing bidder.

224. Recall that we are assuming that the target management has a conflict of interest, which implies that incumbent managers' jobs are at risk and, thus, that incumbent managers do not add much value to the target corporation. See infra text accompanying notes 273-76. 
But that is not the worst of it. Because the acquirer pursuing this strategy places its reputation on the line once it acquires a given target, the valuedecreasing characteristics of the target board will actually be amplified by the acquisition. That is, the strategy of reputational foreclosure would likely increase, not decrease, the agency costs of the incumbent management under new ownership. That is true simply because, whereas shareholders have some ability to dispose of ineffective managers, ${ }^{225}$ the bidder exercising reputational foreclosure has virtually guaranteed the incumbent managers their job security; replacing or firing incumbent managers would destroy any reputational effects that the bidder had established-effects that reach well beyond that specific transaction. By firing one management, the acquirer reduces the trust that subsequent target boards will place in the acquirer's implicit promise and the value of reputational investments made in previous acquisitions. The problem is that, unlike other reputational investments that economic actors might make, investments in reputational foreclosure would actually create a moral hazard problem, which would eat up some or all of the reputational gains to the strategy. ${ }^{226}$ Because any one target must be one of a significant number of targets that the acquirer hopes to acquire with this strategy, there is a strong incentive on each individual target management to shirk once purchased by the acquirer. On one hand, the acquirer will go to great lengths not to fire a given target management since doing so would substantially injure the acquirer's reputation. ${ }^{227}$ On the other hand, if the

225. Shareholders' ability to force out incumbent managements has become increasingly evident in recent years. For example, the CEO of Borden was forced to resign after certain financial institutions owning large amounts of Borden stock communicated their displeasure with management to Borden's outside directors. The outside directors, spurred by the shareholders, then retained separate legal counsel and financial advisors and attempted unsuccessfully to cause the sale of the company. Unable to obtain an acceptable price, the outside directors then ousted the CEO and replaced him with a nonemployee chairman of the board and a new CEO, who had previously been the chief operating officer. See Alison L. Cowan, Borden's Board Ousts Chief To Calm Investors, N.Y. TIMEs, Dec. 10, 1993, at D1. Similar stories have, in recent years, taken place at Allied Signal, see Amal K. Naj, Sudden Shift: Hennessey Is Retiring at Allied-Signal Inc., Sooner than Expected; Board Names GE's Bossidy, Gives Him Broad Mandate To Reshape Conglomerate, WALL ST. J., June 27, 1991, at A1; American Express, see Brett D. Franson, American Express: Anatomy of a Coup, WASH. POST, Feb. 11, 1993, at A1; Eastman Kodak, see John Holusha, Eastman Kodak Chief Is Ousted by Directors, N.Y. TIMES, Aug. 7, 1993, at A37; General Motors, see Doron P. Levin, G.M. Board Makes Sweeping Changes in Executive Suite, N.Y. TIMES, Nov. 3, 1992, at Al; Goodyear Tire and Rubber, see Peter NuIty, The Bounce Is Back at Goodyear, FoRTUNE, Sept. 7, 1992, at 70; IBM, see Jonathan Weber, IBM To Replace Chief Executive, Slash Dividend, L.A. TIMES, Jan. 27, 1993, at A4; Tenneco, see Vineeta Anand, In Removing CEO's Boards Send Signal to Holders, INVESTORS Bus. DAILY, Nov. 20, 1992, at A1; and Westinghouse, see Suzanne Bilello, Westinghouse Ousts CEO, N.Y. NEWSDAY, Jan. 28, 1993, at 37. For a superb account of a strategy that shareholders could employ to discipline corporate managers, see generally Grundfest, supra note 5.

226. For more general discussion of the moral hazard problem in insurance contracts, see Jon D. Hanson \& Kyle D. Logue, The First-Party Insurance Externality: An Economic Justification for Enterprise Liability, 76 CORNEll L. REV. 129, 138-39 (1990). See also Mark V. Pauly, The Economics of Moral Hazard: Comment, 58 AM. ECON. REv. 531 (1968); Kenneth J. Arrow, The Economics of Moral Hazard: Further Comment, 58 AM. ECON. REv. 537 (1968).

227. In the same way that first-party insurers will often compensate insureds to whom they are not contractually bound in order to preserve their "good hands" reputations, an acquirer's ability to control this moral hazard problem is severely constrained by reputational concerns. See H. LAWRENCE ROSS, SETTLED 
acquirer does fire the management of one previously acquired target, it will have less reason not to fire the value-decreasing managements of all previously acquired targets, given the adverse consequences that the first firing will likely have on its reputation. Consequently, the management of each acquired target will recognize that its job security is largely independent of its performance. Because managements can, in this way, externalize the costs of shirking, and because shirking brings utility to managements, managements of acquired targets will have a strong incentive to shirk. ${ }^{228}$ Because the strategy of reputational foreclosure is unlikely to succeed, bidders are unlikely to attempt such a strategy and, in any case, target managers are unlikely to give them the opportunity.

For all these reasons, it appears that the threat of reputational foreclosure is probably remote. But even if the threat were real, an analogous threat to target shareholders would exist in a regime that did not enforce lockups. That is, if a bidder could establish a reputation in a full-enforcement regime for refusing to resell or pre-sell targets no matter how attractive the terms of the offer, it would seem that that same bidder could establish a reputation in a non-enforcement regime for winning every auction contest it entered, no matter how high the escalation of bids. Once established, the bidder's reputation would deter competition in subsequent auctions, and the bidder would obtain targets at lower prices than it would have to pay under a full-enforcement regime. ${ }^{229}$ In sum, either reputation poses no significant threat to target shareholders, or the threat that it does pose exists regardless of whether lockups are enforced.

\section{Summary}

It may be instructive to note that the participants on both sides of the classic auction debate ${ }^{230}$ might-forced by the terms of their own reasoning

OUT OF COURT: THE SOCIAL PROCESS OF INSURANCE ClAIMS ADJUSTMENTS 233-42 (1970) (describing insurer's reluctance to withhold payments even when it is entitled to them by the terms of the insurance contract).

228. This is another version of the tragedy of the commons. See generally Garrett Hardin, The Tragedy of the Commons, 162 SCIENCE 1243 (1968).

If agency costs could be eliminated in a fairly straightforward structural way, by, for example, increasing the target's debt load, see, e.g., Michael C. Jensen, Takeovers: Their Causes and Consequences, $2 \mathrm{~J}$. ECON. PERSP. 21 (1988) (explaining the role of increased debt as a potential source of takeovers), then the law regarding lockups would likely have no significant effect. If target boards are permitted to resist all bidders, and lockups are not enforced, target boards will never agree to sell; and, where lockups are enforced, target boards will agree to sell to specific buyers. On the other hand, if full resistance is not permitted, target boards, deterred by the threat of takeover, will change their firm's debt load in order to keep their jobs where lockups are not enforced or will be forced by their acquirer to do so where lockups are enforced.

229. See infra Part III.C.3 (explaining how lockups are a defense to analogous strategies); see supra note 51 and accompanying text (explaining how the lockup in Revlon may have been justified as a defense against a similar strategy).

230. See supra note 188 and accompanying text. 
and notwithstanding their previous conclusions to the contrary-now accept our conclusion that lockups pose no threat to allocational efficiency. To see why, it is important to understand that that debate was, at root, a debate over how much time or delay should separate the initiation and the completion of a takeover transaction. ${ }^{231}$

As we argued above, those who disfavor the auctioneering rule believe that the transactions costs of resale are trivial. From their perspective, therefore, there are no benefits (only costs) to a rule that creates delay and allows thirdparty bidders to enter the fray. ${ }^{232}$ In light of their own view that resale costs are insignificant ${ }^{233}$ (and our arguments that pre-sale costs are lower still ${ }^{234}$ ), however, they should agree that lockups cannot have adverse allocational consequences. Assets will, one way or another, move to their highest valued use.

Those who favor an auctioneering rule are less sanguine about resale costs. They favor an auctioneering rule as a way of ensuring that higher valuing bidders have enough time to mount their own tender offers. Delay, according to those scholars, is the necessary and sufficient ingredient to allocational efficiency. ${ }^{235}$ Based on that reasoning, however, those scholars cannot maintain their view that lockups impede allocatively efficient transfers. That is true because lockups will only be valuable in cases where third-party bidders have adequate time in which to offer a competing bid. If that were not the case, the lockup would serve no purpose-competitors would already be temporally foreclosed. (Indeed, a loyal target board might actually grant a lockup in order to purchase such a delay or, in other words, buy time, from the recipient bidder so that other bidders might join the auction. ${ }^{236}$ ) The existence of a lockup, therefore, provides evidence that there exists an adequate delay for third party bidders to mobilize and compete. ${ }^{237}$ Because lockups

231. See, e.g., Bebchuk, supra note 9, at 25 ("The question of whether management should be allowed to provide information to potential buyers is indeed of limited importance: As long as a regulatory delay is provided, an active competition among acquirers will take place even if management must remain passive. But the prescription of this crucial delay, which Easterbrook and Fischel oppose and I endorse, is of great moment."); $i d$. at $25 \mathrm{n} .8$ ("Time is obviously necessary for tender offers by rival potential buyers."); Bebchuk, supra note 10, at 254 ("Time is crucial for competing bids, and the Williams Act, which the proauctioneering view endorses, provides time by prescribing a mandatory delay period. Those who hold the antiauctioneering view would have us repeal the Williams Act: they would like us to return to a regime of Saturday-Night Special Bids . . that is, offers that are open for a very brief period . . .."); see also supra note 155 (other authors concemed with time duration of transactions).

232. They argue that allowing other bidders to compete for the target reduces the returns to the initial bidder and thus fails to provide optimal incentives for bidders to search. For that reason they urge repeal of the Williams Act, which creates a mandatory time lag. See generally Easterbrook \& Fischel, supra note 9; Schwartz, supra note 10. Below, we briefly discuss the effects lockups have on search. See infra Part III.C.2.d.

233. See supra Part III.A.2.a.

234. See supra Part III.A.2.b.

235. See supra note 231.

236. See supra note 155 and accompanying text.

237. It is not necessarily the case that delays will always accompany lockups; it is simply the case that (i) there is no purpose served by a lockup where there is not adequate delay (there is already temporal 
will be relevant only where third-parties have the opportunity to compete for the target, proponents of the auctioneering rule should agree that lockups pose no threat to the goal of allocational efficiency. ${ }^{238}$

We have argued that there is little if any relevant friction between a recipient bidder and a higher valuing nonrecipient bidder, especially in the presale context. ${ }^{239}$ Of course, lockup arrangements may be written in a way that discourages resales or pre-sales and, to that extent, protect a target management's disloyal pursuit of job security. ${ }^{240}$ If there were such a concern, however, courts could eliminate it by simply refusing to enforce any substantial contractual limitations on the recipient bidder's ability to resell or pre-sell the lockup.

If transactions costs are irrelevant, as we have argued they are, then incumbent managements hoping to secure their jobs will be unable to do so by granting lockups that "foreclose" higher valuing bidders. Thus, it appears that "foreclosure" should be neither a necessary nor a sufficient condition for enjoining a lockup. Put differently, accepting the premise of the ex post approach that courts should invalidate only lockups that foreclose higher

foreclosure of other bidders), and (ii) where delay does not accompany a lockup, the lockup is not the source of the foreclosure.

238. This assumes that the costs to the third party of negotiating with the recipient bidder in a pre-sale are not significantly greater than the cost to the third party of negotiating with the target board or of competing in an auction for the target. Since courts and scholars have not argued that the latter costs are inherently transaction-prohibitive, it seems fair to assume that neither are the former. $C f$. Bebchuk, supra note 10, at 268 ("[T]he costs of making competing bids . . . are a small price to pay for ensuring an efficient allocation of target assets.").

239. To be clear, our claim is not that resales and pre-sales are frictionless. It may well be, for instance, that there are some contracting costs stemming from "strategic behavior" on the part of Bidder 1 and Bidder 3. See A. MrTChell Polinsky, AN INTRODuCTION TO LAW AND ECONOMICS 18 (2d ed. 1989) (briefly describing certain types of strategic behavior and treating strategic behavior as type of transactions cost); POSNER, supra note 53, at 61-62 (describing the strategic behavior costs associated with "bilateral monopoly"). Our claim is a weaker one that the transactions costs of resale and pre-sale are no higher than those between the recipient bidder and the target board. Neither courts nor commentators have suggested that the latter costs are large enough to justify any type of regulatory intervention.

240. In fact, many lockups impose limitations on transferability, though such restrictions are waivable. See, e.g., Stock Option Agreement Between Viacom, Inc., and Paramount Communications, Inc., dated Sept. 12, 1993 (on file with author) ("This Agreement shall not be assigned by operation of law or otherwise, except that Viacom may assign all or any of its rights and obligations hereunder to any wholly owned subsidiary of Viacom, to National Amusements, Inc. or to a voting trust pending receipt of FCC approval relating to exercise of the Stock Option by Viacom, provided that no such assignment shall relieve Viacom of its obligations hereunder if such assignee does not perform such obligations."). Such limitations seem unlikely to significantly impede transfer of the target to the nonrecipient bidder. That is true, first, because those limitations have no effect on a recipient bidder's ability to resell the target. Second, when a recipient bidder would like to pre-sell the target, it would likely have no difficulty obtaining a waiver of those restrictions from the target board. Because of a target board's fiduciary obligations to its shareholders, it is in no position to turn down the higher bid of the third-party bidder when the recipient bidder wants out of the deal. See supra notes $209 \& 213$. 
bidders, and accepting our arguments that foreclosure is unlikely ever to occur, leads to the conclusion that courts should enforce all lockups. ${ }^{241}$

\section{B. Maximizing Target Shareholder Returns}

From the perspective of many legal economists, the only goal of the laws governing lockups should be the efficiency goal of moving resources to their highest valued use. ${ }^{242}$ For the reasons we have discussed, it appears that that goal would be met were courts to enforce all lockups, subject only to the business judgment rule-a "full enforcement regime." ${ }^{243}$ Thus, assuming they accept our arguments, those legal economists should agree that we have made a case for unlocking lockups. But courts and some legal scholars seem concerned not just about that efficiency goal but also about maximizing revenues for target shareholders. ${ }^{244}$ Many legal economists agree that the revenue maximization goal is merely an artifact "of the way takeover litigations are conducted, [and] has no intellectual support."245 Although we share the view that the goal of maximizing revenues for its own sake lacks normative force, ${ }^{246}$ those courts and commentators who do subscribe to that goal may be reassured to learn that, as this Section argues, a full enforcement regime would likely maximize shareholder revenues at the same time that it serves allocative-efficiency goals. Indeed, as Section C argues below, a full enforcement regime will better serve that goal than does our current nonenforcement regime.

\section{Management's Incentive To Maximize Share Price}

Target boards often have strong self-interested motives to maximize share price. For instance, target board members typically own a quantity of target

241. If, even in a regime in which lockups are enforced, contracting costs were transaction-prohibitive, our argument would be weakened. But if contracting costs created a significant impediment to contracting, that may imply only that policymakers should focus on lowering those contracting costs, not necessarily that lockups should be invalidated.

242. See, e.g., Cramton \& Schwartz, supra note 2, at 28.

243. See also infra Part III.B.1 (providing additional reasons why target boards will seek to sell to highest valuing bidder).

244. See, e.g., Paramount Communications, Inc. v. QVC Network, Inc., 1994 WL 30181 (Del. Feb. 4, 1994); Revlon, Inc. v. MacAndrews \& Forbes Holdings, Inc., 506 A.2d 173, 182 (Del. 1986) (holding that when corporation is "for sale," fiduciary role of board shifts from that of defender to that of auctioneer charged with obtaining "best price" for its shareholders); accord Mills Acquisition Co. v. Macmillan, Inc., 559 A.2d 1261, 1286-87 (Del. 1989).

245. Cramton \& Schwartz, supra note 2, at 29; see also Schwartz, supra note 10, at 244-49. Cf. Bebchuk, supra note 9, at 27 (stating that he finds the shareholder perspective less "congenial" than the efficiency perspective).

246. Some legal economists have suggested that by satisfying the goal of revenue maximization, courts satisfy several worthwhile efficiency goals. See, e.g., Bebchuk, supra note 190, at 1048-50. 
shares that is substantial in relation to each board member's wealth. ${ }^{247}$ To maximize the value of those shares (which, of course, means maximizing the value of all shares), the target board will seek not only to sell to the highest valuing bidder, but also to extract as high a bid as possible from that bidder. $^{248}$

Consider also the prevalence of so-called "golden parachute" agreements. Now in place in more than half of all publicly held companies, ${ }^{249}$ these agreements essentially guarantee a company's officers and directors lucrative cash payments and other benefits in the event that they should lose their jobs under new management. ${ }^{250}$ Proponents argue that golden parachutes, by providing a measure of security to corporate executives, free those officers to assess various takeover offers without concern for personal finances. ${ }^{251}$ On the other hand, opponents charge that these agreements go too far, overcompensating executives ${ }^{252}$ to the extent that they have an incentive to

247. Harold Demsetz, The Structure of Ownership and the Theory of the Firm, 26 J.L. \& ECON. 375, 388 (1983) (finding that managers and directors own substantial blocks of employing firm's shares-usually 20 \%o or more-except in largest corporations); Morck et al., supra note 84, at 107 (reviewing data regarding stock ownership of insiders).

248. Cf. William J. Carney, Controlling Management Opportunism in the Market for Corporate Control: An Agency Cost Model, 1988 WIS. L. REv. 385 (arguing, in essence, that the stock-price incentive can swamp the job-security incentive); Walkling \& Long, supra note 84 (providing evidence that target managements are less likely to contest an offer as percentage of pre-bid board stock ownership rises). This is an old principle: Partial ownership on the part of managers may substantially lower the agency costs resulting from the separation of ownership and control. See, e.g., CLARK, supra note 1, at 202 (an executive will be "interested in making the company perform so as to be well received by securities analysts and investors, for he may make a profit if the market price of [his corporation's] stock increases"); EASTERBROOK \& FISCHEL, supra note 5, at 9 ("Another way around the difficulty of monitoring . . . is to give each the right to some profits from the firm's success. Each then will work hard and monitor the work of colleagues, lest their subpar performance reduce his rewards."); id. at 10 ("When managers hold the stock of their firm, they are 'bonding' their performance (in part) by exposing their wealth to erosion if their performance, and hence the firm's profits, is substandard."). See generally Armen A. Alchian \& Harold Demsetz, Production, Information Costs, and Economic Organization, 62 AM. ECON. REV. 777 (1972). For an overview of the types of "incentive compensation plans" that are commonly used in large corporations, see CLARK, supra note 1, at 202-09. Under the assumption that defensive tactics were prohibited, Ronald Gilson writes:

[W] substantial incentive, ... undiluted by the option of continued independence, to sell the company in a fashion that allows them to share in the gain. This is not to say that management would not prefer to remain independent, but only that, when remaining independent has been made more difficult, if not impossible, by the prohibition of defensive tactics, management's second best solution may be to actively promote the sale of the company.

Gilson, Seeking Competitive Bids, supra note 190, at 67 n.36; see also Bebchuk, supra note 190, at 1041-46 (discussing how stock ownership gives seller's management the right incentives to sell); Easterbrook \& Fischel, supra note 9, at 12 (conceding that auctions "induce managers of potential targets to look for appropriate acquirers").

249. EXeCUTIVE COMPENSATION REPORTS, ECR 1993 Golden PARACHUTE REPORT 1.

250. EXECUTIVE COMPENSATION REPORTS, GOLDEN PARACHUTE AND SEVERANCE ARRANGEMENTS REPORT, Monograph Series 3 (1991).

251. See, e.g., David V. Maurer, Comment, Golden Parachutes-Executive Compensation or Executive Overreaching?, 9 J. CORP. L. 346, 351-52 (1984).

252. Severance provisions are typically tied to some multiple of the executive's base salary, and can run into the millions of dollars. 
encourage takeovers not otherwise in the shareholders' interests. ${ }^{253}$ In either case, for the majority of today's top executives, negotiating a side guarantee of job security with a bidder for the company is virtually unnecessary. Thus, "management entrenchment" may, in reality, not be quite the problem that courts and scholars have made it out to be. ${ }^{254}$

In any event, lockups under a full enforcement regime would satisfy shareholders' goal of maximizing share price simply because, as argued above, a target board is likely unwilling and unable to use lockups to satisfy any disloyal job-entrenchment ends. ${ }^{255}$ For that reason, target boards are entitled to the business judgment rule presumption that they are pursuing loyal ends which, of course, include the goal of maximizing shareholder revenues. ${ }^{256}$

\section{Can Nonforeclosing Lockups Be Disloyal?}

Like others calling for an ex post approach to lockups, we have thus far overlooked a potential problem with the goal of ensuring that lockups not foreclose higher valuing bidders. ${ }^{257}$ Even if that goal is satisfied, as we have argued it would be, a disloyal target board may be able to entrench target management by granting a lockup to the highest valuing bidder, that precludes lower valuing bidders who value the firm at more than the recipient bidder's bid. $^{258}$

253. See, e.g., Robert W. McGee, Mergers and Acquisitions: An Economic and Legal Analysis, 22 CREIGHTON L. REV. 665, 676-78 (1989).

254. See supra note 9.

255. See supra Part III.A.1-2.

256. See supra text accompanying note 20 .

257. It is important to recognize that the goal of not foreclosing higher valuing bidders stems from either or both of the more specific goals of ensuring allocative efficiency and board loyalty. Ayres conflates the goals of allocative efficiency and managerial loyalty. See, e.g., Ayres, supra note 9, at 684 (stating that foreclosure is undesirable because it "is inconsistent with maximizing shareholder welfare" and implying that nonforeclosure is consistent with that goal). Bainbridge, on the other hand, takes an agnostic position with respect to the efficiency effects of an ex post approach and focuses almost exclusively on "the role of competitive bidding in constraining self-interested behavior by target managers." Bainbridge, supra note 1, at 272. As this Section will make clear, it may be possible to satisfy one goal without satisfying the other.

258. This possible conflict between the goal of allocative efficiency and the goal of shareholder revenue maximization does not arise if the recipient bidder is not the highest valuing bidder, as we have implicitly assumed thus far in our analysis. 


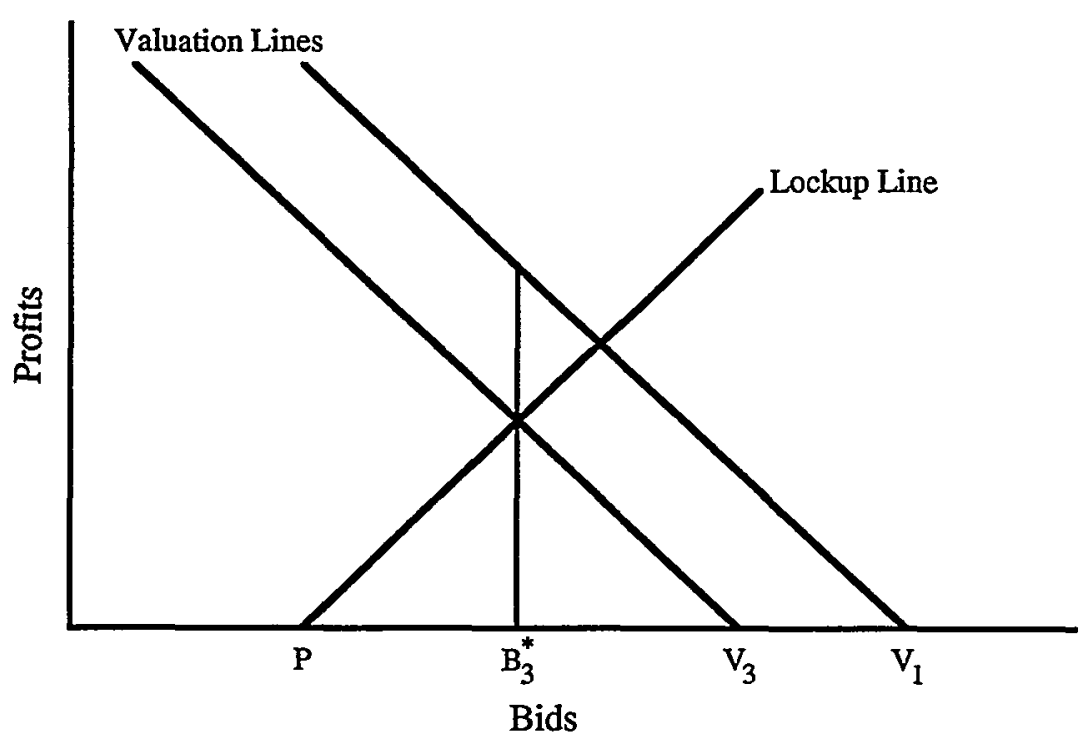

FIGURE 7. Precluding Lower Valuing Bidders

To see how this might occur, assume that the target board can identify which bidder, among all actual and potential bidders, is the highest valuing bidder (Bidder 1 in Figure 6 with a reservation price of $V_{1}$ ) and knows the reservation price $\left(V_{3}\right)$ of the second-highest valuing bidder (Bidder 3$)$. In an open auction, of course, Bidder 1 would win the target with a bid equal to (or just exceeding) $V_{3}$, because Bidder 3 would be unwilling to, and Bidder 1 would neither need nor wish to bid more than $V_{3}$. The target board could then make the following deal with Bidder 1: In exchange for job security, the target board will grant Bidder 1 the lockup depicted in Figure 7. Bidder 1 may well accept such a deal because, given the lockup, any bid that it makes higher than $B_{3}^{*}$ (the lowest bid that forecloses Bidder 3) and lower than $V_{3}$ (the lowest bid that Bidder 1 would have to make absent the lockup) makes Bidder 1 better off. Notice that after the lockup is granted, the nonrecipient bidder will be unwilling, and, hence, the recipient bidder will not need, to bid more than 
$B_{3}{ }^{*}{ }^{259}$ With something of real value to offer Bidder $1,{ }^{260}$ a target board could make and protect a disloyal arrangement with the bidder. ${ }^{261}$

For whatever reasons, scholars focusing on the ex post effects of lockups seem to have overlooked the possibility of such preclusive, "nonforeclosing"

259. Note that Coasean bargaining would not protect shareholders from this disloyal arrangement, because, by hypothesis, there is no positive amount that Bidder 1 would be willing to pay Bidder 3 , and that Bidder 3 would be willing to accept, in order for Bidder 3 to buy the target with the lockup in place. Put more simply, the recipient bidder stands to profit from winning the target. See supra Figure 5 and accompanying text.

260. The value of the lockup to Bidder 1 , therefore, will be:

$V_{3}-B_{3}^{*}=T\left(V_{3}-P\right) /(N+T)>0$.

261. Our analysis has assumed, as is plausible, that the lockup exercise price, $P$, is lower than $V_{0}$. Theoretically (and this is just an aside), a lockup that is not preclusive could actually increase the secondhighest valuing bidder's reservation price. This would be true whenever $V_{3}<P$ and, unrealistically, the costs of participating in an auction are not positive. Algebraically, this is evident from the fact that:

$$
T\left(V_{3}-P\right) /(N-T)<0 \text { whenever } V_{3}<P \text {. }
$$

Graphically, this can be seen by noting that the point of intersection between Bidder 3 's valuation line and the lockup line in Figure 8 occurs at a point to the right of $V_{3}$ (and beneath the original zero-profits line). Drawing a vertical line up from the intersection point gives the new reservation price, $B_{3}{ }^{*}$, which has shifted to the right of the original valuation.

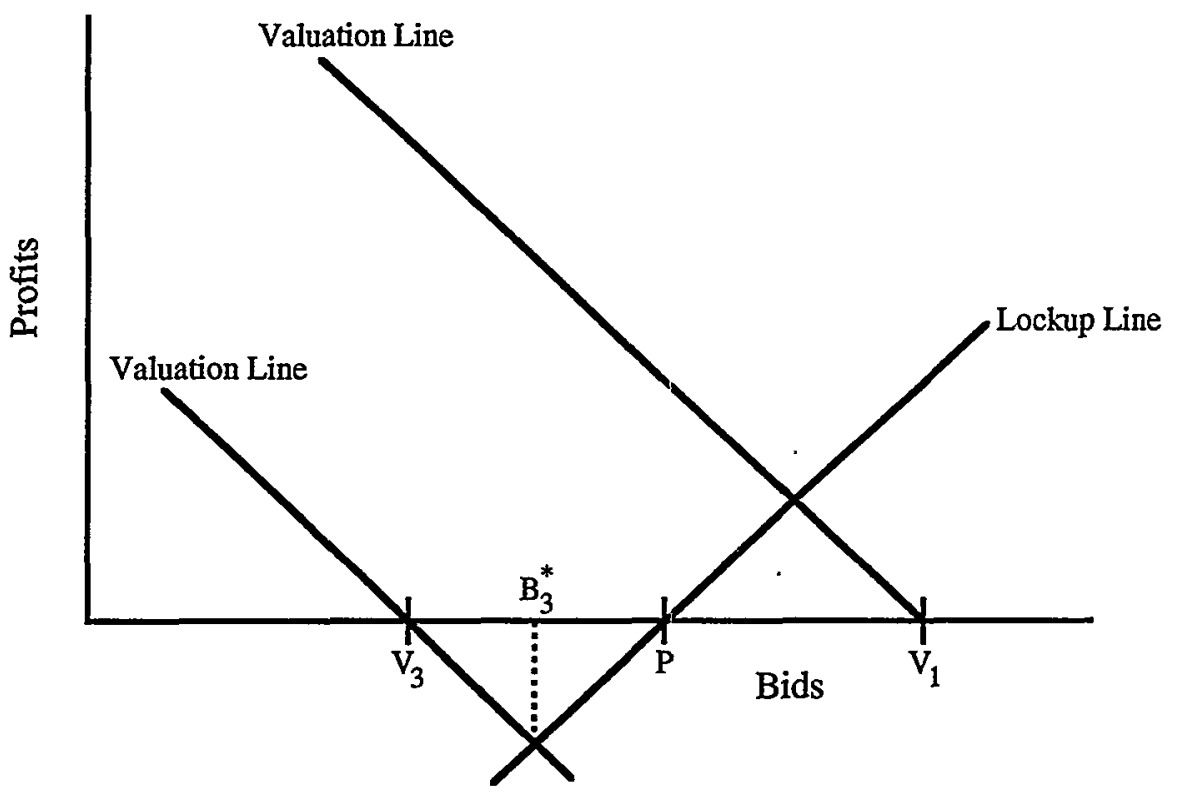

FIGURE 8.

To glimpse the intuition, note that Bidder 3 will now pay for the right to sell the treasury shares to Bidder 1 at the option price. Originally, Bidder 1 would have had to just barely exceed $V$, to secure the company. When Bidder 1 accepts a lockup with an exercise option price, $P$, that exceeds $V_{b}$ there is positive value to Bidder 3 to have those options purchased from him. 
lockups. ${ }^{262}$ But the oversight is harmless, in our view, because the threat posed by such lockups seems de minimis. Lockups granted to the highest valuing bidder, whether or not they foreclose the next-to-highest valuing bidder, still serve the primary efficiency goal of transferring corporate assets to their highest valued use. But even if the law's goal were to maximize the premium enjoyed by target shareholders, target boards are unlikely to want to or be able to foreclose lower valuing bidders.

First, the self-interested motives that managers often have for maximizing the target's sales price will weaken or eliminate their incentive to preclude lower valuing bidders. ${ }^{263} \mathrm{Job}$ security, in other words, has a price that target boards may well be unwilling to pay-that is, the price of forgone earnings from the sale of their shares of target stock. Second, even were a target board willing to pay such a price, the target board is unlikely to be capable of successfully granting a preclusive lockup to the highest valuing bidder in exchange for job security. To see this, it is helpful to distinguish between two types of auction contexts: (1) common-value auctions, in which every bidder places the same value on the target and (2) independent private-value auctions, in which the value of the target differs across bidders. ${ }^{264}$

Many scholars believe that takeover attempts motivated by the goal of displacing the target's bad management are aptly characterized as commonvalue auctions. ${ }^{265}$ Indeed, "[t]he evidence suggests that a majority of hostile acquisitions and management buyouts are common value."266 In such auctions, however, there is no threat of disloyal lockups, because any attempt by a target management to strike a deal with a particular bidder will backfire. If the preferred bidder does agree to keep the target management on board in exchange for a lockup, that agreement will lower the bidder's valuation of the

262. We say "nonforeclosing" because such lockups do not affect the identity of the winning bidder, but "preclusive" because they nevertheless preclude lower valuing bidders from bidding up to their prelockup reservation prices. The rule proposed by Bainbridge and the standards proposed by Ayres to deter foreclosing lockups, would not assist courts in identifying lockups that disloyally preclude lower valuing bidders. A numerical example helps make this clear. Suppose $V_{1}=\$ 115$ and $V_{3}=\$ 110$. In an open auction, Bidder 1 would have to bid $\$ 110$ (or slightly more than $\$ 110$ ) to win the target. The target management may be able to bargain for job security with Bidder 1 by providing a lockup worth $\$ 10$ per share in exchange for a bid of $\$ 100$ from Bidder 1 . Such a lockup would preclude Bidder 3 from bidding over $\$ 100$ per share. Note that neither Ayres' nor Bainbridge's ex post approaches would invalidate such a lockup: The requisite valuation implied by the lockup is only $\$ 110$, clearly within Ayres' range of reasonableness; and the value of the lockup is not greater than Bainbridge's $10 \%$ threshold.

263. See supra notes $247-54$ and accompanying text.

264. For a more complete treatment of these two types of auctions, see Cramton \& Schwartz, supra note 2 , at 28-30.

265. See id. at 47 (explaining further "that acquirers commonly take steps that the targets could have taken and that increase value"); Gilson, supra note 1, at 873; Schwartz, supra note 10, at 243 ("a mismanaged firm is equally valuable to all acquirers because any acquirer could maximize the firm's value"); cf. Bebchuk, supra note 10, at 262 ("When the motivation for acquiring the target is the current undervaluation of the target's stock, the value of the target is presumably the same for all potential buyers."). But see id. at 265 ("acquirers may well differ in their ability to improve the target's management").

266. Cramton \& Schwartz, supra note 2 , at 47 ; see id. at $48-49$. 
target, opening the door for now-higher valuing bidders (because they would be free to fire the managers) to win the target via a resale or pre-sale. ${ }^{267}$ Because a disloyal lockup would not be foreclosing, target managers have no incentive to grant it in the first place. For that reason, managers will grant lockups in common-value auction contexts only where doing so is loyal to shareholder interests. And, as we will make clear in the next Section, there is a very good reason for target boards to grant such lockups in precisely that context. $^{268}$

In independent private-value auctions, such as those motivated by synergistic gains, a lockup is similarly likely to serve only loyal ends. For a target board to succeed in granting a disloyal lockup to the highest valuing bidder, the board must be able to identify that bidder. ${ }^{269}$ There appears to be no dispute, however, that, as in many bargaining contexts, a target board is unlikely to know a bidder's reservation price or, consequently, which bidder among several has the highest reservation price. ${ }^{270}$ As Lucian Bebchuk explains, the takeover context is one in which "each of the parties is uncertain as to the other's valuation of the object to be sold."271 A bidder can claim to be the highest valuing bidder, but such a claim, by itself, is not credible, since it is equally easy for any bidder to make. We know of no effective way for a target board to identify the highest valuing bidder short of requiring each bidder to put its money where its mouth is-or, in other words, holding an auction. ${ }^{272}$ With an auction, of course, the target board can locate the highest valuing bidder by locating the highest bid. That method, however, is selfdefeating: If the target board grants a lockup to the bidder with the highest bid, then there is no reason to worry about the loyalty of the lockup.

267. See supra Part III.A.2.a-b. Consistent with the argument that a promise to retain a bad management may place the bidder at a comparative disadvantage is the evidence that incumbent managers are more likely to be retained in uncontested takeovers. See Walking \& Long, supra note 84, at 6-7.

268. See infra Part II.C.3.

269. See supra text accompanying notes $257-61$.

270. Indeed, if target boards did know bidder's valuations, then holding an auction would arguably be an act of disloyalty, because an auction would fail to maximize the shareholder revenues. $C f$. R. Preston McAfee \& John McMillan, Auctions and Bidding, 25 J. ECON. LIT. 699, 704 (1987) ("If the seller were able to observe bidders' valuations, he could offer the item to the bidder who values it the most at a price slightly below this bidder's valuation, threatening to refuse to sell it if this offer is rejected.").

271. Bebchuk, supra note 10 , at 266 .

272. See Ayres, supra note 9, at 689 (since a bidder cannot "notify the market of how much [a target's] shares [are] worth to him, third parties [can]not . . . determin[e] [the bidder's] reservation price ... with precision"); Cramton \& Schwartz, supra note 2, at 39 ("[W] hen bidder valuations differ substantially, boards seldom could rank these valuations precisely without auctions."); id. (an "auction's object is to induce revelation of these valuations"); $i d$. at 42 ("the auction process is used just because bidder valuations are hard to measure"); McAfee \& McMillan, supra note 270, at 704 ("Asymmetry of information is the crucial element of the auction problem."); $i d$. at 711 ("The essence of the auction problem is the unobservability of bidders' valuations."); Michael H. Rothkopf et al., Why Are Vickrey Auctions Rare?, 98 J. POL. ECON. 94, 102-07 (1990) (arguing that bidders do not want to reveal their valuations because doing so will harm them in their negotiations with later bargaining partners); see also QVC Network Inc. v. Paramount Communications Inc., 635 A.2d 1245, 1268 (Del. Ch. 1993) (explaining that the Revlon duty to conduct an auction is intended to ensure that directors' decisions are adequately informed; "an auction is one way of obtaining information"). 
Moreover, even assuming a target board could easily identify the highest valuing bidder, the target board has little to gain, and may have much to lose, by granting a disloyal lockup in the hope of obtaining job security. Consider three likely possibilities. First, the target's management may be a valuable corporate asset, in which case managers' jobs are unlikely to be at risk. ${ }^{273}$ Consequently, good target managements will not be strongly motivated by jobsecurity concerns when negotiating with the highest valuing bidder. Second, target managers may clearly be a corporate liability. Where that is true, potential bidders are likely to be motivated primarily, if not solely, by the value-increasing goal of ousting the bad management and are likely, therefore, to have roughly equivalent reservation prices. ${ }^{274}$ As we just argued, in such common-value auctions, lockups can serve only a board's loyal ends. Third, a bidder may be uncertain as to whether a target's management is an asset or a liability, and thus uncertain as to whether to retain the target management. In such circumstances, a disloyal act on the part of target management may be all the evidence the acquirer needs to conclude that, as agents, target managers cannot be trusted. ${ }^{275}$ Any chance a target management may have of keeping its job, therefore, may be lost if the target management grants a disloyal lockup. ${ }^{276}$

Even if target boards were capable of recognizing the highest valuing bidder and securing their jobs through a disloyal lockup, there is no way for

273. There may be significant advantages to retaining a target's incumbent management. For instance, a target's management may know more about the target's industry and will almost certainly know more about the target firm than the acquirer does. Sometimes, the job opportunities for good management actually increase in a takeover encounter. One case in point: After an unsuccessful bid to acquire the AllenBradley Company in 1985, see Robert J. Cole, $\$ 1.65$ Billion Rockwell Merger Set, N.Y. TIMES, Jan. 18, 1985, at D1, Forstmann Little arranged for Allen-Bradley's Executive Vice President, Kenneth F. Yontz, to be hired to run Forstmann's newly acquired Sybron Corporation. In 1987, Forstmann sold Sybron in a leveraged buy-out to a newly formed company, whose principal owners were DLJ Capital Corporation, Hicks \& Hass Inc., and certain members of management. Yontz stayed on as the new company's President and Chief Executive Officer, as well as one of its equity owners. Under his ongoing tenure, the company's success has been dramatic, in terms both of eamings and appreciation in the value of shares since an initial public offering in 1992.

274. See supra notes $265-66$ and accompanying text.

275. See ROBERT FRANK, PASSIONS WITHIN REASON (1988) (developing and providing considerable empirical evidence for the "commitment model," as opposed to the "rational-actor model," of human behavior, according to which individuals judge one another's loyalty and honesty according to observable actions and cues, which in turn depend in part upon unobservable behavior); id. at 17 ("Whether people honor their agreements when they expect to interact repeatedly with us is obviously important. But in much of life, we are concemed instead with how they behave either in fleeting encounters or in ones where their behavior simply cannot be observed. These cases, after all, are the ones that seriously test a person's character. In them, an honest action will be one that, by definition, requires personal sacrifice."); id. at 18 ("The direction of causality between character and behavior ... runs both ways. Character influences behavior, of course. But behavior also influences character. Despite our obvious capacities for selfdeception and rationalization, few people can maintain a predisposition to behave honestly while at the same time frequently engaging in transparently opportunistic behavior."); id. ("If character traits like honesty are observable in a person, an honest person will benefit by being able to solve important commitment problems. He will be trustworthy in situations where the purely self-interested person would not, and will therefore be much sought after as a partner in situations that require trust.").

276. See Romano, supra note 17 , at 130 (reviewing evidence that bad managements tend to be replaced and good managements tend to keep their jobs). 
courts to distinguish those circumstances from circumstances in which a target board 'loyally grants a compensatory lockup. Indeed, as can be observed in Figure 7 above, a lockup could preclude lower valuing bidders while providing the recipient less than its expectancy. ${ }^{277}$ This exemplifies another way in which a lockup with adverse ex post implications for bidders may have offsetting, beneficial ex ante implications for target shareholders. ${ }^{278}$ A rule that invalidated such lockups, assuming that such lockups could be identified, might well punish loyal arrangements more than disloyal arrangements.

Finally, if the relevant players know one another's valuations of the target (or who among them most highly values the target), then even in an auction regime that invalidates all lockups, the highest valuing bidder will be able to win the target at some bid less than the reservation price of the second-highest valuing bidder (i.e., $V_{3}$ ). Assuming that there is some cost, call it " $Z$," to each prospective bidder of participating in an auction, a rational bidder would not offer an initial bid, much less continue bidding up to its reservation price, once it recognized that it was competing against a higher valuing bidder. The expected value of the lower valuing bidder's continued participation, $-Z$, is negative. Consequently, the higher valuing bidder will win an auction simply by entering it. There is no need to actually outbid its competitors; a wellknown willingness to do so suffices. Thus, the highest valuing bidder can, even in an auction regime, win the target at the lowest bid necessary to induce shareholders to tender, which, as one defender of an auction regime has noted, could be "very low ... indeed."279 Notice that the failure to raise the share price to the reservation price of the second-highest valuing bidder is at bottom a consequence, not of lockups, but of the fact that the players are well informed. In sum, whatever the auction context, there seems to be little basis for invalidating lockups, even with respect to the goal of maximizing target shareholder returns.

\section{The Benefits of Lockups}

Part III has thus far sought to raise doubts about the practically uncontested view that lockups can serve the disloyal interests of target boards. In this Section, we shift from defense to offense and examine the possible benefits of lockups to target shareholders. Our analysis proceeds by comparing two benchmark regimes: the first, an auctioneering or non-enforcement regime, is equivalent to our current de facto regime, in which a corporate board

277. See supra text accompanying notes 116-26 (summarizing Ayres' view that lockups providing no more than a bidder's expectancy are not suspect from an ex ante perspective); infra Part III.C.2 (providing a number of ex ante justifications even for greater-than-expectancy lockups).

278. See supra Part II.C.3.

279. Bebchuk, supra note 10 , at 253. 
intending to sell its firm is required to sell the target in an open auction; ${ }^{280}$ the second is our proposed full-enforcement regime, in which target boards could, at any point before or during an auction, grant an enforceable lockup of any size. The purpose of our comparison is to determine whether and under what circumstances a loyal target board might grant a lockup rather than hold an open auction. Ultimately, this Section significantly strengthens the case for unlocking lockups: Our analysis suggest that lockups can serve-indeed, may be critically important to-the loyal interests of target boards. Initially, however, this Section will examine several incomplete, but commonly offered, justifications for lockups.

\section{Conventional Justifications}

As we have already observed, legal scholars accept that lockups can serve loyal ends. Indeed, it is with lockups' potential benefits in mind that courts appear to have gone out of their way to avoid explicitly disallowing all lockups. ${ }^{281}$ Nevertheless, no scholar or court has dedicated much more than passing reference to possible justifications for lockups, and those justifications that have been offered seem underdeveloped, if not fundamentally flawed.

Lockups are most often justified as a means of inducing an otherwise reluctant bidder to enter an auction contest. ${ }^{282}$ We argue below that lockups can have that desirable effect, but courts and scholars have heretofore offered little that is illuminating about exactly why bidders require inducement. Indeed, both Bainbridge and Ayres have each included bidder inducement as one possible justification for lockups (even foreclosing lockups ${ }^{283}$ ) even though the ex post perspective that each adopts is premised on the assumption that, in the absence of lockups, the competition for targets is robust-implying few if any barriers to entry to participation in an open auction. ${ }^{284}$ The question

280. See supra Part II.B.2.

28I. See supra Part II.B.2 (describing Delaware's de facto non-enforcement regime).

282. See, e.g., authorities cited supra note 32; Note, Lock-Up Options, supra note 17, at 1076-82 (asserting that lockup arrangements are beneficial to target shareholders because they induce otherwise reluctant bidders to enter the contest as white knights, thus raising the stakes in the contest for corporate control); Note, Corporations-Mergers- "Lock-up" Enjoined Under Section 14(e) of Securities Exchange Act-Mobil Corp. v. Marathon Oil Co., 669 F.2d 366 (6th Cir. 1981), 12 SETON HALl L. REv. 881, 892 (1982) (observing that "it is only by the inclusion of a lock-up agreement that many firms will agree to assume the risk and act as a white knight, thereby allowing target management to defeat an unwanted takeover and providing target shareholders with the opportunity to sell their shares at a higher premium").

283. See supra text accompanying notes 163-65.

284. See, e.g., Bainbridge, supra note 1, at 249 ("In today's takeover environment . . . the constant threat that a third party will make a competing bid before shareholder action on the negotiated merger proposal constrains management's potential conflict of interest."). We are less certain that the threat of competition is always significant. Indeed, we suspect that, for some targets at some times, no such threat exists. In those circumstances, however, the freedom that target managements may possess to pursue their own interests to the detriment of shareholder interests is attributable not to lockups but to the absence of that disciplinary threat. Put differently, a full-enforcement regime would, in those circumstances, constrain target board disloyalty no less effectively than does a non-enforcement regime. 
arises: Why, with so much competition for targets, would a loyal board need to grant a lockup to one particular bidder to induce that bidder to compete, when other bidders would be willing to compete without such inducement?

\section{a. Compensation for Pre-Bid Investments}

The few scholars to offer some answer to that question typically indicate that lockups are needed to compensate bidders for their up-front, asset-specific investments in determining the target's value. ${ }^{285}$ For instance, Stephen Bainbridge writes:

The substantial risk of nonconsummation is especially important to the prospective acquirers, which incurs substantial up-front costs in making the initial offer. Depending on the circumstances, the initial bidder may incur significant search costs to identify an appropriate target. Once an appropriate target is identified, preparation of the offer typically requires the services of outside legal, accounting, and financial advisers. If the bidder will pay all or part of the purchase price from sources other than cash reserves, a likely scenario, the bidder also incurs commitment and other financing fees. ${ }^{286}$

More tersely, Ian Ayres explains that stock lockups "can compensate bidders for making this investment in information and more efficiently divide the risk and returns in making such investments."287 The problem with this justification is that by the time a bidder makes its bid and the target board considers whether to grant a lockup in exchange, most of those costs are already sunk. ${ }^{288}$ No loyal target would grant and no bidder could credibly demand a lockup for investments already made in identifying and evaluating the target and its value. Put differently, a lockup will not affect the bidder's willingness either to make the investments or, having made them, to pay for the target. A target should be willing to reimburse a bidder, if at all, only prior to the moment when the bidder's asset-specific investments are made. Thus, a full-enforcement regime appears to have no significant advantage over a non-

285. See generally Oliver E. Williamson, THE ECONOMic INSTITUTIONS OF CAPITALISM 30-35 (1985) (outlining the problem posed by asset-specific investments in "the world of contract").

286. Bainbridge supra note 1 , at 242 ; see also id. at 317 .

287. Ayres, supra note 9, at 698. See also Easterbrook \& Fischel, supra note 9, at 6-7 ("The size of these costs is [not known]. But one need not believe the claims of several white knights-which have maintained that they needed lock-up options on $25 \%$ or more of the target's shares or assets to make even a second bid worthwhile-in order to conclude that the costs are substantial." (emphasis and citation omitted)); Easterbrook \& Fischel, supra note 1, at 1177-79 (arguing that auctions may all but deny first bidders any return on their search costs); Johnson \& Siegel, supra note 1, at 410-11 ("Expense reimbursement is a reasonable incentive for target directors to offer reluctant bidders."); Herzel et al., supra note 17, at 153 (a bidder "may insist on a lockup as a condition for getting involved in a risky and expensive undertaking").

288. Sunk costs have already been incurred and should not affect future behavior of rational parties. See POSNER, supra note 53, at 7. 
enforcement regime in terms of providing target boards a means of compensating bidders for pre-bid investments.

\section{b. Compensation for Post-Bid Delay}

\section{i. Target-Created Delay}

Ian Ayres offers another version of the bidder-inducement justification for lockups. In his view, lockups induce not the recipient bidder but third-party bidders to enter the auction:

By persuading a bidder to hold its tender offer open for a longer time period, a target management may generate higher competing bids for the target stock. Timing is central to this story. Less time inhibits the ability of third parties to investigate and finance a competitive bid. Selling treasury shares to a bidder is a way that a target company buys time from the bidder. Although the treasury sale itself reduces the participants' reservation price of the target stock, an auction with reduced reservation prices may produce a higher bid for target shareholders than no auction at all. ${ }^{289}$

Ayres' timing story, though plausible, depends on the questionable assumption that the recipient can credibly threaten to "quickly consummate a takeover if the target fails to buy extra time" with a lockup. ${ }^{290}$ In the current auctioneering regime, however, target boards have several ways of creating delay for an auction without lowering bidders' reservation prices. To begin with, the Williams Act requires takeover bids to remain open for at least twenty business days. ${ }^{291}$ Moreover, boards can, as Ayres recognizes, adopt defenses such as poison pills prior to an offer in order to create delay once an offer has been made. ${ }^{292}$ Similarly, target boards can employ litigation as a time-buying, auction-creating device. ${ }^{293}$ Finally, the duty of care requirements announced in Smith v. Van Gorkom ${ }^{294}$ have the effect of giving-and may

289. Ayres, supra note 9, at 696 (footnote omitted). But cf. Schwartz, supra note 10, at 238 (arguing that lockups may discourage third-party bidders from making asset-specific investments in target search).

290. Ayres, supra note 9, at 697-98.

291. 17 C.F.R. § 240.14e-1 (1993).

292. Ayres, supra note 9, at 698; see Grundfest, supra note 5, at 858 ("Poison pills are common among publicly traded firms, and a firm without a pill can quickly adopt one should the need arise."); see also Jeffrey G. Macintosh, The Poison Pill: A Noxious Nostrum for Canadian Shareholders, 15 CAN. BUS. L.J. 276 (1989) (describing use of poison pills).

293. See Roberta Romano, Competition for Corporate Charters and the Lessons of Takeover Statutes, 61 FORDHAM L. REV. 843, 851 (1993); see, e.g., Seaboard World Airlines, Inc. v. Tiger Int'l., Inc., 600 F.2d 355, 365 (2d Cir. 1979) ("The present litigation, in our view, is merely a last minute effort to delay and thereby defeat the tender offer by resort to the Williams Act."). See generally Gregg A. Jarrell, The Wealth Effects of Litigation by Targets: Do Interests Diverge in a Merger?, 28 J.L. \& ECON. 151 (1985) (arguing that target boards employ litigation for precisely that purpose).

294. 488 A.2d 858 (Del. 1985). 
well have been intended to give-the target board the time needed to create an auction. ${ }^{295}$ Because of the superior substitutes available to target boards, our proposed full-enforcement regime seems no better than the current nonenforcement regime in terms of providing target boards the ability to induce third-party bidders to compete for the target. ${ }^{296}$

\section{ii. Inherent Delay}

Other scholars have argued that loyal lockups can be used to compensate the recipient bidder for the variety of risks to which that bidder is exposed between the time it makes its bid and the time the deal closes-typically, a gap of two to four months. ${ }^{297}$ Some have suggested that during that time, a bidder has, in effect, given target shareholders a "put," 298 which can be of significant value to shareholders but which imposes significant risk on the bidder. $^{299}$ The target shareholders have the right, but not the obligation, to sell their shares at the bid price. The recipient bidder must keep its offer open for an extended period of time-a period in which any number of things might happen in the economy, in the target's industry, or in the target itself to lower the value of the target. Also during that time, the bidder may have to forgo other takeover opportunities. ${ }^{300}$ Lockups, according to this view, compensate the recipient for being committed to a transaction that, before the deal is closed, becomes unattractive.

There are problems with this general justification of lockups too, however. To begin with, it is not clear that lockups eliminate those risks. That is, it is

295. See generally Jonathan R. Macey \& Geoffrey P. Miller, Trans Union Reconsidered, 98 YALE L.J. 127 (1988). The Delaware Supreme Court's recent holding in Cede \& Co. v. Technicolor, Inc., Nos. 336 \& 337, 1993 Del. LEXIS 398 (Del. Oct. 22, 1993), arguably has the same effect. See also Paramount Communications, Inc. v. QVC Network, Inc., 1994 WL 30181 (Del. Feb. 4, 1994).

296. In any event, if we are correct that the costs of resale are not transaction prohibitive, see supra Part III.A.2.a, then a target board's inability to create an auction affects only shareholder revenues, not allocative efficiency. That is, even in the absence of an auction, the target will end up in the hands of the bidder that values it the most.

297. See Bainbridge, supra note 1, at 241. While Ayres' argument was that bidders may require compensation in exchange for the risks arising from board-created delay, this related justification assumes that bidders may require compensation for the risk arising from the delay that is inherent in the takeover process.

298. A put option, very basically, gives the holder the right to sell a specified number of shares of stock at a stated price on or before a specified time. See generally STEPHEN A. ROSS ET AL., CORPORATE FINANCE 614 (3d ed. 1988).

299. The Delaware chancery court has characterized a stock lockup in this way:

[I]n the event of a higher bid being made for the stock of Trans Union, the Pritzkers would be compensated [by the treasury shares] to some extent by having issued what amounted to a "put" to Trans Union, in that during the 90 to 120 days required to gain approval of the proposed merger, the Pritzkers would be contractually obligated to consummate the proposed merger, while Trans Union would remain free to accept a better offer.

Smith v. Pritzker, No. 6342, 1982 WL 8774, at *3 (Del. Ch. July 6, 1982), rev'd sub nom. Smith v. Van Gorkom, 488 A.2d 858 (Del. 1985).

300. See Bainbridge, supra note 1 , at 242 . In the recent battle over Paramount, Viacom argued that it had demanded the lockup as compensation for its lost opportunities. 
not clear how a lockup compensates a bidder for the risk that a pending takeover may lose some of its appeal. Moreover, if a bidder did want to eliminate those risks it could do so directly by, for instance, incorporating more specified provisions in the merger agreement that adjusted for those risks or by simply including a financing condition in its offer. ${ }^{301}$ Financing conditions take the teeth out of merger agreements because both parties are virtually free to walk away from the deal. That may be an unsatisfactory solution, however, if the parties would prefer to be able to enter into a binding lockup agreement. It is still unclear, however, why they would value that ability. That is, even after examining several of the most common justifications for lockups, the benefits of a full-enforcement regime over our current auctioneering regime are anything but evident.

\section{c. Compensation for Target Breach}

None of the above justifications begins to resolve the tension in the arguments of those who, on one hand, would enforce some lockups on the basis that lockups may be a loyal board's best means of inducing bidder participation and who, on the other hand, would enjoin some lockups on the grounds that lockups can be used as a potent tool for disloyally discouraging bidders who are eager to compete without the inducement of a lockup. If the costs and risks facing the nonrecipient bidders are so slight that they will not dampen the bidding contest, then it is not at all clear why the costs and risks facing the recipient bidder would be so much greater as to justify a lockup. One frequent defense of lockups potentially resolves that tension: Lockups address the risk created by the existence of so many potential competitors-that is, the risk of target breach. While Ayres seems to imply that justification of lockups, ${ }^{302}$ Bainbridge makes the point more explicitly:

Another party may approach the target board with an alternative, presumably higher-priced, acquisition proposal; indeed, target management might initiate negotiations with a second party before presenting the initial bid to the shareholders. Alternatively, a competing bidder may directly present its proposal to target shareholders by making a tender offer for their shares. ${ }^{303}$

Thus, the risk of target breach seems at first blush to be an extremely strong candidate for explaining why loyal boards might grant a lockup. After all, that is the risk that legal economists most commonly argue contract damage

301. See supra note 52 (describing how financing conditions permit bidders, in effect, to abandon transactions without liability). Indeed, there may be a causal connection between the increased use of financing conditions in recent years and the fact that courts have been unwilling to enforce lockups.

302. See supra text accompanying note 287.

303. Bainbridge, supra note 1 , at $241-42$. 
remedies are intended to address. ${ }^{304}$ Somewhat surprisingly, however, even the target-breach justification for lockups fails to provide a strong basis for preferring a full-enforcement regime over our current non-enforcement regime.

To see why, consider the following hypothetical (which we will build on in Part III.C.2, below). ${ }^{305}$ Suppose that "Target"306 would be willing to sell to any bidder who paid more than $\$ 150$ per share for all of Target's shares. Suppose further that Bidder 1, who values the target at $\$ 200$ per share, enters into a merger agreement with Target to pay $\$ 175$ per share at some point in the future for all shares. ${ }^{307}$ Now suppose that there exists a third-party bidder (Bidder 3) who may bid for Target some amount equal to its reservation price, $V_{3}$, before the merger agreement between Bidder 1 and Target is consummated. ${ }^{308}$ Although Target and Bidder 1 are aware of that possibility, they do not know $V_{3}$ at the time they negotiate their merger agreement. They do know, however, that $V_{3}$ will be one of the following: $\$ 150, \$ 180$, or $\$ 250$ per share. Assume also that all parties are risk-neutral-that is, they care only about expected values of possible gains or losses, not the magnitude of those gains or losses. ${ }^{309}$ Assume finally that the costs of contracting between Bidder 1 and Bidder 3 and of renegotiating between Bidder 1 and Target are prohibitively high. ${ }^{310}$

Now suppose that Target and Bidder 1 write a merger agreement containing the following lockup provision: If Target sells to Bidder 3 , then Target must pay Bidder $1 \$ 25$ per share. It is easy to see that this hypothetical contract is efficient. A contract is efficient (or "mutually optimal") if the terms of that contract maximize the total gains to trade between the contracting parties. ${ }^{311}$ The only contingency relevant to the gains to trade between Target

304. See, e.g., POLINSKY, supra note 239, at chs. 5 \& 8; Steven Shavell, Damage Measures for Breach of Contract, 11 BELL J. ECON. 466 (1980); Shavell, supra note 177.

305. The hypothetical is adapted from a simple but illuminating hypothetical developed by Professor Polinsky. See POLINSKY, supra note 239, at 28-38.

306. For simplicity, and because we are assuming throughout this Section that target managers are loyal to shareholder interests, we shall treat the target board and shareholders as if they were a single entity, "Target."

307. For simplicity, we will assume initially that Target and Bidder 1 share the belief that an open auction for Target has an expected value of $\$ 175$. Below we relax that assumption and allow for the possibility that Target and Bidder 1 have different beliefs about the expected outcome in an open auction. See infra Part III.C.2.a.

308. We make the last assumption, that Bidder 3 will bid its reservation price, for the sake of simplicity. It is simpler than assuming that Bidder 3 is the higher valuing bidder of two third-party bidders who bid up to $V_{3}$ in an English auction. In any event, we relax the assumption below. See infra Part III.C.2.c.

309. We relax that assumption in Part III.C.2.b infra.

310. That assumption, too, we relax below. See infra text accompanying notes 321-25.

311. POLINSKY, supra note 239 , at $27 \mathrm{n} .16$ (an efficient contract would maximize the parties' joint benefits net of their joint costs); Kornhauser, supra note 53, at 697; Steven Shavell, Principles of Economic Analysis of Law, ch.9, 3 (unpublished manuscript, on file with authors) (a "mutually optimal" contract "arrang[es] matters so as to maximize the joint net value of things to the contracting parties, the value to either net of any costs either bears." (emphasis in original)). We assume that there are no externalities associated with these contracts. 
and Bidder 1 is whether Target should sell to Bidder 3. Notice that any time Target sells to Bidder 1, the gains to trade will be $\$ 50$. Ignoring the lockup provision for the moment, the potential gains to trade will vary between Target and Bidder 3 depending on the value of $V_{3}$. If $V_{3}$ equals $\$ 150$, there will be no gains. If $V_{3}$ equals $\$ 180$, the total gains will be $\$ 30$, which is still less than they would be if Target sold to Bidder 1 . Finally, if $V_{3}$ equals $\$ 250$, total gains will rise to $\$ 100$. Thus, a mutually optimal contract would lead Target to sell to Bidder 3 if $V_{3}$ equals $\$ 250$ but not if $V_{3}$ equals $\$ 150$ or $\$ 1800^{312}$

Under our assumptions, Target's promise to pay $\$ 25$ to Bidder 1 if it sells to Bidder 3 is efficient because it ensures that the total gains are maximized between Target and Bidder 1 . To see why that is true, notice that $\$ 25$ is the amount Bidder 1 expects to profit in the event its agreement to purchase Target is consummated-that is, $\$ 25$ is Bidder 1's "expectancy." As a general matter, if a breaching seller must pay the initial buyer her expectancy, the seller will breach only when doing so is efficient. ${ }^{313}$ In our hypothetical, this can be seen by the fact that, as compared to selling to Bidder 1, Target would experience a net loss of $\$ 50$ if it sold to Bidder 3 when $V_{3}$ equalled $\$ 150$, and a net loss of $\$ 20$, when $V_{3}$ equalled $\$ 180$ (remember, Target would have to pay $\$ 25$ to Bidder 1 if Target sells to Bidder 3). Target would experience a net gain of $\$ 50$ if it sold to Bidder 3 when $V_{3}$ equalled $\$ 250$ (Target's gains would increase from $\$ 25$ to $\$ 75$ ). Thus, as legal economists have concluded, so long as a seller is required to pay a buyer's expectancy in the event of seller breach (i.e., "expectation damages"314) efficient breach will occur even in the absence of "explicit contract provisions governing breach."

It is for this reason that in most contract settings, courts typically award expectation damages to the nonbreaching party when breach occurs. ${ }^{316}$ If damages are set too high (or low), under this model, breach will not be mutually optimal. As Professor Polinsky explains,

the expectation remedy is the only remedy that creates efficient incentives with respect to breaches of contracts. This is because the

312. We are able to ignore gains to Bidder 3 by assuming that Bidder 3 bids its valuation, $V_{3}$.

313. Polinsky, supra note 239, at 31; Charles J. Goetz \& Robert E. Scott, Liquidated Damages, Penalties and the Just Compensation Principle: Some Notes on an Enforcement Model and a Theory of Efficient Breach, 77 CoLUM. L. REv. 554, 558 (1977); Shavell, supra note 311, at ch. 9, 20-21.

314. Note that a lockup that provides the recipient bidder its expectancy is equivalent to what Ayres deems an "auction insurance lockup" and what we refer to as an "expectancy lockup." See supra text accompanying note 121 .

315. POLINSKY, supra note 239, at 31-32. See generally Shavell, supra note 177. Note that Bidder l's bid depends in part on the amount paid by Target to Bidder 1 if the target sells to Bidder 3-in our example, the amount is $\$ 25$. Bidder 1 would always prefer to receive more and Target would always prefer to pay less in the event that Target sells to Bidder 3 . Bidder 1 would thus be willing to pay, and Target would require, an increase in Bidder l's bid in exchange for an increase in the contract remedy. See POLINSKY, supra note 239 , at 30 .

316. See Shavell, supra note 311 , at ch. $9,20-21$. Thus, in many contract settings a buyer and seller can forgo the inconvenience of writing a fully specified contract, as well as the trouble of specifying the remedy that would ensure efficient breach. 
expectation remedy forces the breaching party to pay in damages the value of the good to the breached-against party. If another buyer values the good more than this, then it is efficient for that buyer to have the good. Given the expectation measure of damages, the seller will have an incentive to breach in order to obtain the higher offer. If another buyer values the good less than the original buyer, a breach is not efficient and the expectation remedy will appropriately discourage breaches. Any other measure of damages for breach of contract generally will be inefficient. ${ }^{317}$

It is now easy to see that Target and Bidder 1 are each worse off where, as in our auctioneering regime, lockups are unenforceable. Target will breach the agreement whenever Bidder 3's bid exceeds Bidder 1's bid. To enjoy $\$ 30$ instead of $\$ 25$ of gains, Target will breach even when $V_{3}$ equals $\$ 180$. That breach is not mutually optimal because, although Target increases its take by $\$ 5$, Bidder 1 is out $\$ 25$. In a full enforcement regime, Bidder 1's willingness to pay Target some amount more than $\$ 5$ but less than $\$ 25$ not to breach when $V_{3}$ equals $\$ 180$ would be reflected in Bidder 1's bid. That is, Bidder 1's higher bid in a full enforcement regime would be more attractive to Target than Target's ability to breach in a non-enforcement regime. ${ }^{318}$ In this way, both parties suffer a loss any time their contract fails to maximize joint gains to trade. ${ }^{319}$ Because, by assumption, Bidder 1 and Target cannot write a mutually optimal contract in an auctioneering regime, the risk of target breach appears to provide a plausible justification for enforcing lockups. ${ }^{320}$

That justification depends on the assumptions that contracting costs between Bidder 1 and Bidder 3 and that the renegotiation costs between Bidder 1 and Target are prohibitively high. Assuming prohibitively high contracting costs, if the merger agreement contained a lockup worth $\$ 100$ (instead of $\$ 25$ ), Target would not breach under any circumstances, and hence the contract would fail to maximize the joint benefits of Target and Bidder 1. More generally, where lockups promise recipients more than their expectation damages, breach will occur too rarely. As we already argued at some length, however, those assumptions seem to be without basis. ${ }^{321}$ Absent those assumptions, the case we just made for lockups as a means of ensuring

317. POLINSKY, supra note 239 , at 33-34.

318. If that were not the case, Target would, in a full-enforcement regime, simply maintain its right to sell to Bidder 3 when $V$, equals $\$ 180$.

319. Cf. Shavell, supra note 311 , at ch. 10,27 ("Anything that raises the value of a contract to the two parties, that increases the net pie to be shared by them, will conduce to contract formation; anything that reduces the size of the pie may mean that a contract will not be formed when it could have been.").

320. As we argued earlier, courts are ill-equipped to measure a bidder's expectancy. See supra text accompanying notes 131-47. That shortcoming justifies the inclusion of specified-damages clauses.

321. See supra Part III.A.2.a-b. Although those subsections examine only the former assumption, we know of no reason to suspect that the renegotiation costs between Bidder 1 and Target would be any larger than the contracting costs between Bidder 3 and Bidder 1 . If we are wrong, and renegotiation costs between Bidder I and Target are prohibitively high, then our case for lockups would be strengthened. See infra note 324. 
mutually optimal breach unravels. However, if one assumes, more realistically, that Bidder 1 and Bidder 3 can negotiate their own deal at little cost, then mutual optimality will obtain even with that larger lockup. ${ }^{322}$ Bidder 3 will pay Bidder $1 \$ 250$ for Target. Target will thus gain $\$ 25$ from its sale to Bidder 1 and Bidder 1 will gain \$75-the difference between what it paid for Target and what Bidder 3 paid. The result is mutually optimal because the total gains shared between Target and Bidder 1 are the same as they were in our original example, $\$ 100 .^{323}$ As this hypothetical helps to make clear, any damages remedy exceeding the bidder's expectation damages will be mutually optimal.

Suppose now that the damages remedy were $\$ 0$ and that $V_{3}$ equalled $\$ 180^{324}$ In that situation, Bidder 1 would still win Target by renegotiating-that is, by increasing its bid to $\$ 180$ (or slightly more). Total gains would be maximized between Target and Bidder 1 at $\$ 50$. In sum, when realistic assumptions are made about the ability of bidders to contract with one another and of the recipient bidder to renegotiate with the target, any damages measure will ensure that only mutually optimal breach occurs. ${ }^{325}$ Thus, the goal of ensuring mutually optimal target breach plays no obvious role in justifying lockups.

So here we are. The longstanding set of uncontroverted justifications for lockups seem unable to bear the weight that has been placed on them. Our original question remains: Why would a full-enforcement regime be superior to a non-enforcement regime? The remainder of this Section provides two sets of preliminary answers to that question. The first set views the relationship between Target and Bidder 1 as analogous to that of a seller and buyer in a more typical contracting context and suggests how lockups can be mutually optimal. The second set views the relationship between Target and Bidder 1 as analogous to that of a seller and buyer in an English auction and suggests how enforceable lockups might be employed to increase target returns above what they would otherwise be in the absence of enforceable lockups. Although

322. This is a brief version of the argument we made in Part III.A.2, supra, that target boards are unable to foreclose higher valuing bidders.

323. The fact that gains may be allocated differently between Target and Bidder 1 will be taken into account in Bidder 1's bid. See supra note 315.

324. If, for some reason, renegotiation costs between Bidder 1 and Target were prohibitively high, then there would be a target-breach justification for lockups. Absent a lockup, Bidder 1 would still end up with Target, but it would have to purchase Target from Bidder 3 for some amount greater than $\$ 180$. To be concrete, suppose that Bidder I paid Bidder $3 \$ 200$ for the target. In that case, Target would enjoy $\$ 30$ of gain, but Bidder 1 would enjoy no net gain. Target and Bidder 1 would have sacrificed $\$ 20$ of joint gain in conveying Target to Bidder 3. A lockup will be mutually optimal if it guarantees that Target goes directly to Bidder I whenever $V_{1}$ is greater than $V_{3}$. Thus, a lockup providing Bidder 1 its expectation measure or any remedy measure greater than that will be mutually optimal. As Steven Shavell has summarized this point, such a damage remedy would be mutually optimal because "anytime [Bidder 3] would bid more than [Bidder 1]'s valuation, [Bidder 1] would sell to him; thus [Bidder 1] and [Target] as a pair would not lose the opportunity to sell to [Bidder 3]." Shavell, supra note 311, at ch. 10, 22 .

325. This result is simply another application of the Coase Theorem. See supra note 186 and accompanying text. Price will reflect allocation of opportunities to sell to a higher valuing bidder; total gains will be the same. 
both sets of answers involve increasing target returns, the former set does so by increasing the total gains to trade between buyer and seller, and the latter does so by allocating a greater share of those total gains to the target.

\section{Maximizing Joint Gains To Trade}

\section{a. Differing Estimates of Auction Outcome}

By relaxing our starting assumption that Bidder 1 and Target share in the belief that an open auction for Target would lead to an expected bid price of $\$ 175^{326}$ and allowing for the realistic possibility that the parties' beliefs may differ, one possible justification for lockups comes immediately into focus. The more pessimistic that Target is as to the expected outcome of an open auction, relative to Bidder 1 , the stronger will be that Target's incentive to negotiate directly with Bidder 1 . Suppose, for example, that Bidder 1 estimates that the expected outcome of an auction would be $\$ 233$ (an eighty percent chance that $V_{3}$ equals $\$ 250$, plus a ten percent chance that $V_{3}$ equals $\$ 180$ or $\$ 150$ ). Because Bidder 1's reservation price is $\$ 200$, Bidder 1 would prefer to purchase the Target outside an auction for some amount less than $\$ 200$ to competing for Target in an open auction. Suppose that Target estimates the expected auction outcome to be $\$ 163$ (an eighty percent chance that $V_{3}$ equals $\$ 150$ and a ten percent chance that $V_{3}$ equals $\$ 180$ or $\$ 250$ ). Under those circumstances, there is a large range of bids that Bidder 1 is willing to make and that Target would be happy to accept. For instance, if Bidder 1 bid $\$ 175$ per share, then, from an ex ante perspective, Target is better off accepting this bid because its expected premium is raised from $\$ 13$ (i.e., $\$ 163-\$ 150$ ) to $\$ 25$ per share. ${ }^{327}$ In our non-enforcement regime, however, this sort of contracting will never take place. Suppose, for example, that, after Bidder 1 contracts to acquire Target at $\$ 175$ per share, Bidder 3 offers, say, $\$ 180$ per share. Target will opportunistically sell to Bidder 3 . Recognizing this possibility, Bidder 1 will not enter into this sort of contract unless Target can offer some credible commitment. If Target is unable to commit to a particular bidder via a lockup, as it is under our current non-enforcement regime, Target will suffer, because it will be unable to enter into contracts that, from an ex ante perspective, maximize the expected bid price for the Target. A bidder would raise its bid initially in exchange for a lockup only if it trusts ccurts to enforce the lockup, as it would in a full-enforcement regime.

326. See supra note 307.

327. In the extreme, Bidder 1 may feel certain that $V_{3}=\$ 250$, and Target may feel certain that $V_{3}=$ $\$ 150$. Under those circumstances, Bidder 1 would believe itself certain to lose an auction, but would be willing to raise its bid in exchange for some profits for losing. Indeed, Bidder 1 would bid over its reservation price, so long as it did not bid so high as to foreclose Bidder 3. Target, of course, would simply be trying to maximize Bidder l's bid and would be unconcerned about foreclosure. 


\section{b. Risk Aversion}

To see another possible explanation for lockups (even greater-thanexpectation lockups), it is necessary to relax our starting assumption that the players are all risk-neutral. ${ }^{328}$ If either or both the target or bidder is risk averse, a lockup may have important efficiency consequences as a mechanism for allocating risk. ${ }^{329}$ Establishing the mutually optimal size of lockups is simple if one is concerned only with risk allocation.

Suppose first that Bidder 1 is risk-averse, and Target is risk-neutral. Efficient risk allocation is achieved very simply with a lockup that promises Bidder 1 his expectancy. With such a lockup, Bidder 1 gets its expectancy, $\$ 25$, regardless of the value of $V_{3}$, and Target bears all the risk. If risk preferences are reversed such that Target is risk-averse and Bidder 1 is riskneutral, then Bidder 1 should bear all the risk and Target, none of it. That is easily accomplished by a lockup that pays Bidder $1 \$ 75$ per share (the difference between Bidder 1's bid and Bidder 3's higher bid) in the event of Target breach. With that lockup, Target would gain $\$ 25$ no matter who won the auction. Only Bidder 1's profits are uncertain-either $\$ 25$ if $V_{3}$ equals $\$ 150$ or $\$ 75$ if $V_{3}$ equals $\$ 250$. Notice that such a lockup would be all but fully foreclosing. Finally, suppose the bidder and target are both risk-averse. The risk should then be shared between them in accordance with the relative intensity of their aversions. A lockup somewhere between the two extremes already described-that is, greater than $\$ 25$ but less than $\$ 75$-would achieve that goal.

In sum, if at least one party is averse to risk, efficient lockups will ensure that Bidder 1 receives at least expectation damages. ${ }^{330}$ To see this point graphically, refer to Figure 9. Lockup 1 gives all the risk to Target and none to Bidder 1; Lockup 2 reverses that allocation of risk; Lockup 3, falling somewhere within the cross-hatched section splits the risk between Target and Bidder 1.331

328. Managers may be justifiably risk-averse because of the sizeable firm-specific investment of human capital that they make in their firms. See John C. Coffee, Shareholders Versus Manager: The Strain in the Corporate Web, 85 MICH. L. REV. 1, 105 (1986); David N. Haddock et al., Property Rights in Assets and Resistance to Tender Offers, 73 VA. L. REV. 701, 715 n.31 (1987); Steven Shavell, Risk Sharing and Incentives in the Principal and Agent Relationship, 10 BELL J. ECON. 55 (1979); Alan J. Marcus, Risk Sharing and the Theory of the Firm, 13 BELL J. ECON. 369 (1982).

329. "Risk aversion is likely to be important when the item being sold is valuable so that the bids are large relative to any bidder's assets." McAfee \& McMillan, supra note 270 , at 726 . Other than a lockup agreement, the only method by which a bidder might insure itself from this type of risk is to acquire a "toehold position" in the target company and sell it at a profit if another bidder is successful. With regard to the larger target companies, however, toeholds are of little value, because a mere $\$ 15$ million position requires a filing under Hart-Scott, at which point the market is likely to react, making her purchases of shares more expensive. Hart-Scott-Rodino Antitrust Improvements Act of 1976, 15 U.S.C. \$ 18a(3) (1994).

330. See PoLINSKY, supra note 239, at 62. See generally A. Mitchell Polinsky, Risk Sharing Through Breach of Contract Remedies, 12 J. LEGAL STUD. 427 (1983).

331. The arguments that lockups can be jointly optimal because of differing estimates of an auction outcome or because of a party's aversion to risk are analogous to arguments made on behalf of settlement 


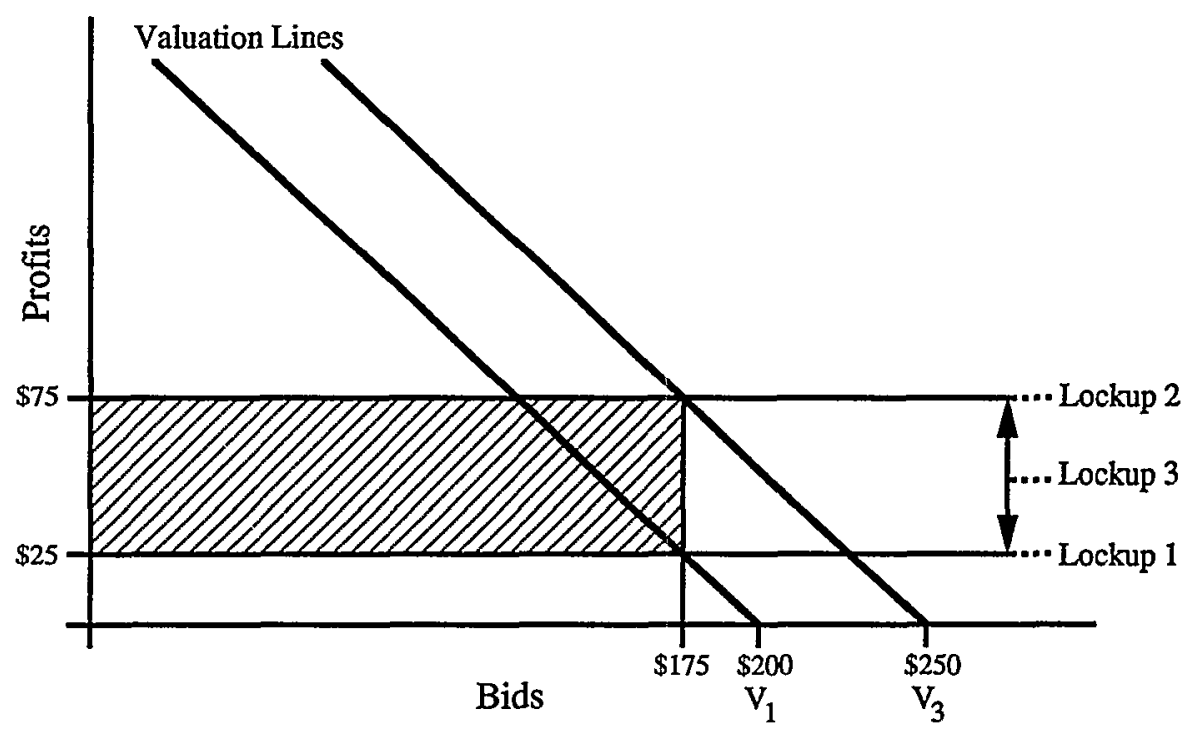

FIGURE 9. Allocating Risk with Lockups

\section{c. Collusive Contracting}

Another justification for greater-than-expectation lockups becomes evident once we relax our initial assumption that Bidder 3's bid is exogenous to the negotiations between Target and Bidder 1. That is, our example has thus far assumed for simplicity that Bidder 3 would offer its reservation price, $V_{3}$. That assumption is unrealistic, however. In our current auction regime, Bidder 3 would know Bidder 1's bid of $\$ 175$ and would offer some amount above $\$ 175$ but less than $V_{3}{ }^{332}$ Bidder 3's incentive, of course, is to pay as little as possible for Target in order to maximize its own surplus. In such circumstances, however, Target and Bidder 1 may have the ability and certainly have the incentive to extract for themselves some or all of what would be Bidder 3's surplus. With the aid of a lockup, Target and Bidder 1 can jointly determine the minimum amount Bidder 3 must pay, to Target in the form of a bid and to Bidder 1 in accordance with the lockup, to win Target. If Target grants a lockup to Bidder 1 and then agrees to sell to Bidder 3, Bidder 3 must not only outbid Bidder 1, it must also bear the cost of the

between litigants. See, e.g., Steven Shavell, Suit, Settlement, and Trial, 11 J. LEGAL STUD. 55, 62-63 (1982). For an introduction to that literature, see generally id.; POLINSKY, supra note 239, at ch.14; POSNER, supra note 53, at 554-60. Settlements are also sometimes justified as a means of saving the litigants substantial litigation costs. See PoLINSKY, supra note 239, at 109. That justification, too, applies to lockups in light of the costs of holding auctions. See infra note 352.

332. Our simplifying assumption does not affect our conclusions above. See supra note 308. 
lockup paid to Bidder 1 as a consequence of Target's breach. Such a lockup would benefit both Target and Bidder 1. To see why, suppose that Target and Bidder 1 know that $V_{3}$ equals $\$ 250 .{ }^{333}$ In the absence of a lockup, bidding for Target would escalate between Bidder 1 and Bidder 3 up to $\$ 200$ (i.e., $V_{l}$ ), at which point Bidder 1 would bow out of the auction contest and Bidder 3 would emerge the winner. In that scenario, Bidder 1 and Target would together gain $\$ 50$ worth of profit, all of which would go to Target, and Bidder 3 would enjoy $\$ 50$ of buyer's surplus. Target and Bidder could maximize the joint values of their agreement by, in effect, colluding to extract from Bidder 3 all of that buyer's surplus with a $\$ 50$ lockup. There are any number of arrangements that Target and Bidder 1 might make to accomplish that goal, but one possible candidate is depicted in Figure 10.

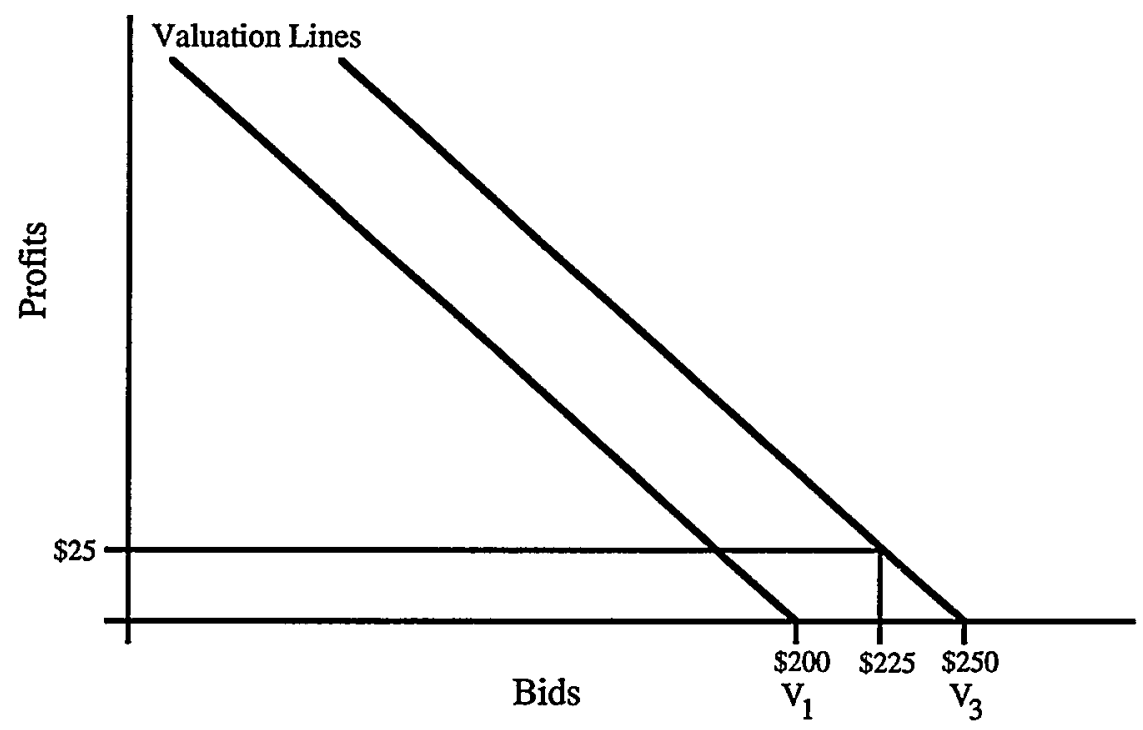

FIGURE 10. A Collusive Lockup

If, as Figure 10 implies, Target and Bidder agree to split the $\$ 50$ of collusive gains evenly, then Bidder 1 would need to increase its bid by $\$ 25$ above its reservation price, to $\$ 225$ per share, and Target would need to grant Bidder 1 a lockup worth $\$ 25$ per share. Target would receive $\$ 75$ of seller's surplus per share, and Bidder 1 would receive $\$ 25$ of profit per share. With that sort of agreement, Target and Bidder 1 can, acting jointly as a price-discriminating

333. We make this assumption for simplicity. More generally, the mere possibility of a higher valuing bidder may create an opportunity for collusion between Target and Bidder 1 that we describe below. See authorities cited infra note 335 . 
monopolist would, take for themselves surplus that would otherwise go to Bidder 3. Although any such lockup would provide greater-than-expectation damages to Bidder $1,^{334}$ any such lockup would also be mutually optimal between Target and Bidder 1 and would not impede allocative efficiency. ${ }^{335}$

\section{d. Encouraging Search}

Most efficiency-minded corporate law scholars agree that a robust market for corporate control is the best mechanism for disciplining corporate managers, who otherwise have incentives to pursue their own interests at the expense of shareholder interests, ${ }^{336}$ and that target boards should therefore be prohibited from defending against any takeover bid. Beyond that, however, scholars strongly disagree over how best to nurture the takeover market. One camp argues that managements are prompted to act as loyal agents by the threat of being taken over; if they behave disloyally, the firm's stock price will fall to some bargain level. The more potential bidders there are searching for such bargains, the greater will be the threat of takeover and, in turn, the more loyal corporate management will be. ${ }^{337}$ According to this view, the law should minimize the premiums paid to target shareholders in order to encourage bidders to invest in target search. More specifically, several scholars have argued that the Williams Act should be repealed and that target boards should be prohibited from conducting auctions or otherwise interfering with bidders' takeover efforts. ${ }^{338} \mathrm{~A}$ second camp has advanced the opposite conclusion. Professors Bebchuk and Gilson, for example, have each raised serious questions about whether or to what extent increasing prospective bidder search for targets is encouraged by a policy that would minimize takeover premiums. ${ }^{339}$ Scholars have also pointed out that creating rules that permit target boards to extract more of the takeover gains (or, in other words, to increase takeover premiums) reduces agency costs by creating an incentive for managements to make value-maximizing investments in the firm and increases the prospective target's investment in bidder search. ${ }^{340}$ Thus, while all agree

334. Shavell, supra note 311 , at ch. 10, 20; see also id. at 21 ("It is true that with the measure of damages exceeding the expectation measure, there will be breach less often than mutually optimal. However, it will be beneficial to the parties to trade off this disadvantage to gain some advantage in extracting a higher price in the event of breach.").

335. For similar, more general treatments of this sort of collusion between a buyer and seller, see generally Philippe Aghion \& Patrick Bolton, Contracts as a Barrier to Entry, 77 AM. ECON. REV. 388, 389 (1987); Shavell, supra note 311 , at ch. 10, 20-21.

336. See, e.g., EASTERBROOK \& FISCHEL, supra note 5, at 163-209.

337. See generally Daines \& Hanson, supra note 207, at 609.

338. See, e.g., Easterbrook \& Fischel, supra note 9, at 17; Schwartz, supra note 10, at 230. $52-62$.

339. See, e.g., Bebchuk, supra note 9, at 30-38; Gilson, Seeking Competitive Bids, supra note 190, at

340. Bebchuk, supra note 9, at 38; Haddock et al., supra note 328, at 709-10. Still others have criticized the premium-minimization proposals on the altemative ground that shareholders have not, but could easily, obtain such a result via contract (i.e., corporate charters). See id. at 704; Daines \& Hanson, 
that search is important and to be encouraged, substantial disagreement exists over exactly who, between potential bidders and potential targets, should receive the encouragement.

With respect to encouraging search, our proposed full enforcement regime is unambiguously preferable to the current non-enforcement regime, because it would increase potential bidders' and potential targets' expected returns to search. Under the current regime, a bidder has very little incentive to invest in discovering desirable takeover opportunities. After all, if the target board does not want to sell to the bidder, it can simply reject the bidder's offer (so long as it rejects all bidders' offers). ${ }^{341}$ On the other hand, if the board wants to sell to the bidder, the board is obligated to hold an open auction. ${ }^{342}$ Auctions eliminate some or all of the bidder's potential returns to search, because other bidders, after free-riding on the initial bidder's investments in search, will likely bid up the price of the target toward or beyond the initial bidder's reservation price. ${ }^{343}$ Under our proposed full-enforcement regime, however, a potential bidder would enjoy greater expected returns to search simply because the bidder can expect to receive a lockup in those circumstances in which the target board would like to sell to the bidder. ${ }^{344}$

Similarly, moving toward a full-enforcement regime would increase potential targets' incentives to search. That is true, in part, for the obvious reason that enforcing lockups would-as this Section of the Article is intended to demonstrate-increase the expected returns of target shareholders, and, hence, would also increase the benefits of target investment in bidder search. The second and less obvious reason is that lockups might be employed to reduce the cost of search. Very simply, Bidder 1 may be better able to search for a higher valuing Bidder 3 or to extract a higher bid from Bidder 3 than would Target where, for example, Bidder 1 has superior information about the market or is in a better bargaining position than Target. If so, Target can employ foreclosing lockups as a means of hiring Bidder 1 as, in essence, a sales agent. By awarding Bidder 1 a greater-than-expectation lockup, Target gives Bidder

supra note 207 , at $584-600$.

341. See supra notes 5-6 and accompanying text.

342. See supra note 7 and accompanying text.

343. See Easterbrook \& Fischel, supra note 9, at 3-7; Schwartz, supra note 10, at 232-40.

344. It might be argued that a full-enforcement regime might reduce a bidder's incentive to search because it might permit a target board to grant a lockup to a second bidder as a way of selectively defending against an initial bidder's offer. Recall, however, that under the current regime a target board can simply reject the initial bidder's offer. Put differently, a full enforcement regime will not discourage bidder search any more than it has already been discouraged in the current regime.

The original debate over whether the law should strive to give potential bidders or potential targets the greater incentive to search took place on the now-unrealistic assumption that target boards could not erect defenses of any sort. Under that assumption, the question of whether a full-enforcement regime would, on net, increase potential bidders' incentive to search is analytically ambiguous: enforceable lockups could either increase or decrease potential bidders' expected returns to search, depending on the circumstances. In any event, the question is now purely academic and outside the scope of this Article. 
1 an incentive to sell to Bidder $3 .^{345}$ And by awarding Bidder 1 a stock lockup, the value of which increases as bidding increases, Target gives Bidder 1 an incentive to sell to Bidder 3 for as high a bid as possible. ${ }^{346}$

\section{Replicating the Ideal Auction}

As the previous section reveals, there are a variety of means by which a loyal board might grant a lockup, even a greater-than-expectation lockup, to extract a higher bid from the recipient bidder. Put differently, lockups, like contractual remedies more generally, can assist a target and recipient bidder in making mutually optimal commitments. Dropping now the contract-remedy perspective and adopting instead an auction perspective, this Section provides further support for the claim that lockups can serve the interest of target shareholders: An auctioneering regime contains several potential flaws, which loyal boards might, if permitted, attempt to overcome with lockups. To understand the potential failings of an auctioneering regime, one should recognize that an important advantage of such a regime, according to both scholars and courts, is its effect on target revenues. ${ }^{347}$ That is, because takeover auctions are similar to English auctions, ${ }^{348}$ they ensure that the winning bid will equal (or slightly exceed) the reservation price of the secondhighest valuing bidder-we shall refer to that bid as the "ideal auction price." 349 This section shows how a full enforcement regime can be superior to an auctioneering regime in terms of ensuring that target shareholders receive an ideal auction price. ${ }^{350}$

We have already noted that when, in an independent-private-values auction, bidders know one another's actual valuations or, at least, who among all bidders has the highest valuation, then the highest valuing bidder can win the target at some price below the ideal auction price. ${ }^{351}$ That will be true whenever there are costs to participating in an auction. ${ }^{352}$ In a full

345. Cf. Ayres, supra note 9, at 698; Shavell, supra note 311 , at ch. 10,22 \& n.19.

346. In this way, a loyal target board may be able to compensate a recipient bidder for being a “"stalking horse" for an 'auction contest'." Smith v. Van Gorkom, 488 A.2d 858, at 866 (Del. 1988).

347. See, e.g., Paramount Communications, Inc. v. QVC Network, Inc., 1994 WL 30181 (Del. Feb. 4, 1994); Revlon, 506 A.2d at 182; Bebchuk, supra note 10, at 255.

348. Michael J. Fishman, A Theory of Preemptive Takeover Bidding, 19 RAND J. ECON. 88, 89 (1988) ("Takeover bidding contests are similar to English auctions. Bidders submit successively higher bids until a high bid stands.").

349. McAfee \& McMillan, supra note 270 , at 707 ("When will the bidders stop bidding up the price in the English auction? The second-last bidder will drop out of the bidding as soon as the price exceeds his own valuation of the item. Thus the highest valuation individual wins the bidding and pays a price equal to the valuation of his last remaining rival.").

350. In addition to maximizing target shareholder retums, the ideal auction price may serve important efficiency goals. See generally Bebchuk, supra note 10.

351. See supra text accompanying note 279.

352. These costs can include the time and expense to management of due diligence, the professional fees paid to investment bankers, lawyers, and accountants, and the commitment fees needed for each round of financing. See Louis Lowenstein, Management Buyouts, 35 CoLUM. L. REV. 730, 758, 779 (discussing 
enforcement regime, however, that problem would not emerge. The target board would grant to another bidder a lockup that compensates the bidder for the costs of entering (and ultimately losing) the auction and that forces the initial bidder to raise its bid to an acceptable level. Indeed, the very threat of such a lockup may well deter the initial bidder from making a low bid in the first place and thus save the board the trouble of having to induce another bidder into the contest. ${ }^{353}$

We saw an analogous problem in common-value auctions (which some scholars have argued make up the majority of takeover auctions). ${ }^{354}$ All potential bidders will be deterred from bidding for a target if just one bidder has made an initial bid, no matter its size. The logic is straightforward: If a second bidder enters, that bidder will either win the target at its reservation price or lose; in either case, the costs of having participated in the auction will be lost without any offsetting gains. Given those prospects, potential bidders will not enter the contest and the initial bidder will walk away with the target without having paid the common value. Again, in the context of common-value auctions, and in precisely the same way, target boards can employ lockups to attract other bidders to enter the contest (or the threat of lockups to ensure that the initial bidder pays the common value). ${ }^{355}$

Finally, independent-private-value auctions have a particular problem in the takeover context, which stems from the fact that the auction procedure is controlled by the target board. More specifically, a target board has the ability to conduct an auction in order to identify the highest valuing bidder and then to negotiate with that bidder the price and terms of the deal. Those "postauction negotiations create the possibility of ex post opportunism and consequent ex ante welfare losses." ${ }^{356}$ Because the winning bidder's bid will "usually . . . be below his own valuation of the item[,] [t] he successful bidder earns some economic rent in spite of the monopoly power of the seller."357 But, knowing that the winning bidder will likely bid less than its actual valuation, a target board can opportunistically extract part of the bidder's surplus by refusing to sell to that bidder at the given bid. ${ }^{358}$ If the target

some of those costs)

353. The same justification for lockups may apply even in a world in which bidders do not have information about other bidders' valuations: It has been argued that an initial bidder who is not the highest valuing bidder can nevertheless use a "preemptive bid" to signal to other potential bidders a high valuation and thereby deter competition. See Cramton \& Schwartz, supra note 2, at 42-43. See generally Fishman, supra note 348 . Again, revenue-maximizing target boards might employ lockups to induce higher valuing bidders to enter the contest and outbid the initial bidder. See Cramton \& Schwartz, supra note 2, at 43. This is also analogous to our justification of lockups when one bidder has promised to ratchet its bid upward in response to any competing bidder's bid. See supra note 51 and accompanying text.

354. See supra text accompanying notes 265-66.

355. See Cramton \& Schwartz, supra note 2, at 33.

356. Id. at 41.

357. McAfee \& McMillan, supra note 270, at 707.

358. Such post-auction negotiations may be quite common. For example, after a 12-hour negotiating session, Alfred Checchi's numored offer price of $\$ 115-\$ 120$ per share for NWA, parent of Northwest 
board does this, the bidder stands to lose the investment it made in the auction process, which is now a sunk cost. Whether the bidder ultimately wins or loses, the target's ex post negotiations could well drive the bidder's overall profits to some amount less than zero:

If bidders anticipate this board strategy . . . the auction could unravel; no one would enter. Every potential bidder would reason that either it will have the highest valuation among those that enter, in which case it will win the auction but could earn negative returns on net, or it will not have the highest valuation and so will lose, in which case its entry costs will have been wasted. Deterring entry is inefficient so postauction negotiations produce ex ante welfare losses. ${ }^{359}$

A target could commit not to engage in this sort of exploitation and, hence, eliminate those welfare losses by promising the auction participants that it will grant a lockup to the auction winner. The lockup would protect the auction winner against an opportunistic threat of breach by the target and thus against the prospect of earning negative returns from participating in the auction. ${ }^{360}$ Again, therefore, lockups enable target boards to overcome the failing of an auctioneering regime. Ironically, the Delaware courts not only invalidate lockups that could be used to eliminate such opportunistic behavior, they have arguably mandated that boards adopt such a strategy. ${ }^{361}$

\section{Summary}

Accepting the conventional view that lockups can be desirable or undesirable from an efficiency and/or revenue-maximization perspective, Part II concluded with the observation that no rule or standard has been, or is likely to be, devised that is, or would be, of practical use in assisting courts to distinguish desirable from undesirable lockups. Offering a new view of lockups, Part III has provided arguments suggesting two general conclusions. First, contrary to the received wisdom, lockups are unlikely to frustrate significantly the goals of efficiency or revenue maximization. Second, lockups

\footnotetext{
Airlines, was finalized at $\$ 121$ per share. It appears that although Checchi's $\$ 115-\$ 120$ bid "won" the auction, NWA was able to force his bid to \$121. See Randall Smith \& Judith Valente, NWA Agrees to a $\$ 3.65$ Billion Takeover by Group Led by Investor Alfred Checchi; But Northwest Air Parent Has Backup Plan that Would Add Less Debt, WALL ST. J., June 20, 1989. For another such example, see In re RJR Nabisco, 57 U.S.L.W. 2482 (Del. Ch. Jan. 25, 1989).

359. Cramton \& Schwartz, supra note 2, at 41; see also McAfee \& McMillan, supra note 270, at 703 ("[I]t would be in the seller's ex post interest to renege on his promise to charge a price equal to the highest bid; instead, he could offer the item at a price higher than the highest bid and yet slightly less than the highest valuation, and it would be in the interest of the bidder who has that valuation to accept this offer. Of course, if the bidders knew in advance that the seller might renege on his announced policy, they would not bid as hypothesized.").

360. Cramton \& Schwartz, supra note 2 , at 42.

361. Cf. Paramount Communications, Inc. v. QVC Network, Inc., 1994 WL 30181 (Del. Feb. 4, 1994).
} 
can actually promote either or both of those goals, though in ways that courts and scholars have not previously understood.

\section{CONCLUSION}

At the outset of this Article, we summarized the well-accepted view that target boards, whether they agree to sell or resist selling their firms, are apt to be acting contrary to the interests of target shareholders. One lesson that should be drawn from our analysis is that the conventional wisdom may only be half right. More specifically, regardless of whether a target board grants a lockup, the board loses much of its control over whether and to what extent the target's incumbent management will be retained when the board agrees to sell the target. In contrast, when a board rejects all bidders, the board retains control. Most legal scholars do not distinguish lockups from other "defensive tactics" used to defend against all potential bidders. By lumping lockups and, say, poison pills together, those scholars have erroneously remained suspicious of lockups. ${ }^{362}$ While Delaware courts sometimes draw a distinction between a target board's efforts to reject all bidders and its efforts via a lockup to reject all but one, their approach of being highly deferential with respect to the former but nondeferential with respect to the latter is fundamentally flawed. If courts are going to selectively defer to target-board decisionmaking in the takeover context, they have especially good reason to do so only after a target board has decided to sell. That conclusion is confirmed by a brief review of the most well known Delaware takeover cases.

Taking market price as our measure, it might be argued that Delaware courts are validating those board decisions that are most damaging to shareholders and invalidating those that are valuable to shareholders. ${ }^{363}$ For instance, in Paramount $I$ the Delaware Supreme Court deferred to the business judgment of the Time board, whose rejection of the Paramount offer cost the shareholders a premium of $\$ 75$ per share. Less than two years after that $\$ 200$ offer, the price of Time stock had sunk to below $\$ 70$; and only within the last year has the price recovered to above $\$ 100 .^{364}$ On the other hand, Delaware

362. Cf. RONALD J. GILSON, The LAW AND FinANCE OF CORPORATE ACQuismons 838 (1986); Bainbridge, supra note 1, at 293 n.232 ("When a competing bidder objects to a lockup, it is essentially making the same claims which a hostile bidder makes against takeover defensive tactics. In either case, the bidder complains that the target has erected an impermissible barrier to its offer. Not surprisingly judicial analysis of lockups has frequently paralleled the rules governing takeover defenses."); Coffee, supra note 218, at 1528; Note, Lock-Up Options, supra note 17, at 1068 (calling lockups a "defensive tactic").

363. We are assuming here that the premium over market price provides a good measure of the benefits of a bidder's offer. Cf. EASTERBROOK \& FISCHEL, supra note 5, at 19 ("[M]arkets transmit the value of information through price, which is more 'informed' than any single participant in the market."). See generally Sanford J. Grossman and Joseph E. Stiglitz, Information and Competitive Price Systems, 66 AM. ECON. REV. 246 (1976); Robert E. Verrecchia, Consensus Beliefs, Information Acquisition, and Market Information Efficiency, 70 AM. ECON. REV. 874 (1980).

364. See Thomas L. Hazen, The Corporate Persona, Contract (and Market) Failure, and Moral Values, 69 N.C. L. REV. 273, 291 n.105, $292-93$ (describing how Time shareholders lost out by not being 
courts overturned the board decisions in Revlon, ${ }^{365}$ Macmillan, ${ }^{366}$ Holly Farms, ${ }^{367}$ and Paramount II. ${ }^{368}$ In Revlon, the offending board decision was held to lock out a higher bid of only $\$ .75$ per share; in Macmillan, $\$ .20$ per share; in Holly Farms, between $\$ 0$ and $\$ 4.25$ per share; and in Paramount, roughly $\$ 5.00$ per share. The Delaware Supreme Court has also held target boards personally liable, in part because of lockup agreements thought to indicate the boards' lack of due care. For example, in Van Gorkom, the board's "gross negligence" actually yielded shareholders a premium of almost $50 \%{ }^{369}$ And, very recently, in Technicolor the court held that a duty-of-care claim was not subject to proof of the resultant injury or loss-fortunately for the plaintiff, who as a shareholder was due a premium from the "breach" of about $200 \%{ }^{370}$ In these two cases, the court deemed the boards to have breached their duties of care to the shareholders by entering into uncontested merger agreements, even though the agreements in both instances would have netted shareholders huge gains. In sum, most investors, in a world with no judicial interference, would probably prefer to have been a shareholder of Revlon, Macmillan, Holly Farms, Paramount, Trans Union (the target company in Van Gorkom), or Technicolor at the moment of the offending board decision than of Time Inc. at the moment of the "non-offending" one. ${ }^{371}$

To put the same point in slightly broader terms, Delaware courts appear to intervene dramatically in board-room decision making when a board decides to sell a firm to a specific bidder at a substantial premium, but show nearcomplete restraint when a board decides (1) to reject any and all takeover offers, regardless of the premium being offered, (2) to authorize a "merger of equals" transaction in which their company merges with another and the shareholders receive no premium for their stock (and perhaps even receive less than market value for their stock), or (3) to purchase another firm at substantial premium (and perhaps overpaying). The "inherent" conflicts of interest which Delaware courts claim to find so troubling in the takeover context would appear to be most severe in the last three settings and, as this Article has argued, virtually non-existent in the first. If judicial restraint is appropriate in the last three settings, in which a board is rejecting or paying a substantial

able to tender to Paramount); Coffee, supra note 218, at 1540 (same).

365. Revlon Inc. v. MacAndrews \& Forbes Holdings, Inc., 506 A.2d 173 (Del. 1986).

366. Mills Acquisition Co. v. Macmillan, Inc., 559 A.2d 1261, 1288 (Del. 1988).

367. In re Holly Farms Shareholders Litig., 1988 Fed. Sec. L. Rep. (CCH) II 94,181 (Del. Ch. Dec. $30,1988)$.

368. QVC Network, Inc. v. Paramount Communications, Inc., 635 A.2d 1245 (Del. Ch. 1993).

369. Smith v. Van Gorkom, 488 A.2d 858 (Del. 1985).

370. Cede \& Co. v. Technicolor, Inc., Nos. 336 \& 337, 1993 Del. LEXIS 398 (Del. Oct. 22, 1993).

371. Cf. ClARK, supra note 1, at 532 ("Shareholders are ... usually delighted to hear that their company has become the target of the tender offer."). 
shareholder premium, ${ }^{372}$ it is surely appropriate in the first setting, in which a board of directors is accepting a substantial shareholder premium. ${ }^{373}$

Almost all of our arguments in favor of unlocking lockups do not depend on, and have been made without reference to, the fact that Delaware courts are tremendously deferential to boards outside of the sale context. ${ }^{374}$ If that deference can be taken as given, our call for a full-enforcement regime becomes quite compelling, even if one rejects all of our arguments (in Part III.A-B, supra) that lockups are unlikely to frustrate the goals of corporate law. The reason is straightforward: Because the underlying concern about lockups is that managements will employ them disloyally to protect their incumbency, and because managements have at their disposal a number of alternative means

372. Of course, it is an open question whether judicial restraint is appropriate in those settings. One of us has recently argued, along with Robert Daines, that target boards should have the power to resist a bidder if, but only if, they can guarantee target shareholders a return equivalent to what shareholders could obtain if they were freely permitted to tender their shares to the bidder at the bid price. See generally Daines \& Hanson, supra note 207. That such guarantees might be feasible finds some support in the very recent battle over Paramount. There, Viacom gained its ultimate advantage over rival bidder QVC by including in its bid a so-called "contingent value right" similar to the sort of guarantee (or "passivity pill") that Daines and Hanson describe. Id. at 623-24. As far as we can tell, this is the first time a guarantee of this nature has been granted to target shareholders. For a description of a previous flawed effort, see Daines \& Hanson, supra note 207 , at 623 n.214. For a description of the device employed by Viacom, and how it came to be, see John Greenwald, The Deal that Forced Diller To Fold, TIME, Feb. 28, 1994, at 50; John Cassidy, Paramount Victory Leaves Viacom Exposed, SundAY Times, Feb. 20, 1994.

373. We know of no corporate charter or state statute that limits (or, even prior to Revlon, limited) a board's ability to grant lockups. See Daines \& Hanson, supra note 207, at 584, 587-88; $c f$. Bainbridge, supra note 1, at $255 \& \mathrm{n} .49$ ("Modern corporation codes are generally silent on the effect of a merger agreement pending shareholder approval."); $i d$. at 258-59 ("Modern corporation statutes give target boards broad authority to determine whether to merge the firm and to select a merger partner. The initial decision to enter a negotiated merger transaction is thus reserved to the board's collective business judgment, shareholders having no statutory power to initiate merger negotiations. The board also has sole power to negotiate the terms on which the merger will take place and to enter a definitive merger agreement embodying its decisions. Shareholders have no statutory right to amend or veto specific provisions, their role typically being limited to approving or disapproving the merger agreement as a whole, with most statutes requiring approval by only a majority of the outstanding shares." (footnotes omitted)). Easterbrook and Fischel have argued that (1) the terms of corporate charters are likely to be efficient, and that (2) silence in a corporate charter implies shareholder acquiescence. EASTERBROOK \& FISCHEL, supra note 5, at 7,21-22. If one accepts Easterbrook and Fischel's "efficiency thesis," then one might also conclude that the absence of statutory or charter limitations on lockups is evidence that shareholders prefer a full enforcement regime to any of its alternatives. That argument gains plausibility if one believes, as some scholars seem to, that desirable limitations on a board's discretion with respect to lockups could be easily achieved via "contractual" terms in the corporate charter. See supra text accompanying notes 92-97 (summarizing Bainbridge's "bright-line" rule); Ayres, supra note 9, at 684 (Ayres characterizes his rule as "straightforward" and "practical"). Put more succinctly, if undesirable lockups are as easy to identify as Bainbridge and Ayres suggest, then why do we not see that standard emerging via corporate charters or state incorporation statutes? This fact should give pause to any court or commentator who would disallow some or all lockups on the grounds that they are counter to shareholder interests. But see generally Daines \& Hanson, supra note 207 (offering general critique of Easterbrook and Fischel's "efficiency thesis").

Outside of the courts, then, the only source of lockup restrictions comes from the two major exchanges and NASDAQ, which set a 20\% cap on the number of shares management may issue without shareholder approval (for a lockup or any other reason), but does not limit the value of the lockup itself and has no effect whatsoever on non-stock lockups. NYSE Regulation 312.03(c). AMEX Regulation 713(a). NASD Manual Sec 5(d). Thus, most if not all of the stock lockups which the courts have chosen to invalidate are permissible under the rules of the exchanges and NASDAQ, institutions which one might presumably consider "shareholder friendly." See also supra note 24.

374. But see supra notes 224 \& 334. 
to that disloyal end, the current approach of enjoining lockups does not serve its intended purpose. In sum, because boards do not need lockups in order to satisfy their own interests in job security, but may need lockups in order to satisfy shareholder interests, unlocking lockups can have only desirable consequences.

We have argued that courts should enforce all lockups, no matter their terms, because lockups may be effective as instruments of loyal boards, but are probably ineffective as instruments of disloyal boards. But there may be a more important reason for unlocking lockups: Doing so may reduce the agency costs of corporate ownership outside of the corporate control context. We share the view of most corporate law scholars that a robust takeover market is the most potent deterrent to disloyal managerial decisionmaking. ${ }^{375}$ Unfortunately, however, that market had until very recently largely evaporated and remains anemic, in part because of the evolution of substantive corporate law in Delaware. One means of fostering the slightly reinvigorated takeover market may be for courts to begin enforcing all lockups. Such a regime would circumvent some of the costly litigation that frequently occurs under the current regime over the enforceability of lockups. ${ }^{376}$ The uncertainty and administrative costs of control transactions might therefore be substantially reduced. Moreover, if lockups were enforced, target boards could use them to serve a variety of possible transaction-facilitating purposes, such as redistributing some of the risks that currently may discourage the initiation and consummation of control transactions. ${ }^{377}$ Those who believe, as we do, that a robust takeover market helps reduce agency costs resulting from the corporate condition-that is, from what Berle and Means first termed "the separation of ownership and control"378 - should thus find timely and attractive our policy proposal.

375. See, e.g., Gilson, supra note 1 , at $841-45$.

376. See Bainbridge, supra note 1, at 283 (judicial review of lockups is "a costly, dangerous, but essentially meaningless, ritual"); Johnson \& Siegel, supra note 1, at 374-75; cf. John C. Coffee, Jr., Regulating the Market for Corporate Control: A Critical Assessment of the Tender Offer's Role in Corporate Governance, 84 COLUM. L. REV. 1145, 1264-65 (1984) (describing the benefits of certainty in the takeover context); Daniel R. Fischel, The Business Judgment Rule and the Trans Union Case, 40 Bus. LAw. 1437, 1453 (1985); Fraidin \& Franco, supra note 23 (noting the deterrent effect of the threat of litigation on the takeover market). See also QVC Network:, Inc. v. Paramount Communications, Inc., 635 A.2d 1245 (Del. Ch. 1993).

377. See supra Part III.C.; Bainbridge, supra note 1, at 282 . "The present uncertainty as to the validity of . . lock-ups produces important social costs. If uncertainty causes parties to not enter into exclusivity provisions or lock-ups when the provisions, in fact, would benefit shareholders, socially desirable behavior is deterred. . . . Courts can alleviate this problem, at least in part, by adopting bright-line standards that clearly define when target boards can validly enter exclusivity provisions."). $c f$. Herzel, et al., supra note 17, at 151 ("It is quite clear that lock-ups have profound implications for corporation law.").

378. ADOLF A. BERLE \& GARDINER C. MEANS, THE MODERN CORPORATION AND PRIVATE PROPERTY 5 (1932) ("It is precisely this separation of control from ownership which makes possible tremendous aggregations of property."); see Michael C. Jensen \& William H. Meckling, Theory of the Firm: Managerial Behavior, Agency Costs and Ownership Structure, 3 J. FiN. ECON. 305, 327 (1976) (noting "the costs of "separation of ownership and control"). 